\title{
The contribution of the Irish soldier to the British Army during the Peninsula campaign $1808-1814$
}

\author{
James Deery
}

The majority of the historiography concerning the Irish contribution to the British army during their campaign on the Iberian Peninsula (1808 -1814) has focused on the Irish regiments and their service with Wellington in Portugal, Spain and France. While the significance of research into these regiments is undeniable it has unintentionally resulted in an under appreciation of the true extent of the Irish soldier's contribution. The purpose of this paper is to add to the existing historiography by examining the wider Irish contribution in order to arrive at an empirical based assessment as to the criticality of the Irish soldier to Wellington's victory during the Peninsula war.

The majority of Irish soldiers who served in the Peninsula did so in English and Scottish infantry regiments. Their abilities and crucially their integration into the British army were key success factors for Wellington during the Peninsula campaign. An examination of how this was achieved forms a key part of this paper which finds that the capabilities of the Irish soldier and the British army organisational structure and system mutually supported each other. Furthermore, the Irish officer's contribution has only been assessed based on individual accounts and narratives in the absence of any in-depth evaluation of their actual numbers. With over 30 per cent of Wellington's officers being Irish an analysis of their levels of command was undertaken to demonstrate their significance to the overall conduct and operation of the Peninsula army. To fully understand the Irish soldier's contribution an assessment of their combat effectiveness building on the preceding quantitative findings and utilising modern concepts of combat motivation and behaviours was undertaken.

The findings indicate that while the Irish soldier's contribution was much wider and central to victory in 1814 than is generally appreciated or understood, the British army of the period recognised its importance and, despite popular misperceptions, did not at an institutional level seek to discriminate against the Irish soldier. The paper concludes that Irish soldiers were of critical importance to British victory not only in terms of their numbers but also due to their successful integration into the wider British army outside of Irish regiments, their presence in large numbers at all levels of command and their overall combat effectiveness. Without this contribution it can be argued that British victory would not have been achieved in the Peninsula.

Note: this paper is based on an MA thesis completed in the Department of History at Maynooth University (Ireland) and submitted for examination in 2018. 


\section{INTRODUCTION}

The Peninsular campaign (1808 - 1814) emerged from inauspicious beginnings to become the cornerstone of British strategy against Napoleonic France. ${ }^{1}$ By placing 'boots on the ground' Britain was able to effectively project its power onto continental Europe, ultimately gaining a seat at the Congress of Vienna. This would not have been achieved if its contribution had been restricted to purely maritime and financial considerations. ${ }^{2}$ By April 1814 Wellington had through a combination of political diplomacy, skilful generalship and sound military administration routed the French armies from the Iberian Peninsula. The 'machine' that allowed him to achieve such a decisive victory was his famed Peninsular army. ${ }^{3}$

In 1808 such a 'machine' was not standing by ready to wage war with Napoleonic France. Wellington introduced many advanced military practices as he sought a qualitative advantage over the numerical superiority of the French. Innovations such as the autonomous divisional structure, use of light infantry and a tactical system matched to the capabilities of his army were all key success factors and could not have been implemented without an effective command and staff system. Throughout the campaign Wellington ensured he had proficient officers leading units comprised of well disciplined, skilled and proficient soldiers. It is on these officers and men, specifically those of Irish birth that this paper will focus.

As Karsten observed, the Irish soldier in the British army remains an understudied figure despite the fact that the British army actively recruited within Ireland for all regiments. ${ }^{4}$ By 1806 there was an increase in the number of Irish soldiers enlisting in non-Irish regiments which peaked in 1813 with estimates ranging from $30-40$ per cent as the British undertook sustained military operations in the Peninsula. ${ }^{5}$ Although the contribution of these men has been acknowledged in a number of historical works the focus has mainly been on the Irish regiments of Wellington's army. ${ }^{6}$ Consideration of the wider Irish involvement tends to be presented in overall numerical terms without serious analysis of other key factors relating to their service. ${ }^{7}$ Even less effort has been expended on examining Irish officers, placing the Irish contribution firmly at the lower end of the value chain. This one-dimensional perspective underrates the Irish soldier's importance to the British army and Britain's wider strategy for the defeat of Napoleonic France.

The aim of this paper is to assess the importance of Irish soldiers to the British army during the Peninsular war (1808 - 1814). The paper will examine the contribution of Irish soldiers using statistical analysis of demographical details from War Office records. This will be used to determine key factors such enlistment and promotion trends, discipline patterns and other relevant service particulars of Irish soldiers. The paper will also examine the lesser understood contribution of Irish officers with specific reference to their numbers, levels of command and perspectives as to their cultural identity within the British army. Again, statistical analysis of service details from primary sources supported by personal accounts will be used. Finally, to understand the full extent of Irish soldiers' contribution, an evaluation of their combat effectiveness will be undertaken. A framework using criteria developed from studies of modern combat effectiveness will be used, supported by statistical evidence and qualitative information from primary sources of the period. It is intended that a more evidence-based assessment of the Irish soldier's 
contribution and resulting importance will be added to the current historiography of this key Napoleonic campaign.

Part one of this paper examines a range of demographical details of Irish noncommissioned officers and enlisted men in the Peninsular army. As part of his research Molloy examined the extent of Irish soldiers serving in non-Irish regiments during the Waterloo campaign. ${ }^{8}$ Based on a statistical analysis of regimental description books, he found a significant portion of enlisted men and non-commissioned officers (NCOs) were Irish. ${ }^{9}$ Molloy's findings are supported by Paterson's research into the $1^{\text {st }}$ (Royal Scots) Regiment. ${ }^{10}$ Harvey also finds similar high percentages of Irish serving in English and Scottish regiments. ${ }^{11}$ This approach of examining the overall numerical contribution of Irish in non-Irish regiments has been used as a starting point in developing a deeper understanding of the wider Irish contribution.

Coss analysed the demographics and group behaviour of the British army under Wellington using a database containing the demographic details of over 7,300 British soldiers. ${ }^{12}$ While not focusing exclusively on the nationality of the soldiers Coss's work is illuminating as he provides a template for what demographical information is available from primary sources and its uses and limitations for the researcher. A similar database, focusing on one English regiment, $2 / 28^{\text {th }}$ (North Gloucestershire) Regiment, has been created containing the demographical data of approx. 700 British soldiers. ${ }^{13}$ This database was used to determine key statistical information relating to overall numbers of Irish soldiers, enlistment patterns, promotion and discipline trends.

Part one will also examine, through analysis of relevant War Office records, other important aspects of the Irish contribution. Statistical analysis by Coss, Molloy and Dunne-Lynch omits examination of the numbers of Irish men in non-Irish regiments promoted to NCO ranks in comparison to their British comrades. In addition, older historiography also portrays Irish soldiers as ill-disciplined and drunken, only effective when competently led by English officers. Sir Charles Oman, the noted military historian and chronicler of the Peninsular campaign, states that the majority of men brought before courts martial were Irish. ${ }^{14}$.More recent empirical research suggests that this view is incorrect. Divall's analysis of regimental courts martial records for the $30^{\text {th }}$

(Cambridgeshire) Regiment demonstrates that the Irish soldier was more likely to offend but not to the extent portrayed by Oman. ${ }^{15}$ It is such omissions and assumptions in the current historiography that this chapter will address using a more empirical approach to provide a deeper understanding of the actual contribution of Irish soldiers within English and Scottish regiments.

If the Irish NCO and enlisted man are understudied figures, the Irish officer is even more so. Part two will examine the contribution of Irish officers serving in the Peninsular army at divisional, brigade and regimental level and their general employment across the army. It will begin by examining the overall numbers of these officers. McGuigan, Burnham's and Reid's research provided data on Wellington's brigade and divisional commanders. ${ }^{16}$ The Annual Army List 1813 and Challis's Peninsula Roll Call were used as a starting point in identifying a sample list of officers at the selected regimental level. ${ }^{17}$ These names were cross referenced against various sources of biographical data to identify those of Irish birth. Hall's research on British officers killed and wounded during the campaign was also used to determine casualty figures among Irish officers of the selected regiment. ${ }^{18}$ 
The year 1813 has been selected as a focus for this chapter as it encompasses the pivotal Vitoria campaign by which stage Wellington had in place the key elements that formed his war winning Peninsular army.

A further key aspect explored was how these officers viewed themselves within the British army of the period. Predominately from the Protestant Ascendancy it would appear that they had closer ties with England than Irish NCOs and enlisted men.

However, recent research by Pockett and McDonnell has shown that the truth may be more nuanced and there may have been more than one identifiable Irish identity within the British army of the period. ${ }^{19}$ A related question is to what extent did their 'Irishness' contribute to the rank and file Irish soldier and his assimilation into Wellington's army. A number of these officers who served in non-Irish regiments such as $28^{\text {th }}$ (North Gloucestershire) Regiment, $32^{\text {nd }}$ (Cornwall) Regiment and the $52^{\text {nd }}$ (Oxfordshire) Light Infantry Regiment published accounts of their experiences in the Peninsula. ${ }^{20}$ These were analysed to understand their views of themselves and the Irish rank and file.

This part will also examine Catholic officers serving in Wellington's army during the period. This subject appears to have been largely ignored as an area of research. Although officially precluded from joining the army due to the requirements of the Test Acts this may not have been universally applied and examples exist of Catholic officers serving with Wellington in the Peninsula. ${ }^{21}$

A key consideration for this research, absent in the existing literature, is an evidencebased assessment of the Irish soldier's combat effectiveness. Research since the end of the Second World War has helped us to understand what motivates soldiers to perform in combat. ${ }^{22}$ Since Shils and Morris's research on the German Wehrmacht a number of concepts and methodologies have emerged which this thesis considers as part of a framework to evaluate the combat effectiveness of Irish soldiers during the Peninsular campaign.

Understanding a soldier's motivation for enlistment can be an important determinant of future combat performance. While revolutionary fervour and the new concept of the nation state were known to be important motivators for Napoleon's conscript armies the Irish soldier, similar to his English or Scottish colleague, joined predominately for economic reasons. ${ }^{23}$ However, other factors motivated him to actually remain and fight with his regiment. Combat readiness involves not only the physical components of a military unit - weapons, supplies, transport etc. but also the psychosocial characteristics of the soldiers. ${ }^{24}$ These characteristics as they relate to the Irish soldier must be understood if a meaningful evaluation of their overall contribution is to be determined. Coss in his study of the motivational factors of British soldiers in combat found that one must not look at the macro level but at the micro level and understand the small unit group dynamics within the regiment. His research and findings are again important for this thesis and will be particularly relevant for non-Irish regiments containing a high percentage of Irish soldiers.

Ben-Shalom and Benbenisty found that religion was a significant factor for Israeli soldiers coping with the stresses of combat. ${ }^{25}$ Again when considering Irish NCOs and enlisted men we find them predominantly Catholic in a Protestant military organisation and as such religion may have been an important factor in sustaining them in combat. DunneLynch also addresses other factors that are of importance when considering the combat 
effectiveness of units such as discipline, loyalty and even humour. ${ }^{26}$ The statistical findings from chapter one regarding discipline will be considered here as they relate to combat effectiveness.

In the final analysis the tactical employment of units with high numbers of Irish soldiers by senior commanders is the litmus test for considering their combat effectiveness. The selection of particular regiments to hold key or decisive terrain or to lead an attack is indicative of a commander's assessment of the combat effectiveness of that unit.

Dunne-Lynch considers the actual employment of Irish regiments in tactical situations and finds that they were generally deployed where combat was considered intense and high calibre units were required. ${ }^{27}$ An examination of the elite Light Division and in particular the $52^{\text {nd }}$ (Oxfordshire) Light Infantry Regiment was undertaken to determine the combat effectiveness of Irish soldiers within this elite formation.

As stated at the outset the current historiography of the Irish soldier's contribution outside of Wellington's Irish regiments has tended to be considered from the perspective of numbers and only at a superficial level. The paper will provide an overall assessment and conclusion as to Irish soldier's contribution to the British army during this critical campaign. By combining the quantitative findings resulting from the statistical analysis of War Office documents with the qualitative information contained in personal accounts and official reports a more evidence-based assessment can be achieved. While it is noted that first-hand accounts by serving soldiers, whether Irish or English, can be biased these may be more indicative of particular views or prejudices. If they are contrary to the evidence found through other sources, such as statistical analysis, this may suggest an under appreciation of the actual contribution of Irish soldiers to Wellington's successes or alternatively even a false perception on the part of historians of institutional discrimination against Irish soldiers within the British army of the period. The resulting findings and conclusions will add to the growing understanding and appreciation of the Irish soldier's value and importance to British strategy during the Napoleonic wars.

\section{PART ONE. THE IRISH NON-COMMISSIONED OFFICER AND ENLISTED MAN}

\section{British army recruitment and Ireland}

The precedence for recruitment of Irish soldiers into the British army can be traced back to the mid eighteenth century. ${ }^{28}$ Although precluded from bearing arms under the penal laws the British authorities did covertly turn to the manpower pool available from the Irish Catholic population in times of need as evidenced during the American War of Independence. ${ }^{29}$ The resumption of hostilities with Napoleonic France in 1803 following the breakdown of the Peace of Amiens obliged the British army to fulfil three main strategic roles (i) home defence and domestic security (ii) protection of British colonies and finally (iii) provide a force for use on continental Europe, known as the 'disposable force'.

As the disposable force grew in strategic importance greater pressure was placed on recruitment activities. Between 1792 and 1813 the British army increased from 40,000 to 250,000 men. $^{30}$ This resulted in acute manpower shortages due to continuous casualty 
levels. On average each year the army suffered in excess of 22,000 casualties. ${ }^{31}$ In 1811 , Sir Edward Littlehales, Under Secretary in the Military Department, Dublin, estimated that annual losses in excess of recruitment levels were in the order of 8,000 men. ${ }^{32}$ The resulting increase in numbers resulted in changes not only to the administration of the army but also the character and identity of the individual regiments and the army as a whole.

By the time of the Peninsular war approximately 30 per cent of British soldiers were Irish, with English and Scottish making up the remaining 53 per cent and 16 per cent respectively. ${ }^{33}$ Ireland constituted 33 per cent of the United Kingdom's total population and as such was slightly underrepresented within the army. When compared against the respective male populations for each country Ireland contributed more recruits - 2.5 soldiers per thousand males in 1809 compared to England and Scotland of between 1 and 2 soldiers per thousand males. ${ }^{34}$ Only the Scottish highlands and parts of the industrial north of England yielded similar levels.

\section{Distribution patterns of Irish soldiers across the British army}

Irish soldiers were not equally distributed across the three branches of the British army artillery, cavalry and infantry. Analysing existing research reveals a number of distinct distribution patterns for Irish soldiers.

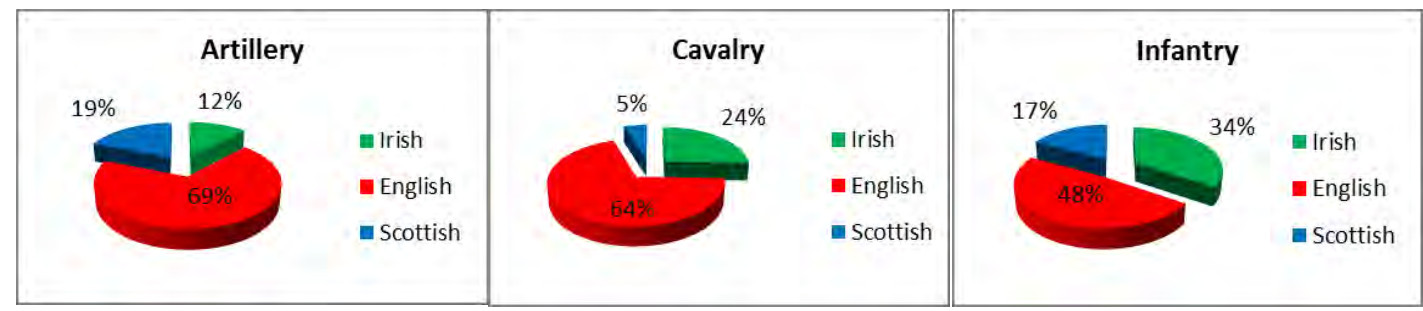

\section{Chart 1.1 Distribution patterns of Irish soldiers across the British army}

Source: E. J. Coss, All for the King's shilling - the British soldier under Wellington 1808 -1814 (Oklahoma, 2010), p. 247.

The percentage of Irish represented in the artillery arm of the British army at approximately 12 per cent was the lowest for all three service branches. ${ }^{35}$ This figure may be related to domestic security concerns of providing trained gunners to any subsequent rebellion or uprising in Ireland such as 1798 and 1803 . While the cavalry arm did not increase in size to the extent of the infantry over the course of the war it did contain a greater number of Irish soldiers at 24 per cent when compared to the artillery. ${ }^{36}$ While the same internal security reasons may have also inhibited the recruiting sergeant in enlisting Irish troopers other factors were also in operation. The cost associated with training, equipping and providing a mount for a cavalry trooper as well as the logistical difficulties in transporting cavalry overseas and in providing an adequate supply of forage once in theatre were all factors limiting the overall size of the cavalry. More specific to the Peninsular army, the nature of the terrain in Portugal and Spain inhibited the extensive use of cavalry as a battlefield tool, as discussed later.

The majority of Irish soldiers served in infantry regiments within the British army with recent research estimating that approx. 34 per cent of all infantry men were Irish. ${ }^{37}$ The 
English (including Welshmen) represented 48 per cent and the Scots 17 per cent meaning the majority of British infantry were not English. ${ }^{38}$ While Irishmen enlisted in all regular British army regiments, a number of specific non-Irish regiments contained significant percentages of Irish soldiers. Divall in her research of the $30^{\text {th }}$ (Cambridgeshire) Regiment found that 30 per cent of its ranks comprised Irish soldiers with a significant number of Irish officers ${ }^{39}$. Divall concluded based on national composition that the regiment was Anglo-Irish in its identity ${ }^{40}$. Cross referencing Linch's findings on the national composition of certain regiments against their period of service in the Peninsula we can determine a number of other Anglo or Scots - Irish units using Divall's 30 per cent criterion (see appendix 1). The classification of such units in the context of their national composition is important as none have an Irish territorial affiliation. In effect, the wider Irish contribution outside of the Irish regiments remains hidden to the student of the Peninsular campaign and indeed to some historians.

The Irish soldier was underrepresented in the Foot Guards when compared with the line or light infantry regiments. Both battalions of the $1^{\text {st }}$ Foot Guards record 4 and 1 per cent respectively in 1810 and 1811 . Interestingly these figures increased dramatically by 1815 with the $2^{\text {nd }}$ battalion having 44 per cent of its ranks filled with Irish soldiers. Both battalions of the $2^{\text {nd }}$ and $3^{\text {rd }}$ Foot Guards again record low percentages for Irish soldiers with 5 per cent in 1814 and 4 per cent in 1813 respectively. It can be assumed that given the primary function of these regiments was to act as the English sovereign's personal bodyguard there was a preference for the recruitment of English soldiers. A further factor which may also have an impact was that these regiments were not actually posted to Ireland.

Limiting statistical analysis to determining the numerical Irish contribution does not allow for a complete understanding of their contribution and experiences within the British army. By further analysing available demographical data (see appendix 2) for one specific regiment we can build a more comprehensive picture of who these men were, why they enlisted and what their experiences were within a typical English regiment. This will provide an empirical basis for an examination of the factors which facilitated their integration into Wellington's army; a key component for their resulting combat effectiveness.

\section{Case Study 1 - The Irish soldier in $2 / 28^{\text {th }}$ (North Gloucestershire) Regiment}

The $28^{\text {th }}$ (North Gloucestershire) Regiment originally formed in 1694 raised a second battalion in 1804 which was subsequently garrisoned in Ireland until 1809. To facilitate the expansion of numbers within the existing regimental structure the British army authorised regiments to raise a second and indeed additional battalions subject to sufficient recruitment levels. As these newly created battalions began to focus on recruitment their ranks included a predominance of Irish soldiers over the existing first battalion's numbers.

The $2 / 28^{\text {th }}$ (North Gloucestershire) Regiment sailed for the Peninsula in 1809 and saw action at Bussaco, Badajoz and Albuera before returning to England in 1811. On its return the battalion engaged in extensive recruitment to replace losses and send reinforcements to the $1^{\text {st }}$ battalion still serving with Wellington. The $28^{\text {th }}$ Regiment was a typical regiment 
of the line with a proud and long combat record dating back over a 100 years by the time of the Peninsula campaign.

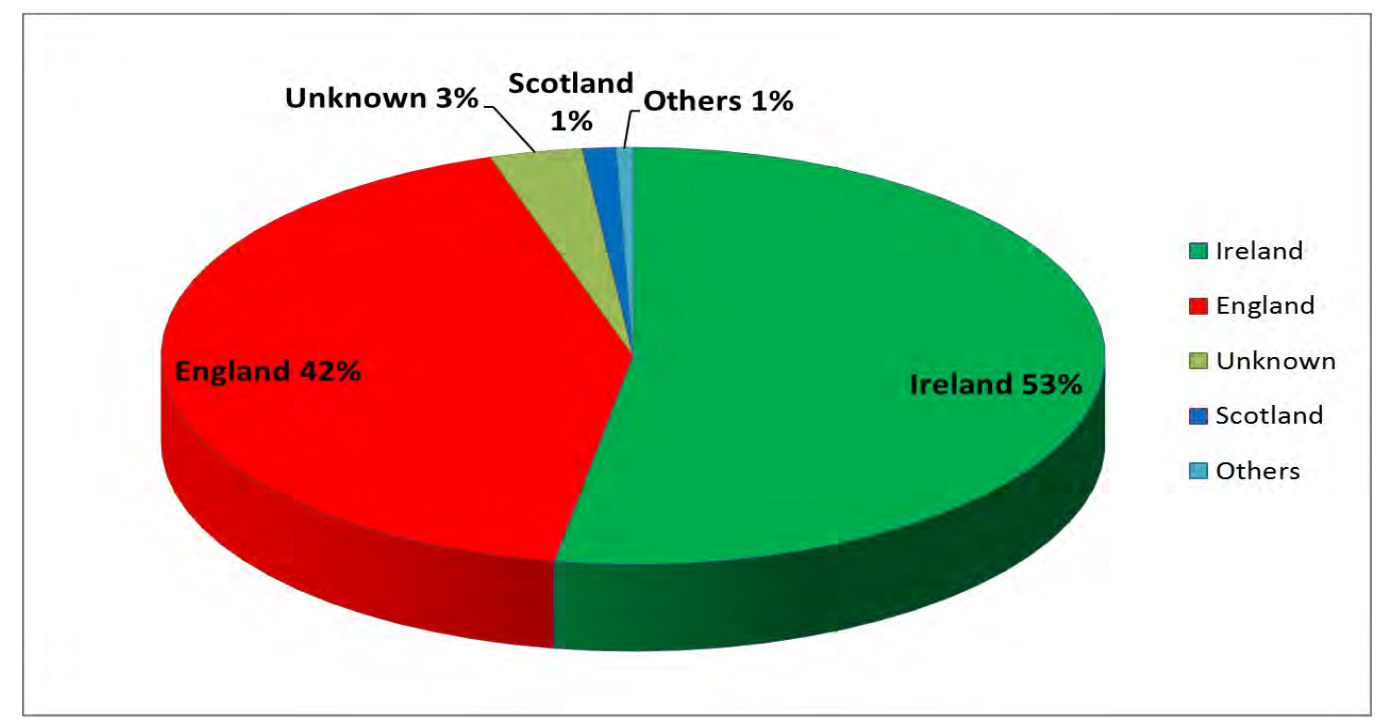

\section{Chart 1.2 National composition of $2 / 28^{\text {th }}$ (North Gloucestershire) Regiment}

Note 1: Others include one American and two Germans.

Note2: The nationality of 24 individuals could not be identified due to deterioration of the original records or information not entered.

Source: Description book $2 / 28^{\text {th }}$ (North Gloucestershire) Regiment $1812-1817$, The UK National Archives, Kew, London (hereafter (TNA, WO 25/361).

Irish soldiers comprised the largest nationality within the battalion at 53 per cent, which was slightly higher than those found by other historians for this period. Coss's study finds that the $28^{\text {th }}$ Regiment as a whole comprised 44 per cent of Irish soldiers ${ }^{41}$. The difference may be attributed to the fact that he uses a sample extract as opposed to a full population from the regimental description book. Based on the predominate nationality within the regiment the $2 / 28^{\text {th }}$ (North Gloucestershire) was more Irish than English.

\begin{tabular}{|l|c|c|c|c|}
\multicolumn{1}{|c|}{ Nationality } & Ireland & England & Other $^{\mathbf{1}}$ & Total \\
\hline Irish & 254 & 102 & 1 & $\mathbf{3 5 7}$ \\
\hline English & 111 & 172 & 2 & $\mathbf{2 8 5}$ \\
\hline Other & 3 & 6 & 2 & $\mathbf{1 1}$ \\
\hline Unknown & 6 & 2 & - & $\mathbf{8}$ \\
\hline Total & $\mathbf{3 7 4 ( 5 6 . 6 \% )}$ & $\mathbf{2 8 2 ( 4 2 . 7 \% )}$ & $\mathbf{5 ( 0 . 8 \% )}$ & $\mathbf{6 6 1 2}$ \\
\hline
\end{tabular}

Table 1.1 Place of enlistment by nationality (Ireland or England) $-2 / 28^{\text {th }}$ (North Gloucestershire) Regiment

Note 1: Other locations for enlistment include Spain, France and Scotland.

Note 2: The location of enlistment is unknown in 32 instances resulting in a survey population of 661 . 
Source: Description book $2 / 28^{\text {th }}$ (North Gloucestershire) Regiment $1812-1817$, (TNA WO 25/361).

When we analyse where the recruits, irrespective of their nationality, were enlisted we find Ireland as a recruiting area within the United Kingdom provided the greatest number of men at 56.6 per cent ( 374 recruits). What is noteworthy is that 38 per cent ( 111 men) who enlisted in Ireland were English born. While it would be expected that Irish men would enlist in England following economic migration (102 recruits), the same migration patterns appear to occur in reverse during this period with economic migration from England to Ireland.

\begin{tabular}{|ccccc|c|}
\hline Nationality & Labourer & Weaver & Skilled $^{1}$ & Other $^{2}$ & Totals \\
\hline Irish & $203(55.5 \%)$ & $55(15.0 \%)$ & $45(12.3 \%)$ & $63(17.2 \%)$ & $\begin{array}{c}366 \\
(\mathbf{1 0 0 \% )}\end{array}$ \\
\hline English & $161(55.1 \%)$ & $16(5.5 \%)$ & $53(18.2 \%)$ & $62(21.2 \%)$ & $\begin{array}{c}\mathbf{2 9 2} \\
(\mathbf{1 0 0 \% )}\end{array}$ \\
\hline Others & $3(27.3 \%)$ & $1(9.1 \%)$ & $2(18.2 \%)$ & $5(45.5 \%)$ & $\mathbf{1 1 ( \mathbf { 1 0 0 \% ) }}$ \\
\hline Total & $\mathbf{3 6 7 ( 5 4 . 9 \% )}$ & $\mathbf{7 2 ( \mathbf { 1 0 . 8 \% ) }}$ & $\mathbf{1 0 0 ( \mathbf { 1 4 . 9 \% ) }}$ & $\mathbf{1 3 0 ( \mathbf { 1 9 . 4 \% ) }}$ & $\begin{array}{c}\mathbf{6 6 9} \\
\mathbf{( 1 0 0 \% )}\end{array}$ \\
\hline
\end{tabular}

Table 1.2 Previous occupation of soldier by nationality $-2 / 28^{\text {th }}$ (North Gloucestershire) Regiment

Note 1: Skilled trades includes Wheelwright, Taylor, Sawyer, Sliversmith, Painter, Baker, Butcher, Clerk.

Note 2: Others include Miner, Servant, Tanner, Hocklar.

Note 3: Twenty four individuals have no trade or nationality recorded and are excluded from this analysis.

Source: Description book 2/28 ${ }^{\text {th }}$ (North Gloucestershire) Regiment $1812-1817$, (TNA WO 25/361).

The motivations for enlistment and the socio-economic backgrounds of soldiers provide a common reference point for the integration and assimilation of the various national groupings. The previous occupation of men enlisting was predominately Labourer (54.9 per cent). This figure when analysed by nationality, was similar for both Irish (55.5 per cent) and English (55.1 per cent). The next significant occupation at 10.8 per cent is Weaver with Irish (15 per cent) and English (5.5 per cent). Coss in his analysis of a sample from 17 regiments serving in the Peninsula has broadly similar findings with 40.5 per cent of recruits being Labourers and 18.03 per cent Weavers. ${ }^{42}$ Although army pay was low by comparison with other occupations, it did provide steady employment during periods of economic hardship and this coupled with a sizeable bounty paid upon enlistment featured high when considering enlistment. ${ }^{43}$

Pockett found a distinct Irish character among Irish soldiers which resulted in a 'stronger distinction between the Irish and the English'. ${ }^{44}$ This he states resulted from the fact that Ireland was not as politically integrated within the United Kingdom as Scotland or Wales despite the recent Act of Union (1801). In this regard we can surmise that Irish soldiers identified themselves as a separate nationality and indeed this sense of difference is 
evident in the accounts of both Irish and English officers of the period. However, Leerssen observes that the development of nationalism in Ireland 'took place by and large over the heads of the native peasantry, whose main concern was livelihood rather than nationhood' with its development mainly occurring within the middle classes. ${ }^{45}$

While the majority of Irish appear likely to have enlisted for economic reasons this was not always the reason. Sergeant Major Adams of the $95^{\text {th }}$ Rifles, who originally transferred from the Donegal militia, had been a croppy or rebel in 1798 and had fought at Vinegar Hill. To escape capture, he hid in the wilds of Connemara before joining the militia. Adams was eventually commissioned following his participation in the Forlorn Hope at San Sebastien (1813) but died in America while serving with his new regiment. ${ }^{46}$

Overall the same socio-economic factors appear to be motivating men regardless of nationality to enlist. These similar motivations for enlistment assists our understanding of the underlying factors which facilitated the integration of the Irish soldier into English and Scottish regiments and specifically into his primary group discussed in part three.

\begin{tabular}{|cc|ccc|c|}
\hline Nationality & $\mathbf{1 5}$ and under & $\mathbf{1 6 - 2 1}$ & $\mathbf{2 2} \mathbf{- 3 5}$ & Over $\mathbf{3 5}$ & Totals \\
\hline Irish & 31 & 197 & 131 & 6 & $\mathbf{3 6 5}$ \\
\hline English & $14^{1}$ & 127 & 140 & 9 & $\mathbf{2 9 0}$ \\
\hline Scottish & 0 & 4 & 3 & 1 & $\mathbf{8}$ \\
\hline Others & 0 & $4^{2}$ & $9^{3}$ & 0 & $\mathbf{1 3}$ \\
\hline Total & $\mathbf{4 5 ( 6 \% )}$ & $\mathbf{3 3 2 ( 4 9 \% )}$ & $\mathbf{2 8 3 ( 4 2 \% )}$ & $\mathbf{1 6 ( 2 \% )}$ & $\begin{array}{c}\mathbf{6 7 6} \\
\mathbf{( 1 0 0 \% )}\end{array}$ \\
\hline
\end{tabular}

Table 1.3 Age on enlistment by nationality $-2 / 28^{\text {th }}$ (North Gloucestershire) Regiment

Note 1: One English boy was enlisted from the Royal Asylum

Note 2: Nationality is unknown except for one 20 year old American - Lewis from New York who enlisted in Dublin in 1806.

Note 3: Nationality is unknown except for two Germans.

Note 4: Seventeen soldiers have no age entered on enlistment or the writing is illegible.

Source: Description book 2/28 ${ }^{\text {th }}$ (North Gloucestershire) Regiment $1812-1817$, (TNA WO 25/361).

The mean age for Irish soldiers was 21.4 years, slightly younger than English soldiers at 22.7 years and Scottish soldiers who were the oldest at 24 years. Coss, using a larger survey population of over 7,000 British soldiers, found Irish soldiers were slightly older than their English comrades across the British army with a mean age of 22.9 years. ${ }^{47}$ Irish boys aged 15 and under are disproportionately represented at 68 per cent within the regiment compared to English boys at 32 per cent. The youngest recruit into the regiment was nine year old Jason Campbell from Co. Fermanagh who enlisted in Plymouth in 1803. Described as 4 feet 9 inches in height with a fair complexion, young Jason appeared to have followed an elder relative from his home parish into the regiment, possibly his brother named Jonathan Campbell who enlisted as a seventeen year old in 1797. Young 
boys enlisted for various reasons, some following their father or older relative into the regiment. Most were initially assigned as drummer boys but this did not always protect them in combat as Irishman Edward Costello recounts:

A little fellow, a drummer boy, belonging to the $88^{\text {th }}$

(Connaught Rangers) regiment, was lying wounded and crying bitterly, his leg being broken by a shot. On telling him I would get him carried by the Frenchman if he wished, "Oh no! - oh no!" said the boy; "I don't care for myself. Look at my poor father, where he lies!" pointing to a man shot through the head, lying weltering in a gore of blood. Poor little fellow! I gave him a couple of dollars, and called some men to his assistance, when I was compelled to leave him. ${ }^{48}$

The Irish soldier has been portrayed in certain contemporary accounts of the period and subsequent historical works as drunken, ill-disciplined and only effective when competently led by English officers. Oman, states that the majority of men brought for court martial were Irish with regiments suffering disciplinary problems due to "having more than their share of wild Irish or scum of the town'49. The figures upon which he bases his assessment were collected from court martial records where the accused had an Irish sounding name. Out of 280 court martials he estimates that 80 were Irish based on their names alone and 'probably a good many more'. Oman's assessment is flawed for two reasons; firstly he has no empirical evidence as to the soldiers' nationality other than the sound of their name. Secondly, his resulting figures place the Irish at 28 per cent of the total number of accused - certainly not a significant statistical variance when considered that 30 - 40 per cent of Wellington's army were Irish. ${ }^{50}$

A number of contemporary memoirs and accounts from the Peninsula also portray a negative image of the discipline of the Irish soldier. Lieutenant Peter Le Mesurier of the 'Fighting' $9^{\text {th }}$ (East Norfolk) Regiment wrote home in 1812 that 'a number of those fellows are Irishmen, which accounts for their Conduct, for I really do believe that if the whole of the Irishmen in the Regt: were picked out and sent about their business we should have a very decent set of Men in the Regt'.$^{51}$ Not all memoirs recollect ill-discipline and drunkenness as a trait unique to Irish soldiers. One Irish soldier's account describes the prevailing attitude to drinking among his comrades on his first night in barracks which contained three hundred men - 'They were chiefly volunteers, and of course young soldiers. Many were Irish, many more were English, several Welshmen were intermingled, and a few Scotchmen came in to complete the whole. Most of these, and that was the only point of general resemblance, had indulged in excessive drinking... Never will the occurrence of that night be effaced from my mind' ${ }^{52}$ In his memoir he narrates various incidents related to excessive drinking, however, he does not specifically mentioned the Irish being more prone than any other soldiers. For him excessive drinking was the only common trait among the various nationalities he encountered in the army. The Irish officer Grattan, who could also be accused of bias given his nationality, observed that 'the English soldier is to the full as drunken as the Irish and not half so pleasant in his liquor'. In the same breath he acknowledged that some of the best regiments in Wellington's army were English such as the $43^{\text {rd }}$ (Monmouthshire) and $45^{\text {th }}$ (Nottinghamshire) regiments, demonstrating an element of objectivity in his accounts. ${ }^{53}$ 
Although more research is warranted on this subject it is worth considering why such views may have taken hold. One reason may be related to the most fundamental aspect of the Irish contribution - their sheer numbers. Although Wellington's army was by no definition 'English' consisting of many foreign contingents the prevalence of Irish soldiers ensured they stood out as a distinct group, attracting any negative stereotypical inferences. However, these negative behaviours were also prevalent in the other British regional groupings as many memoirs and accounts attest. A further factor to be considered is many of the subsequent memoirs and accounts detailing the negative aspects of the Irish character were published during the Victorian period when periodicals such as Punch regularly depicted the Irish as drunken, bawdy and untrustworthy ${ }^{54}$. Indeed, some studies suggest that while such excesses of behaviour were attributable to all British soldiers of the period, Irish soldiers were used as a readily acceptable scapegoat especially against the backdrop of Catholic Emancipation and agrarian unrest in Ireland following the Napoleonic wars. ${ }^{55}$

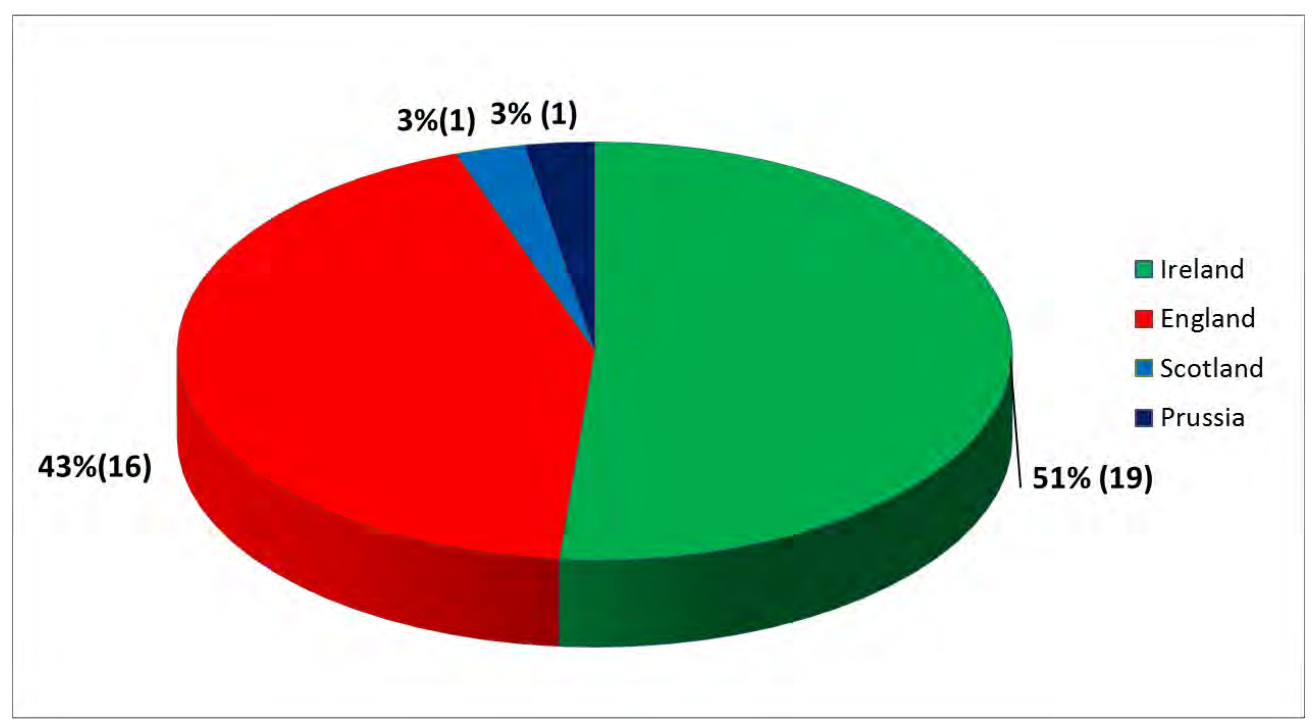

\section{Chart 1.3 Desertion rates by nationality- $2 / 28^{\text {th }}$ (North Gloucestershire) Regiment}

Source: Description book 2/28 ${ }^{\text {th }}$ (North Gloucestershire) Regiment $1812-1817$, (TNA WO 25/361).

Desertion was the most serious discipline issue and an endemic problem for the British army throughout the period. The problem was more acute for regiments on home service and particularly when stationed in Ireland. Divall found that both battalions of the $30^{\text {th }}$ Regiment had the highest number of desertions when stationed in Ireland during 1803 04. This figure dropped dramatically when the battalions were sent to India and to the Peninsula ${ }^{56}$. A common held view, evident not only in the contemporary accounts of the period but also in official opinions, was that the Irish were more prone than other soldiers to desertion. In reply to question in the House of Commons as to why no Irish soldiers were permitted to enlist in the $10^{\text {th }}$ Hussars Colonel Palmer replied 'because Irishmen desert'. ${ }^{57}$

Analysis of the desertion rates for the $2 / 28^{\text {th }}$ (North Gloucestershire) does not show a significant variation in the desertion rate for Irish soldiers - 51 per cent of deserters were 
Irish while 43 per cent were English. These percentages are broadly proportionate to the national composition of the battalion. However, this may be somewhat misleading as Divall's findings based on other primary sources would support the view that Irish soldiers were more prone to desertion particularly when stationed in Ireland. These may be related to the attractive bounty available upon each enlistment supposing the recruit was not recognised as a deserter and the ease of desertion within one's own country. Desertion while on active duty in Portugal and Spain was much less frequent given the difficulty for deserters among a foreign population.

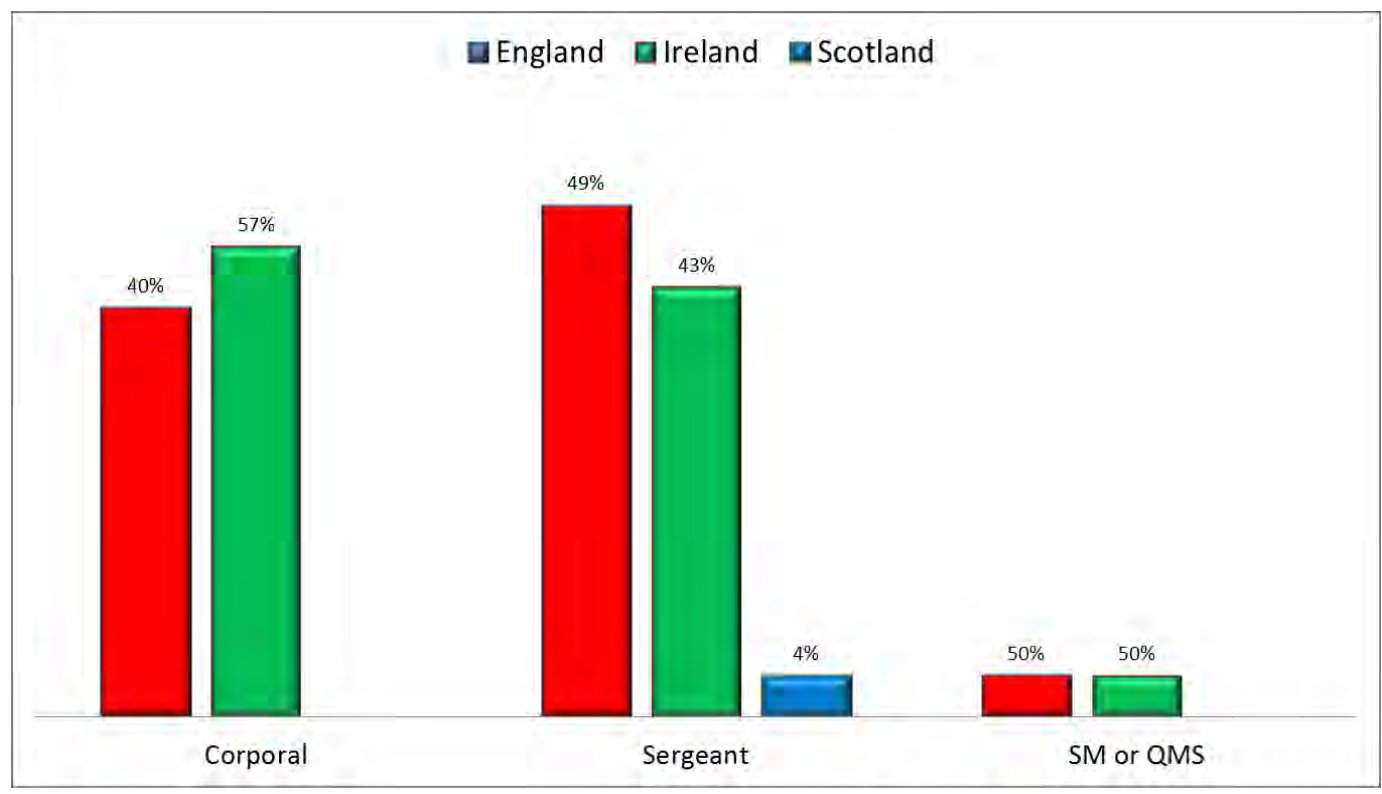

\section{Chart 1.4 Promotion rates by nationality $-2 / 28^{\text {th }}$ (North Gloucestershire) Regiment}

Source: Description book 2/28 ${ }^{\text {th }}$ (North Gloucestershire) Regiment $1812-1817$, (TNA WO 25/361).

Critical to the effectiveness of the regiment, in and out of combat, was the role of the non-commissioned officers (NCOs). The most senior NCO within the regiment was the sergeant major (SM) and it was not unusual for these men to find themselves promoted into the officer ranks as happened to SM Adams above ${ }^{58}$. James describes the SM as follows:

The sergeant-major is the first non-commissioned officer in the regiment after the quartermaster. He is, in fact, an assistant to the adjutant. It is his peculiar duty to be perfect master of everything that relates to drill: and it is always expected, that he should set an example, to the rest of the non-commissioned officers, of manly, soldier-like, and zealous activity. He must be thoroughly acquainted with all the details which regard the interior management and the discipline of the regiment. For this purpose he must be a good penman, and must keep regular lists of the sergeants and corporals. ${ }^{59}$ 
Men attained the rank of SM and QMS on merit and ability. Within the $2 / 28^{\text {th }}$ (North Gloucestershire) Regiment two Irish soldiers Bourke and Irvine, who interestingly appear to be from the same parish (Ballymere) in Co. Armagh, held the rank of SM or QMS ${ }^{60}$. Both were described as 'weavers' upon enlistment indicating they had little or no formal education. In the intervening years both must have applied themselves diligently to their duties rising up through the ranks and attaining the necessary numerate and literacy skills required for the highest NCO rank within the British army. Many British regiments established regimental schools for the purposes of educating soldiers. These were usually organised at the behest of the more enlightened regimental commanding officers. One such school established in 1807 by Lt Col Barclay of the $52^{\text {nd }}$ (Oxfordshire) Light Infantry was funded by a subscription of those who enrolled based on their rank. ${ }^{61}$

Bourke was 18 years of age when he joined the regiment in 1784 waiting 16 years before becoming SM/QMS. Irvine had a more rapid career progression. Enlisting in 1807 he was a Sergeant by 1809 and SM/QMS by May 1814, his rapid promotion possibly reflecting the demands for experienced and skilled soldiers during wartime. The career paths of both these men were not reflective of the stereotypical drunken, ill-disciplined Irish soldier portrayed in certain contemporary accounts and subsequent histories. Nor would it be reflective of institutional discrimination on behalf of an 'English' regiment.

Sergeants and, to a lesser degree, corporals, acted as the vital link between the officers of the regiment and the enlisted men. It was they who ensured that the orders and intentions of the officers were carried out efficiently and effectively by the enlisted men.

As experienced soldiers they acted as a vital source of guidance and support for the more junior officer particularly the ensigns. One Irish soldier in the $43^{\text {rd }}$ (Monmouthshire) Regiment who was promoted to corporal in May 1809 records that 'The regularity of my conduct, as a private soldier, attracted the notice of the officers, and I had the satisfaction of hearing that there was some probability of an elevation from the place I held in the ranks to that of corporal in the British army, - a distinction to which my wishes were earnestly directed' ${ }^{62}$ The percentage comparisons for Irish men at the ranks of Sergeant (43 per cent) and Corporal (57 per cent) within the $2 / 28^{\text {th }}$ (North

Gloucestershire) Regiment are comparable with their English comrades with slightly more Irish corporals and English sergeants.

In May 1813, the British army introduced an additional honorary rank of Colour Sergeant. The memorandum from Horse Guards describes the particulars required for the appointment of Colour Sergeant and included 'to hold out to the most deserving of them a station somewhat raised over their comrades...it shall be the province of these sergeants exclusively to be orderly over the colours when in the field...' ${ }^{63}$. Each battalion was authorised to appoint ten colour sergeants on the authority of the battalion commander. Within the $30^{\text {th }}$ (Cambridgeshire) Regiment the regimental commanding officer required that nominations for the rank must be 'zealous', 'gallant', 'honest', and 'trustworthy'. Of the original ten colour sergeants appointed within this regiment, five were Irish soldiers. It is also of note that all but one of the ten appointees was a labourer. William Brien (or Bryan) was a labourer from Cashel, Tipperary who enlisted in 1795 while Matthew Donnellan also a labourer was from Roscommon. Donnellan's promotion was rapid within the regiment serving only one year as a private and two and half as a corporal. Both had seen extensive active service with the second battalion in the 
Peninsular campaign. Donnellan had also been the battalion clerk during his service completing official returns with 'exemplary neatness' ${ }^{64}$ From original humble beginnings both men had evidently taken every opportunity afforded them to advance within the British army.

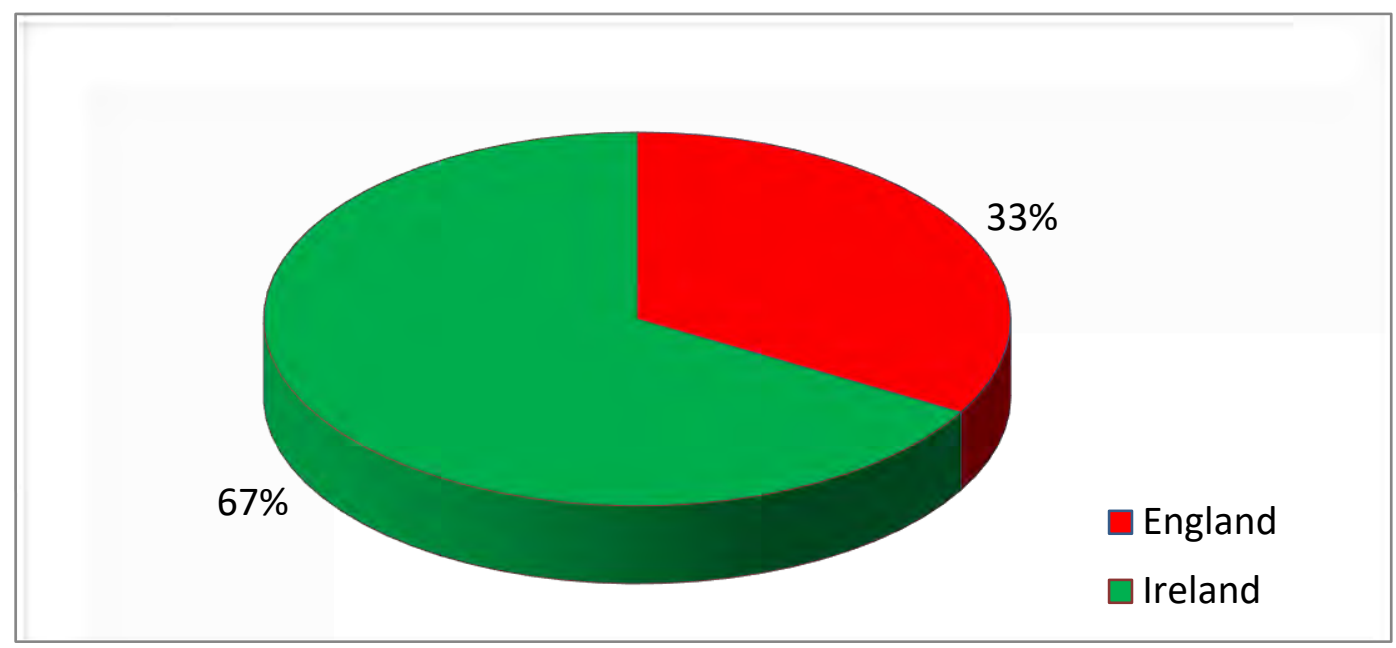

\section{Chart 1.5 Demotion rates by nationality- $2 / 28^{\text {th }}$ (North Gloucestershire) Regiment}

Source: Description book 2/28 ${ }^{\text {th }}$ (North Gloucestershire) Regiment $1812-1817$, (TNA WO 25/361).

Irishmen appear to have been twice as likely to be demoted in rank as their British counterparts - demotion reflecting a less serious form of punishment than that for desertion, and usually related to drunkenness or other minor offences. Divall finds that regimental courts martial records for the $30^{\text {th }}$ (Cambridgeshire) Regiment of Foot show a ratio of 3:4 for English to Irish offenders ${ }^{65}$. This, she argues, suggests that the Irish were more likely to offend but not to the extent which justifies Oman's earlier remarks. ${ }^{66}$

With a significant number of Catholic soldiers serving within its ranks it is important to consider the army's attitude to religion and its impact on their integration within the army. At the regimental level O'Neill, a devout Roman Catholic, recounts how he received 300 lashes for refusing to attend an Anglican church parade while serving with the $28^{\text {th }}$ (North Gloucestershire) Regiment on Gibraltar. ${ }^{67}$ However, O'Neill's memoirs of his military life must be treated with a degree of wariness as they lack certain specifics and are best described as generic remembrances. O'Neill's reliability is further questioned as he freely admits to deserting and re-enlisting on four separate occasions to receive a bounty. ${ }^{68}$ Other accounts by Irish soldiers serving in English regiments are notable for their lack of reference to any interference by the military authorities to religious observance. However, while Ellis notes in his research regarding promotion within the $28^{\text {th }}$ (North Gloucestershire) Regiment that there may have been a bias towards the promotion of Irish Protestants over Catholics he cannot definitively conclude as the religious background of each soldier is unknown. ${ }^{69}$

At more senior levels within the military establishment, Sir Edward Littlehales, Under Secretary, Military Department, Dublin, in a letter to Wellesley-Pole addressed a matter regarding the interference in the religious duties of Patrick Spence, a Catholic soldier 
serving with the Dublin County Militia. ${ }^{70}$ That the Under-Secretary saw fit to correspond with the Chief Secretary concerning one Catholic soldier demonstrates the serious of such incidences to the military establishment. Despite specific instances of religious intolerance, it is accepted by some historians that British soldiers whether Protestant or Catholic, were generally indifferent to their religion preferring the company of reliable and trustworthy comrades. ${ }^{71}$

Most existing accounts portray the Irish contribution mainly through the lens of Wellington's Irish regiments. ${ }^{72}$ However, it is clear that Irish soldiers were serving in greater numbers in English and Scottish infantry regiments. As Pockett concludes although there was a pervasive British identity amongst the British soldiers, 'it was not always the dominant one, and many of the soldiers also developed their own regional identities which were for some, as powerful as their feelings of 'Britishness' ${ }^{73}$ This finding of identity at an individual level is important when coupled with Divall's definition of an Anglo-Irish regiment. Using her conclusion a number of Wellington's English and Scottish infantry regiments were Anglo / Scots -Irish in their national composition and it must be assumed, in their identity and character. In effect, by more accurately defining the national character of Wellington's Peninsula regiments we can begin to understand and appreciate the wider contribution of the Irish soldier.

The experiences of these Irish soldiers at the regimental level is an important starting point in understanding how their numerical contribution was transformed into combat effectiveness as discussed in part three. Subsequent historical research has accepted the negative Irish stereotype of hard drinking and ill-disciplined in the absence of any detailed analysis or even close scrutiny. Yet Irish soldiers were considered to be of a quality and possessed the competencies required to hold junior command positions within English regiments such as the $2 / 28^{\text {th }}$ (North Gloucestershire). Demotion rates found for the $2 / 28^{\text {th }}$ (North Gloucestershire) Regiment and discipline statistics for the $30^{\text {th }}$

(Cambridgeshire) Regiment further establish that Irish soldiers were not committing offences to any more significantly greater extent than their English or Scottish comrades. Given that the selected regiments were seasoned combat units who relied on the calibre of their NCOs and enlisted men lends further credence to the need for a more detailed reassessment of these views. These ill formed and negative perceptions have contributed to an under appreciation of the Irish contribution and deserve closer examination using evidence-based assessments.

\section{PART TWO. THE IRISH OFFICER}

\section{Irish Protestant Ascendancy and the British army}

If the Irish NCO and enlisted man are understudied figures, the Irish officer is even more so. However, before examining the extent of the Irish officer's contribution consideration must be given to his cultural identity within the British army and to what extent he viewed himself as being Irish or English. While mainland Britain was divided along class lines with limited religious tensions Ireland's divisions were different. While Catholics formed the majority of the population, the ruling class were almost exclusively drawn from the Protestant Ascendancy of the Church of Ireland. 
The question of Ascendancy identity has long been a focus of debate for scholars. Foster describes the Ascendancy as viewing themselves as 'Irishmen with English civil rights' while Bartlett challenges this idea and whether they viewed Ireland in quite so positive terms determining not to be seen as simply a colony of Britain. ${ }^{74}$ McDonnell concludes that the Ascendancy may have had a dual identity - one where they looked to England as a model for ruling Ireland yet cognisant and keen to demonstrate their own abilities. ${ }^{75}$ Both these views are evident in the accounts and memoirs left to us by serving Irish officers with many referring to themselves as Irishmen. Captain Ross-Lewin's diary offers a unique insight into the Irish officer serving in the Peninsula campaigns. Throughout his account Ross-Lewin considers himself and fellow officers born in Ireland as Irishmen and distinct from English or Scottish officers. Indeed, he uses the term 'Irishmen' to differentiate himself and fellow Irish officers and views Ireland as his 'native country'. ${ }^{76}$

Following the cessation of the Williamite wars in the 1690s many Protestant officers in William's army were granted lands and settled in Ireland. Being a minority ruling class among the more numerous Irish Catholics fostered strong martial traditions of service in the early to mid-eighteenth century characterised by the 'Protestant defence tradition'. During this period the Protestant Ascendancy also relied on support from the English government and crown in maintaining their ruling position. Although aspiring to certain English characteristics they also sought a degree of separation for Ireland and tensions existed at the political level between Dublin and Westminster. Bartlett identifies the beginnings of Protestant Patriotism which distinguished the outlook, views and indeed self-identity of the Irish Ascendancy from 1690s onwards. He characterises it as a refusal on the part of Irish Protestants to accept Ireland as a colony of the British Empire but rather a co-equal partner with a 'sister or brother kingdom' relationship. ${ }^{77}$ The Patriot political movement in the 1770s is viewed by some historians as an early form of Protestant nationalism. ${ }^{78}$ This view of themselves was facilitated by the decline in the indigenous Catholic power base following the Williamite wars and accelerated throughout the eighteenth century as the spectre of a Jacobite rebellion dissipated and reliance on the English establishment for support waned. This Protestant defence tradition or relying on one's own community to safeguard their property and position of power was easily transferred to service in the regular British army by the time of the Revolutionary and Napoleonic wars.

A number of Ascendancy families whose descendants served in the Peninsular army rose to prominence during this period. The Honourable William Ponsonby, who served as a cavalry brigade commander under Wellington, was descended from a Cromwellian soldier. ${ }^{79}$ Other less prominent Ascendancy families also had strong traditions of military service. Captain Harry Ross-Lewin mentioned above was also descended from an old Cromwellian officer ${ }^{80}$. Ross-Lewin and others could not be described as British officer in a one-dimensional English sense. His sense of being Irish (he also spoke Gaelic) permeates his accounts but he was also very much a product of his time and strongly adhered to an ethos of service to 'king and country'. His Peninsular war accounts support the view espoused by Pockett and McDonnell that there is no one identifiable Irish identity within the British army of the period. 


\section{Profile of the Irish officer in the British army}

The onset of the Revolutionary and Napoleonic wars and increasing demands on manpower resources meant that the traditional social classes could not supply the required numbers of officers to the British army. Recent analysis of the social composition of the officer class indicates that increasingly during the period they came from what would later be referred to as the middle classes. ${ }^{81}$ Many Irish officers within the line regiments were sons of vicars. Purefoy Lockwood, Percy Neville and Richard Mayne, were such Irish officers who served in the $30^{\text {th }}$ (Cambridgeshire) Regiment. ${ }^{82}$ Captain Robert Robinson, another vicar' son from Armagh, served with the $1^{\text {st }}$ (Royal Scots) Regiment in the Peninsular. His middle class social standing did not prevent him from aspiring to the socially elite Foot Guards when he wrote home in February 1809, following the retreat to Corunna 'Our men, I am glad to say, are in tolerable good health and with the exception of the Guards, the freshest by far of those who have returned from Spain. I have been exerting myself a good deal to make it known my object is at present to exchange into the Guards which though uncertain will, I am told, may in time be accomplished'. ${ }^{83}$ Other sons of vicars served in more senior appointments such as Sir Andrew Francis Barnard from Fahan, Co. Donegal, who commanded the elite $1 / 95^{\text {th }}$ Rifles and served as a brigade commander in the Light Division during the Vitoria campaign $(1813)^{.84}$

Others were the products of the emerging business and professional classes such as David La Touche of an Irish banking family who served with the $30^{\text {th }}$ (Cambridgeshire) Regiment. ${ }^{85}$ Although the La Touche family were known for their charitable works in Dublin it did not prevent fellow officers describing the young La Touche as being 'truly despicable' ${ }^{86}$ Captain John Dobbs was a son of a Dublin barrister whose family were again descendants of an English officer who had settled in Ireland and married into an ancient Gaelic family, the O'Neill clan and the Earls of Tyrone. Dobb's brothers also served in the army: Joseph with the $52^{\text {nd }}$ (Oxfordshire) Light Infantry, William with the Armagh militia and Francis with the $12^{\text {th }}$ (East Suffolk) Regiment. John Dobbs himself served in the $52^{\text {nd }}$ (Oxfordshire) Light Infantry Regiment throughout all the major engagements of the regiment from Sabugal (1811) to battles of Nive and Bayonne (1814). Following the war he became the Governor of the county asylum in Waterford. ${ }^{87}$

Although officially precluded from joining the regular army due to the requirements of the Test Acts, incidences exist of Irish Catholic officers serving with Wellington's army. ${ }^{88}$ Ensign William Sullivan served in the $30^{\text {th }}$ Cambridgeshire Regiment from $1803 .{ }^{89}$ Sullivan's religion only came to official attention in 1827 when he was still serving with the regiment. ${ }^{90}$ Another Irish Catholic officer Major Peter O'Hare had a remarkable career in the elite $95^{\text {th }}$ Rifles. Originally serving in the $69^{\text {th }}$ Foot as a surgeon's mate, O'Hare transferred to the Experimental Rifle Corps in 1800, the forerunners of the $95^{\text {th }}$ Rifles. Serving in the Peninsula as a major he was appointed acting battalion commander by the end of 1811. O'Hare eventually met his end in the breach of Badajoz in April 1812, his naked torso showing the holes from numerous musket balls. O'Hare career is remarkable in the context of his rise from humble beginnings as a surgeon's mate. It was only through serving his time and hard campaigning that he was to reach such heights within the $95^{\text {th }}$ Rifles. In many regards he epitomised the hard-fighting Irish soldier who took every advantage the British army offered. ${ }^{91}$ 
It is interesting to consider contemporary discussions and views of the period as to why the preclusion of Catholics from holding the king's commission was not universally applied. Charles James wrote in 1800

Every nobleman, or man of independent property, be his rank what it may, who professes himself a Papist, or is known to adhere to the Church of Rome, and consequently is forbidden to take the oath of supremacy, as enjoined in the Mutiny Act, is at the mercy of every informer, and may be fined five hundred pounds. As the bugbear of Jacobitism is justly lost, or shortly must be so, in the extinction of the Stewart line, this disheartening stigma upon a very large proportion of His Majesty's most loyal subject, ought to be removed. It is a galling circumstance to every Roman Catholic gentleman, that whilst he is eagerly stepping forward, with a considerable stake of his own, to co-operate in the general defence of his property, he should only be permitted to shed his blood and risk his fortune by sufferance or connivance. ${ }^{92}$

It was not until 1829 that the army could officially commission Catholic officers. James's views suggest that more enlightened practices prevailed with regard to Catholic officers especially when the realities of the war with France and the consequent manpower demands arose. It is probable that more Irish Catholic officers served during the Peninsular war and O'Sullivan and O'Hare were not isolated cases and is certainly an area worthy of further research.

\section{Case Study 2 - The campaigns of 1813 and the Irish officer}

In 1813 Wellington's Army entered Spain for the third and final time resulting in the withdrawal of the French armies across the Pyrenees and into France by 1814 . This crucial period was a turning point in the campaign, and saw Wellington's army reach its pinnacle as it proved its combat effectiveness. The war and the wider strategic considerations for the British government had created a huge demand for men of ability and ambition to command her forces. An estimated 35 per cent of the British army officer corps were Irish born based on regimental inspection returns for 1813 with English 39 per cent and Scottish 24 per cent. ${ }^{93}$ The Irish officer was to play a key role in delivering the decisive battlefield victories of 1813 - 1814.

The use of the divisional structure was innovative for the British army of the period and one which Wellington was to alter and change over the seven years of campaigning. This autonomous structure allowed Wellington's commanders to operate independently for extended periods over large areas of operations. ${ }^{94}$ By 1813 he had in place an effective organisational structure that was not only suited for administrative and logistical purposes but was an effective combat instrument. Wellington also incorporated Portuguese brigades into his divisions which increased their strength while also avoiding some of the problems associated with the co-ordination of independent allied formations. The autonomous nature of these units demanded commanders who could use their initiative to ensure their actions conformed to overall British strategy. The latent problems of effectively integrating Portuguese units further required an understanding of diplomacy and the recognition of cultural differences. Wellington ensured in so far as 
possible only the best of the available senior officers would be placed in such important command positions despite any political manoeuvrings from London. Not all were to prove successful in their role but by 1813 the combat effectiveness of his army based on competent divisional commanders ensured the eventual defeat of French forces in the Peninsula.

Thirty-three per cent of Wellington's nine infantry divisional commanders at the beginning of 1813 were Irish, a higher percentage than their English equivalents at 22 per cent (see appendix 3 ). Wellington considered the 'Light, $3^{\text {rd }}$ and $4^{\text {th }}$ Divisions are the best within the army and of these the Light division is the best' ${ }^{95}$ Both the Third and Fourth divisions were commanded by Irish officers - Pakenham and Lowry Cole. The Honourable Edward Pakenham (1778 - 1815) born in Co. Westmeath and brother in law to Wellington went on to command the British army in North America during the war of 1812 and died following wounds received at the Battle of New Orleans (1814). Sir Galbraith Lowry Cole (1772 - 1842) born in Dublin was to likewise rise to prominence during the Peninsular campaign and was subsequently appointed Governor of Mauritius and Governor of the Cape Colony after the war.

Other lesser known Irish divisional commanders included Major General John Hamilton (1755 - 1835) from Co. Tyrone who was to command the Portuguese Division. Since 1809 , fellow Irish officer William Carr Beresford (1768 - 1854) had been successfully reorganising the Portuguese army. By 1811 there were ten Portuguese brigades - six assigned to British infantry divisions, two operated independently and two formed the Portuguese Division. Hamilton, initially commissioned as an ensign with the East India Company in 1773, transferred to the British army in 1788. He was to command the Portuguese throughout most of the Peninsula campaign and was finally promoted to Lieutenant General in May 1814. The division undertook their first major action at the battle of Albuera (1811) where Hamilton's performance was favourably commented upon in the London Gazette which stated he 'evinced the utmost steadiness and courage' ${ }^{96}$

Unlike Wellington's infantry, the cavalry was not tactically employed at the divisional level rather operating as brigades. This meant that cavalry brigade commanders made key operational decisions. Wellington's cavalry brigade commanders on 1 January 1813 included a number of Irish officers such as the well-known Honourable William Ponsonby of Waterloo fame and the lessor known General John Ormsby Vandeleur.

Vandeleur (1763 - 1849) was born in Co. Clare and came from a large Irish family with a long tradition of military service. ${ }^{97}$ Vandeleur saw previous service in the West Indies (1788), Flanders (1795) and the Second Anglo-Maratha War (1803 -05) assuming command of his regiment $8^{\text {th }}$ Light Dragoons when its commander and his cousin Major General Thomas Pakenham Vandeleur was killed. No cavalry command was available upon his arrival in the Peninsula and he was posted to the Light Division leading his brigade in the assault on Ciudad Rodrigo in 1812. He assumed command of the division when 'Black Bob' Craufurd was mortally wounded in the assault - he was later wounded fighting alongside the $52^{\text {nd }}$ (Oxfordshire) Light Infantry Regiment. He went on to serve with his brigade at Salamanca (1812) and Vitoria (1813). In July 1813 his repeated requests to Wellington for a cavalry command were granted and he was given command of a Light Dragoon brigade. Vandeleur was to serve under Wellington again during the 
Waterloo campaign (1815), when as senior surviving cavalry commander he led the British cavalry into Paris. It was his timely decision to support his fellow Irish officer Ponsonby when the charge by the Union brigade ran into trouble that ultimately saved this formation from complete destruction. Although a competent commander, Wellington did not have a high opinion of Vandeluer possibly resulting from his repeated requests for a cavalry appointment during the Peninsula campaign. He was to die in Dublin in 1844 and is buried at Mount Jerome cemetery. Well thought of by his peers and subordinates his brigade major Captain Harry Smith called him 'a fine, gentleman-like old Irish hero'. ${ }^{98}$

Equally as important to the efficient and effective operation of the army especially on the battlefield were Wellington's brigade commanders. The calibre and competency of these men varied as with all other officers and Wellington sought to have those who were unfit to command removed. The majority were competent commanders and a number were to go on to successful careers within and outside the army, however many were to meet their end in the Peninsula where an estimated 63 per cent died from sickness, accidents and disease. ${ }^{99}$

Major General Robert Ross (1766 - 1814) born in Rostrevor, Co. Down, attended Trinity College, Dublin before being commissioned into the $25^{\text {th }}$ (Kings Own Borderers) Regiment in 1789 . By 1803 he had assumed command of the regiment's $1^{\text {st }}$ battalion and was present at the battle of Maida (1806) against the French, where he was mentioned in dispatches 'The most brilliant parts on this stage were acted by Colonels Kempt and Ross; to them the glory of the fight at Maida is chiefly due'. ${ }^{100}$ In 1812 Ross commanding the $20^{\text {th }}$ (East Devonshire) Regiment joined Wellington in the Peninsula where it later saw action at the battle of Vitoria (1813). Shortly after the battle in July he was appointed brigade commander in the Fourth Division. At the battle of Orthes (1814) Ross was shot in the face while leading his brigade which suffered heavy casualties as it tried to dislodge French troops from their positions in the village of St Boes and the surrounding hills. After the war Ross was sent to North America during the War of 1812, where he led British forces in the capture of Washington D.C. He was killed outside North Point, Maryland having ridden to the front of his brigade when skirmishing with American riflemen had broken out. Wellington was to write in a letter to Horse Guards upon Ross's promotion 'I look upon Skerrett, Ross, and Power to be three of the best officers in the service' ${ }^{101}$

Major General Denis Pack (1772 -1823), born in Kilkenny, was the son of the Dean of Ossory, another scion of a religious family. Pack was appointed brigade commander in the Sixth Division in July 1813, shortly after the battle of Vitoria. Pack's early career was to see him serve in Flanders in 1794 before assuming command of the $71^{\text {st }}$ (Highland) Regiment in 1806. He was to see action throughout the Peninsular campaign at Rolica, Vimiero, Ciudad Rodrigo, the pivotal battle of Vitoria finally fighting his way through the Pyrenees to Toulouse in 1814. He was to serve under Wellington again as a brigade commander at Waterloo in Picton's Fifth Division. Following the Napoleonic wars Pack was to become Lieutenant-Governor of Plymouth and upon his death in 1823 was entombed in St. Canice's Cathedral in Kilkenny.

Major General Lord Aylmer (1775 - 1850) was one of the few members of the Irish peerage to serve in the Peninsula. As such he was also one of the few Irish officers to 
serve in the socially elite First Division or Gentlemen's' Sons, as a brigade commander. His subsequent career as a colonial administrator - Governor General of British North America in 1830, ended with his recall in 1835 amid political unrest in Canada and suggestions that his handling of the situation had exacerbated it. ${ }^{102}$

The regiment was the basic tactical unit upon which the brigades and divisions were built and for the men who served in them it was their home. The regimental officers had the closest contact with the enlisted soldier whether he was Irish, English or Scottish and had a direct impact on his assimilation into his regiment and resulting combat effectiveness. The sense of identity and belonging to the regimental 'family' and the role of the Irish officer should not be underestimated as a contributor to effectiveness of English and Scottish regiments. 'Captain Dyas could not boast of high birth or fortune, but he had a lion's heart. Ireland never produced a better soldier, nor one more qualified to fill a high station in the army, being in possession of that secret how to govern those under him not through fear but love' so recounted English private William Wheeler of the $51^{\text {st }}\left(2^{\text {nd }}\right.$ Yorkshire West Riding) Light Infantry Regiment ${ }^{103}$. On many occasions during the Peninsular war the actions of individual regiments were to prove critical to the wider engagement. During one particular fragmented engagement for the Light Brigade along the Coa river in July 1810 an Irish soldier recounted how '...[a] few moments later and we should have been surrounded...but, here in every other part of the field, the quickness and knowledge of the battalion officer remedied the faults of the General' ${ }^{104}$

An accurate calculation of the numerical contribution of Irish officers to English and Scottish regiments is more difficult to determine than for Irish NCOs and enlisted men. The place of birth for officers was not captured in the regimental description books of the period and unlike the more senior Irish brigade and divisional commanders many of their lives remained obscure. Except for those who left us their memoirs and accounts with references to fellow regimental officers of Irish birth we can determine an estimate of their numbers. Within the elite $52^{\text {nd }}$ (Oxfordshire) Light Infantry Regiment based on the Army List for 1813 we can identify four Irish officers out of a total of seventeen whose nationality can be determined (see appendix 6). The regiment across both its battalions had an establishment of eighty-five officers. What is of note was that Irish officers appear across the various commissioned ranks from major to lieutenant, indicating that they were attaining promotion and not clustered at the more junior regimental ranks. Based on these findings we can extrapolate that approximately 25 per cent of officers at the regimental rank were Irish and this figure was probably higher if a full sample could be determined. By 1813 the officers of the $52^{\text {nd }}$ (Oxfordshire) Light Infantry had accumulated five years combat experience since arriving in the Peninsula in 1808. Some of the more senior Irish regimental officers such as Major Charles Rowan (1782 -1852) had been junior lieutenants at Shorncliffe in 1803 learning their trade under the watchful eye of Sir John Moore. ${ }^{105}$ By 1813 the demands of combat would have forged them into seasoned campaigners. ${ }^{106}$ It would be to officers such as Rowan that newly commissioned ensigns and lieutenants would look to as role models. Rowan would bring his military leadership and experience to bear in his subsequent career as the founding Commissioner for the Metropolitan Police in 1829. ${ }^{107}$

In summary, the Irish officer serving in the Peninsula came predominately from the ruling Protestant Ascendancy class with a small number of Catholic officers. He probably viewed 
himself as Irish but also a loyal subject of the king and he would have believed in the British Empire and his role in maintaining and increasing its power on the global stage. Arising from this he would have sought to benefit from this position becoming the principal source for experienced administrators among the senior ranks of the expanding British Empire. ${ }^{108}$. He would probably not have seen Ireland as a subject colony of that Empire but rather an equal participant. To ensure this status he would likely have believed in a degree of self-determination for Ireland but within the broader political union of the United Kingdom. His military contribution to the Peninsular army was evident at all levels of command - divisional commanders 33 per cent, brigade commanders 23 per cent and at the regimental level using the $52^{\text {nd }}$ (Oxfordshire) Light Infantry as a sample 25 per cent.

\section{PART THREE. COMBAT EFFECTIVENESS OF THE IRISH SOLDIER}

In examining the contribution of the Irish soldier to the Peninsular army that contribution must be placed and understood in the context of the combat effectiveness of Wellington's army. Combat effectiveness encapsulates attributes at both the organisational and the individual levels within a military force and is ultimately measured by an army's ability to defeat the enemy. But how was Wellington able to defeat the French on the battlefield? To answer this question and how the Irish soldier contributed to that ability an examination of the tactical system employed by Wellington is required.

\section{British tactical system and the Irish soldier}

The British army in the Peninsula was not a well-balanced all-arms force similar to that employed by Napoleon. ${ }^{109}$ Wellington was not able to rely on his artillery or cavalry to the extent of his French adversaries and was required to develop a different tactical system to compensate for these deficiencies. ${ }^{110}$ The resulting system was to see the British infantryman become Wellington's dominant tactical tool of which the Irish comprised approx. 34 per cent. ${ }^{111}$

Wellington's tactical system consisted initially of a heavy skirmish line of light infantry forward of his main battle line, which was in a reverse slope defensive position. These specialised soldiers performed a key role in defeating the French system of attack and a large number of their ranks were filled by Irish soldiers as discussed later.

Oman maintained that the superior firepower of the British infantry alone was the key factor in Wellington's system. By deploying in two ranks, as opposed to the more conventional three, British infantry were able to bring increased firepower to bear on advancing French columns of attack ${ }^{112}$. A number of subsequent historians have challenged this view. Griffith and Hughes contend that the limitations of the flintlock musket coupled with the poor visibility of a black powder battlefield negated the effectiveness of a massed volley. ${ }^{113}$ Nosworthy further identifies discrepancies between Oman's view and the first-hand accounts which consistently describe the British delivering a single short-range volley before levelling bayonets and delivering 'a devilmay-care charge'. ${ }^{114}$ Physical firepower alone could not explain the defeat of the French columns. 
Recent research into the tactics of the Revolutionary and Napoleonic wars has identified the importance of the psychological dimension of battlefield. ${ }^{115}$ Coss and Haythornthwaite contend that a close-range volley in combination with the use of the bayonet charge resulted in a psychological defeat of the French ${ }^{116}$. Although the use of the bayonet did not inflict significant casualties, its psychological impact proved destructive on an already demoralised enemy following the impact of both the heavy skirmish line and close-range volley of the main battle line. ${ }^{117}$ British bayonet charges were also a distinctive feature of the British tactical system in the offensive role such as at Salamanca (1812) and Vitoria (1813) and the majority of Wellington's battles involved at least one bayonet charge. ${ }^{118}$ The effects of such a tactical system were best described by the French military writer Marquis de Chambray who wrote:

...the French infantry... charges the infantry of the enemy with shouldered arms. The manoeuvre is executed ...has often succeeded against the Austrians and other troops, who begin firing at too great a distance, but it has always failed against the English, who only open their fire within a short distance. It can easily be imagined that a body, which charges another, and which itself is charged, after having received a fire which has carried destruction and disorder into its ranks, must necessarily be overthrown. ${ }^{119}$

Other contemporary accounts describe the ferociousness of bayonet charges delivered by Wellington's shock troops - his Irish regiments. ${ }^{120}$ Bartlett and Jeffery discuss the Irish martial character of the ancient Gaelic tradition so much valued by foreign armies from the time of the Wild Geese. ${ }^{121}$ Indeed, English soldiers also recognised this natural fighting ability in their Irish comrades 'he fought like a devil and would not surrender as long as he was able to lift his arm' ${ }^{122}$ Coming from a mainly rural population the Irish soldier was also a physically hardy individual predisposed to the rigours of military campaigning and fighting. Grattan observed that 'without shoes and rations' the Irish soldiers in the $88^{\text {th }}$ (Connaught Rangers) Regiment 'were in their element... as they (regular food and shoes) had been in all probability been outside their acquaintance'. ${ }^{123}$ Returning to the $2 / 28^{\text {th }}$ when place of birth is further analysed, 78 per cent of Irish recruits were from rural backgrounds; a preferred type of soldier for the recruiting sergeants given their hardiness, as attested to by Grattan. As the majority of the Irish rank and file in both Irish and English regiments were from the native Irish peasantry their presence would have contributed to the successful execution of Wellington's tactical system. This natural ability for a soldier's life and a war like character was viewed positively by seasoned regimental commanders.

\section{Combat motivation and behaviour of the Irish soldier}

There has been little consideration of the underlying factors that motivated Irish soldiers to fight so effectively within English and Scottish regiments. Certainly, their sheer numbers in certain regiments created a distinct Irish identity and character, as already discussed. However, this does not explain all the factors facilitating their contribution. Recent studies of factors motivating soldiers in modern conflicts can be applied to our understanding of the combat effectiveness of Irish soldiers during the Peninsula campaign. 
Coss among others has cogently argued that primary group cohesion was the main contributor to behaviour in combat and resulting combat effectiveness. ${ }^{124}$ The primary group within Wellington's Peninsular army was a soldier's six - eight fellow messmates. ${ }^{125}$ This small grouping, multiplied across company, battalion and regimental levels was the basic building block for cohesiveness within Wellington's army. The need to conform to the group's social norms, values and expectations would have superseded other previous loyalties, acting as a substitute family. Indeed Irishman Edward Costello serving in the $95^{\text {th }}$ Rifles when considering familial ties mused 'I have no such ties, save my comrades'. ${ }^{126}$

Stouffer et al identified primary group cohesion as serving two functions; firstly it set and enforced group standards and behaviours while also supporting and sustaining the individual to combat stresses he would not normally have been able to cope with. ${ }^{127}$ Incidents of acting to one's own advantage to the detriment of the group would have attracted varying degrees of censure from verbal rebuke to ostracism. 'Long Tom' of Lincoln of the $95^{\text {th }}$ Rifles was one such unfortunate who when noticed missing during an action near the Redinha in 1811 was shunned upon returning to his messmates that evening. Desperate to regain his place within the group he crossed to the French lines, killing a French soldier and returning with the body to prove his courage. ${ }^{128}$

It was the primary group that allowed for the integration of the various nationalities within each regiment. Primary group cohesion would have been particularly important for regiments with a significant percentage of one nationality over another. Whatever a soldier's previous economic, national or religious background if he conformed to the group's values he would become part of a close band. Costello provides us with a glimpse of the relationship that existed between the various nationalities after a day's action involving his own messmates:

Blood an ounds' said Dan Kelly, bouncing up from his reclining position: 'don't drink all the wine boys, until we hear something about our absent messmates'. 'Does any of you know where Jack Connor is?' He was shot through the body when we took the first gun...Where is Will John?' asked Bob Roberts, 'The ball passed through his head' 'Musha boys! Is there any hope of poor Jemmy Copely'...said Tom Tracey, earnestly... 'Poor Copely!' replied another 'both his legs were knocked off by a round shot'. 'Tracey lay his head on his kit and was silent. 'Why by Jasus! exclaimed Tracey they have kilt half our mess, Poor Jemmy Copley! Poor Jemmy the best comrade I ever had. ${ }^{129}$

The significance of this scene was the presence of Irish and English voices and regardless of origin the sentiments for lost messmates are heartfelt and genuine. Indeed, such bonds were carried through to civilian life. Harris of the $95^{\text {th }}$ Rifles, the shepherd's son from Dorsetshire, attributed his survival during the retreat to Corunna to his close companion James Brooks from Ireland ' a strapping resolute fellow...I often think of him with feelings of gratitude as I sit at my work in Richmond Street, Soho'. ${ }^{130}$

The more human side of the Irish character particularly his humour would have further assisted in his assimilation among his messmates. Holmes noted this characteristic of the 
Irish among numerous accounts and memoirs from the period. ${ }^{131}$ Harris again recounts on the contribution of three Irish brothers during the retreat to Corunna '...even in that dreadful business, their light-heartedness and attempts at fun served to keep up the spirits of many men who would else have been broken-hearted' ${ }^{132}$ The Irish sense of humour, particularly in the face of adversity, shines through in these reminisces. DunneLynch finds that this irrepressible good humour had a number of important functions - a means of self-protection, to ease tensions and stresses, to raise morale and as a means of defiance, all important components for the maintenance of combat effectiveness. ${ }^{133}$

The organisation in which the British soldier enlisted viewed him as coming from the lowest levels of society. While on campaign he was to suffer from the deprivations inflicted on him by the enemy, rudimentary medical care and an inefficient commissariat. In short, his messmates were his only recourse for the physical and emotional support needed to deal with the situation in which he found himself. As Coss states 'marginalized to an extreme extent' the strength of the bonds between these men was the lifeline needed to survive. ${ }^{134}$

Shils and Morris in their research into cohesion and disintegration in the Wehrmacht during World War II found that desertions and surrenders were more prevalent among heterogeneous Wehrmacht units comprised of Austrians, Poles and Czechs randomly mixed across the parent unit. ${ }^{135}$ The underlying reason was a weakened primary group cohesion caused by linguistic communication difficulties between the soldiers themselves and equally important between soldiers and their non-commissioned officers (NCOs) and officers. In such groups the language difficulties resulted in resentment over perceived prejudices and weakened leadership due to an inability to identify with their officers. This finding is relevant in further understanding how Irish soldiers could effectively contribute to Wellington's army. Despite coming from a different country, the Irish soldier spoke a common language as his English or Scottish comrades. In addition, the prevalence of Irish officers and NCOs within Wellington's army as discussed earlier, further simplified this assimilation.

Stouffer et al found that prayer as well as a fear of letting down one's comrades was a factor in maintaining soldiers in combat. ${ }^{136}$ Ben-Shalom and Benbenisty found that although religion was a significant factor for Israeli soldiers coping with the stresses of combat, faith-based coping mechanisms were only really resorted to in the heat of battle and were not a more long term mechanism for dealing with the daily rigours of life in a combat zone. ${ }^{137}$ When considering Irish soldiers we find them predominantly Catholic in a Protestant military organisation and although religion may have been an important factor in their lives the absence of Catholic priests would not have negatively affected their assimilation into Wellington's army.

The need to conform to the expectations of the group also ensured cohesion at higher levels of the organisation i.e. the regiment. However, here also lay a weakness - if sufficient pressure to the point of breaking, was exerted at the primary group level this could quickly transfer across the regiment leading to a breakdown in unit cohesion. An important line exists between the discipline imposed by the military authorities and the values and mores of the primary group within every regiment. If the imposition of discipline was to such an extreme extent or was perceived as unjustified it could result in 
a conflict between the values of the primary group and the higher organisational levels, with negative results on the combat performance of the unit concerned. Coss identifies this need to ensure unity between the subgroups and the army itself otherwise behaviours that are in conflict with the military leadership's intentions will surface and potentially lead to disintegration. ${ }^{138}$ However, the likelihood of this occurring was not as high as would be initially expected. While we may perceive the discipline imposed on the British, including Irish soldier as inhumane it was not dissimilar to the sentences imposed by the British criminal courts of the period. ${ }^{139} \mathrm{It}$ is also important to remember that despite the views of subsequent historians Irish soldiers were no more significantly prone to ill-disciple than their English or Scottish comrades as discussed in chapter two.

\section{Case study 3 -The Irish soldier and the combat effectiveness of the Light Division}

No other formation within Wellington's army, outside of the Irish regiments appreciated or understood the combat effectiveness of the Irish soldier more than the famed Light Division. The onset of the Revolutionary wars was to see a resurgence of light infantry on European battlefields as the French used them as an integral part of their system of arms. ${ }^{140}$ From 1800 the British army began to convert existing line infantry regiments to the developing light infantry role. The progressive increase in the tactical skill and deployment of this arm was a new innovation for the British army and one which Wellington would employ to its fullest as part of his tactical system during his Peninsula campaigns.

Early on in the development of the light infantry the British army began to recognise that Irish and Scottish soldiers had natural attributes which made them particularly suited to the role of light infantry mainly due to the predominance of a rural population in both countries. ${ }^{141}$ Colonel William Stewart, a leading practitioner and advocate for the use of light infantry, wrote to Sir Henry Dundas Secretary of State for War proposing that the British army should recruit Irish and Scottish men to form the new indigenous light infantry units. ${ }^{142}$ Other influential figures also recognised the contribution that Irish soldiers could make to these new units. The French émigré General Charles Francois Dumouriez wrote in 1803 'One should raise more men for this service in Ireland and in Scotland than from England, not only because they are tougher, do not tire as easily and are more sturdy, but also because Irish noblemen, above all, having more power over their peasants, enlist them with more ease and less expense' ${ }^{143}$ Chappell also notes that in its efforts to address the shortage of light infantry soldiers the British army turned to hiring mercenaries from German states, émigré royalist French soldiers and Catholics from Ireland. ${ }^{144}$ While Ireland was seen as a recruiting ground for line infantry regiments, elite regiments were identifying other qualities of the Irish soldier that made them especially suited for more specialised military duties.

The $52^{\text {nd }}$ (Oxfordshire) Regiment of Foot was one such regiment. Its first battalion was formally designated a light infantry regiment in January 1803 while the second battalion was re-designated the $96^{\text {th }}$ Regiment of Foot. ${ }^{145}$ The regiment quickly transferred those deemed unsuitable for light infantry duties to the new $96^{\text {th }}$ Regiment, replacing vacancies with suitable men from the second battalion. The newly designated $52^{\text {nd }}$ (Oxfordshire) Light Infantry Regiment reported to Major General Sir John Moore at Shorncliffe Camp to commence training as a light infantry regiment where it was joined by other units. ${ }^{146}$ The 
training and development of the $52^{\text {nd }}$ Regiment as a light infantry unit became the template for the conversion of other line regiments and around it and the $95^{\text {th }}$ Rifles would develop the nucleus of what would become the famed Light Division. ${ }^{147}$

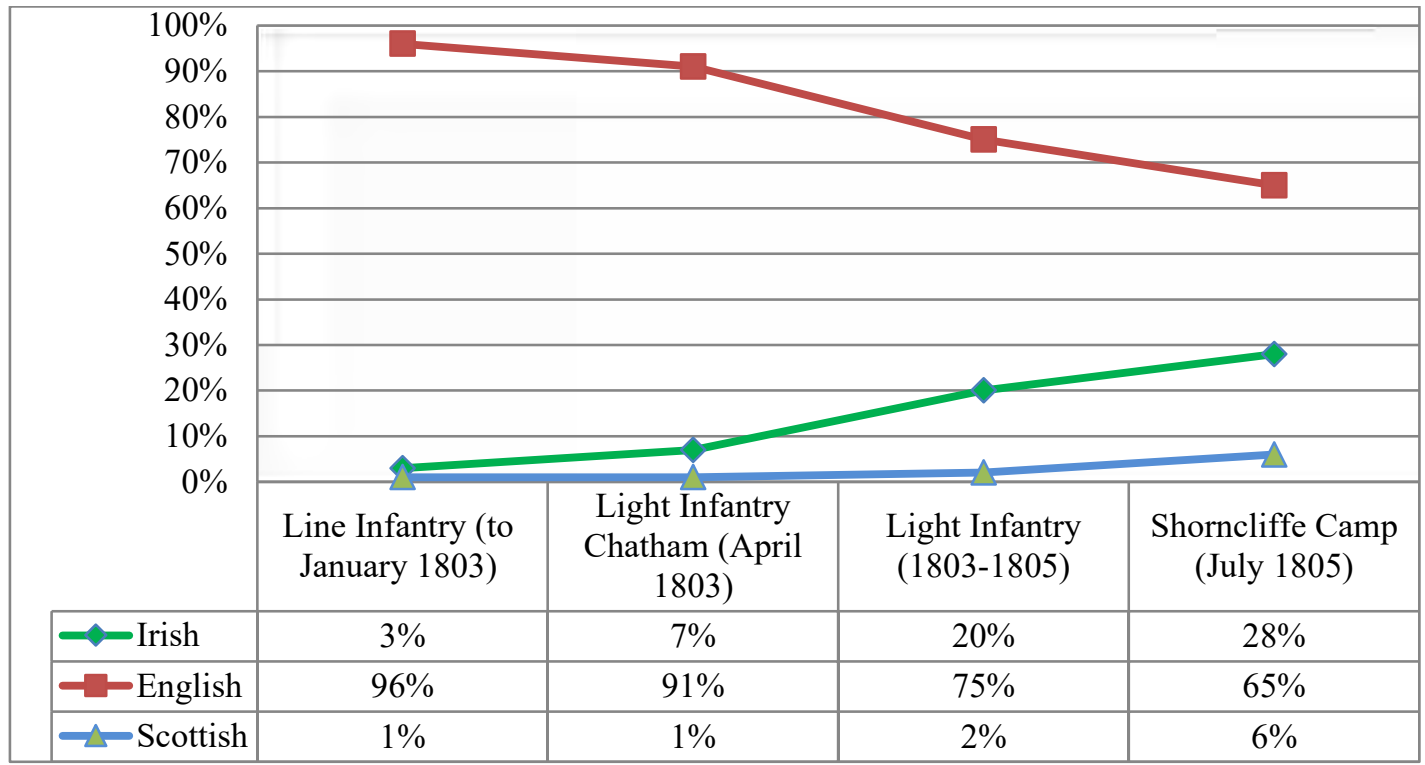

Chart 3.1: Recruitment trends of the $52^{\text {nd }}$ (Oxfordshire) Regiment $1803-1805$

Source: Description book, $1 / 52^{\text {nd }}$ Regiment of Foot 1790 s to 1803 , Description book $52^{\text {nd }}$ Regiment Light Infantry $1803-1808$, (TNA, WO25/405 and WO 25/406).

Although most historical research has focused on the development of light infantry tactics and training at Shorncliffe other important changes were also experienced by these units. An analysis of the regimental description books covering the period of transition from line to light infantry regiment shows that the percentage of Irish (and Scottish) soldiers increased dramatically within a short period of time - from 3 per cent in January 1803 to 28 per cent in July 1805 . This change could be attributed to the wider increase in recruitment of Irish soldiers into the British army over the same period. However, this factor alone does not explain such a significant increase in a little over 2.5 years, especially as the regiment was not garrisoned in Ireland. ${ }^{148}$ The only nationality to decrease over the period in large numbers was English soldiers.

One factor may assist in explaining this increase -a recruitment policy focusing on Irish soldiers. The cross culling between the two battalions of the $52^{\text {nd }}$ (Oxfordshire) Regiment of Foot prior to reporting to Shorncliffe demonstrates that the new light infantry regiment was selective in its choice of soldier. Further analysis of the description books reveal that prior to conversion to a light infantry regiment the $52^{\text {nd }}$ Regiment of Foot was undertaking little, if any recruitment in Ireland. Moorsom informs us that in 1804 the new light infantry regiment dispatched a number of officers on recruitment duties, however he does not tell us where. ${ }^{149}$ Again the description books provide an answer - the regiment began to actively recruit in Ireland with officers such as Major Wade and Captain George Napier and Irishmen Major Charles Rowan and Captain Joseph Dobbs enlisting large numbers of Irishmen in Limerick, Dublin, Cork, Belfast and elsewhere. ${ }^{150}$ This was opposite to the circumstances pertaining to recruitment for the $2 / 28^{\text {th }}$ (North 
Gloucestershire) Regiment's where the majority of Irish enlistments occurred when the battalion was stationed in Ireland.

These findings coupled with the contemporary views expressed on the suitability of Irish men indicate that a recruiting policy targeting Irish men for service in the light infantry was in practice within the $52^{\text {nd }}$ (Oxfordshire) Regiment and most probably among the other light infantry and rifle regiments garrisoned at Shorncliffe. A further factor to support this position is that Colonel William Stewart, who held positive views on the suitability of Irish men for light infantry duties, was the commanding officer of the newly designated $95^{\text {th }}$ Rifles while brigaded under Sir John Moore with the 52nd Regiment at Shorncliffe. ${ }^{151}$ It can be surmised that his views were known among the officers given the atmosphere of innovative thinking, general discussion and formal lecturing officers received on light infantry training and ethos that prevailed at Shorncliffe during the period.

The training of a light infantryman demanded soldiers of a higher calibre than those normally found within the British army. 'Vigilance, activity, and intelligence, are particularly requisite... The chief intelligence required in a light infantry man is that he should know how to take advantage of every circumstance...to fire seldom and always with effect should be their chief study' ... so instructed one contemporary manual of instruction. ${ }^{152}$ From the outset it was decided that the light infantry regiments would be able to perform regular line infantry and light infantry roles hence close order drill and linear battlefield tactics also formed part of their training. The light infantry recruit was further trained to be an adept marksman. Although equipped with a shorter barrel light infantry musket as opposed to the Baker rifle all light infantry regiments received increased training in marksmanship and spent considerably more time in live firing than their line infantry colleagues. In effect their dual role and specialised training allowed these regiments to act as a force multiplier for senior commanders. The physical nature of their role would demand a hardier and physically more robust soldier than generally encountered in the line regiments, particularly with regard to marching long distances, an important feature of campaigning in the Peninsula. The Light Division was especially famed for its ability to cover long distances at speed and the physical abilities of the Irish soldier in this regard would have been recognised. Irish soldiers were already identified as being more accustomed to the rigours of campaigning coming from a more rural based population than English soldiers.

One of the most famous stories concerning an enlisted man from the Peninsula campaign relates to Tomas Plunket (or Plunkett), a labourer from Wexford, who served in the $95^{\text {th }}$ Rifles. During the retreat to Corunna in January 1809 the $95^{\text {th }}$ Rifles while acting as rear guard for Moore's retreating army were attacked by French cavalry. During the ensuing engagement Plunket achieved the remarkable feat of shooting French cavalry general Auguste Colbert from a range well in excess of 200 yards. This was followed by a second equally remarkable shot which felled Colbert's trumpet major. The death of their commanding officer threw the French cavalry attack into disarray demonstrating the impact of one highly skilled (Irish) soldier on the battlefield. ${ }^{153}$ 


\begin{tabular}{|l|c|c|c|c|c|}
\hline \multicolumn{1}{|c}{ Rank } & Private & Corporal & \multicolumn{1}{c}{ Sergeant } & \multicolumn{1}{c|}{ SM / QMS } & Total \\
\hline $\begin{array}{l}\text { Regimental } \\
\text { Total }\end{array}$ & 984 & 49 & 45 & 4 & 1082 \\
\hline Irish Total & 182 & 14 & 11 & 1 & 208 \\
\hline Percentage & $18 \%$ & $28 \%$ & $25 \%$ & $25 \%$ & $19 \%$ \\
\hline
\end{tabular}

Table 3.1: Irish soldiers by rank serving in the $2 / 52^{\text {nd }}$ (Oxfordshire) Regiment 1812 $-1814$

Source: Description book 2/52 ${ }^{\text {nd }}$ Regiment 1812 - 1814, (TNA WO 25/ 409).

Light infantry regiments also had a higher number of officers and NCOs than line regiments. The table above of the percentage of NCOs demonstrates the contribution to junior leadership by Irishmen within this elite regiment. Although the overall composition of Irish soldiers within the battalion was 19 per cent, Irish soldiers are attaining a proportionally higher number of junior leadership positions ranging from 25 per cent to 28 per cent, indicating their better experience and suitability.

While the men of the $52^{\text {nd }}$ Regiment and the Light Division in general were to excel as skirmishers one particular battle demonstrates the combat effectiveness of these units in simultaneously performing line infantry and skirmishing roles - the battle of Fuentes de Onoro fought from 3 - 5 May 1811.

\begin{tabular}{|c|c|c|c|c|}
\hline Regiment & $\begin{array}{c}1 / 43^{\text {rd }} \\
\text { (Monmouthshire) } \\
\text { Regiment }\end{array}$ & $\begin{array}{c}2 / 43^{\text {rd }} \\
\text { (Monmouthshire) } \\
\text { Regiment }\end{array}$ & $\begin{array}{c}2 / 52^{\text {nd }} \\
\text { (Oxfordshire) }^{\text {Regiment }}\end{array}$ & 2/95 ${ }^{\text {th }}$ Rifles \\
\hline $\begin{array}{l}\text { Year of } \\
\text { Inspecti } \\
\text { on }\end{array}$ & 1808 & 1811 & 1810 & 1808 \\
\hline Irish & $40 \%$ & $28 \%$ & $34 \%$ & $35 \%$ \\
\hline
\end{tabular}

Table 3.2: Irish soldiers serving in the Light Division $1811^{154}$

Source: K. B. Linch 'The recruitment of the British army $1807-1815^{\prime}$ (PhD thesis University of Leeds, 2001), pp 278-81 and Steve Brown, 'Bound for Mondego Bay: British infantry regimental movements to and from the Peninsula $1808-1814$ ', http://www.napoleon-series.org/military/battles and campaigns (28 March, 2018).

Note 1: Details for the $1^{\text {st }}$ and $3^{\text {rd }}$ battalions of the $95^{\text {th }}$ Rifles were unavailable.

By April 1811 Wellington had driven the French under Marshal Massena from Portugal with the exception of a small toehold in the border fortress town of Almeida. Wellington was resolved to capturing Almeida in advance of his invasion of Spain and by the end of April had invested the town in preparation for an assault. However, his forces were thinly spread covering other avenues of approach along the border and in May Massena attempted to relieve the besieged town. Wellington moved his available forces to counter the relief attempt and both armies converged near the village of Fuentes de 
Onoro. Wellington's 37,500 troops faced Massena's force of 48,500 and following a day of inconclusive fighting on 4 May Wellington extended his defensive line further south anticipating a French attempt to outflank his position. ${ }^{155}$

On 5 May the French attacked the newly extended right wing of Wellington's army. The newly formed Seventh Division quickly found itself in a perilous position with French cavalry attempting to isolate it from the main British army. Wellington ordered the Light Division under General 'Black Bob' Craufurd south to support the threatened division and so began what Weller described as the finest hour in Craufurd's career. ${ }^{156}$ Craufurd and the 4,000 men of the Light Division quickly relived the Seventh Division which withdrew northwards with the light infantrymen covering their retreat. French cavalry forced Craufurd's regiments to form square but these unwieldy formations would prove tempting targets for French artillery and advancing columns of infantry. By keeping the three battalions of the $52^{\text {nd }}$ (Oxfordshire) and $43^{\text {rd }}$ (Monmouthshire) regiments in square formation to repel the repeated cavalry charges and using the $95^{\text {th }}$ riflemen in small company sized groups to skirmish and engage the enemy artillery with long range accurate rifle fire, the Light Division commenced a fighting withdrawal. The sharpshooters from the $95^{\text {th }}$ Rifles consisted of men such as 'Flynn... a good specimen of the hardfighting Irish who inspired endless comment among the $95^{\text {th }}$ officers' ${ }^{157}$ Over the next number of hours the Light Division, with unnerving skill moved northwards to the main British line in alternate 'leaps and bounds'. Throughout the fighting withdrawal the formations kept their nerve and discipline. Effectively isolated into individual battalions they moved in a co-ordinated fashion displaying a level of competency at divisional level manoeuvres absent from many other British divisions. Finally reaching the British lines, the division suffered less than seventy casualties, a remarkably low rate for a unit engaged in sustained combat for several hours ${ }^{158}$. Oman was to call it 'a masterpiece of military evolution'. ${ }^{159}$

By checking and defeating the third and final French invasion of Portugal the way was open for the British army to move onto the offensive. Craufurd's tactical deployment of his units using a combination of line infantry tactics (square) and company sized skirmishing proved devastatingly effective, saving not only the Seventh Division but probably the entire British force. The outcome of Fuentes de Onoro would not have been achieved without the junior leadership skills within the regiments of the Light Division or the skill and proficiency of the individual light infantry man. That so many Irish soldiers were part of this formation at all levels demonstrates their contribution to the combat effectiveness of such elite units. It also validated decisions made by Moore and Stewart concerning the recruitment, training and promotion of such men.

While Wellington and his officers may not have understood the dynamics and interplay of group cohesion on combat effectiveness the more enlightened certainly recognised its results. They also recognised the contribution of Irish soldiers as demonstrated by the extent of their integration, both officers and enlisted men, into the Peninsular army. The functioning of primary group cohesion, although not really understood until the twentieth century, was certainly in operation within the Peninsular army. Irish soldiers were easily assimilated into English and Scottish regiments due to their martial characteristics, common language, similar social backgrounds and indeed the extent of Irish NCOs and officers already present in these regiments. In effect, the British army in 
the Peninsula was a microcosm of the society from which the Irish soldier had been recruited. This feeling of familiarity and inclusion would have facilitated the full contribution of the martial qualities for which the Irish soldier was renowned and which were important ingredients of Wellington's tactical system.

The contribution of the Irish soldier to the elite units of the Light Division demonstrates that there was further recognition of the value these men could bring over and above a purely numerically based contribution. Despite the somewhat superficial analysis of the Irish contribution by many subsequent historians, key officers of the period recognised the qualitative contribution that the Irish could bring to a new and innovative form of soldiering. Moore, Stewart and the views of other light infantry proponents concerning the system of discipline, training and esprit de corps developed at Shorncliffe had a lasting impact on the ethos of the wider British army post the Napoleonic wars. ${ }^{160}$ That the Irish soldier was identified as having the necessary talents for this system is evidence of the value-add their contribution was to Wellington and the outcome of the Peninsular war.

\section{CONCLUSION}

The aim of this paper was to assess the contribution of the Irish soldier to the British army's victory in the Peninsula. Although the main focus of previous assessments has been on Wellington's Irish regiments the majority of Irish soldiers served in English and Scottish units such as the $28^{\text {th }}$ (North Gloucestershire), $3 / 1^{\text {st }}$ (Royal Scots) and the elite $52^{\text {nd }}$ (Oxfordshire) regiments. The number of Irish soldiers in the British army should not be surprising as England had and would continue to rely on her empire for the provision of manpower and resources to safeguard and progress her interests. While a number of English and Scottish regiments, notably the Foot Guards and Highlanders sought to preserve a distinct national or clan identity this was not the situation with the majority of British army regiments and particularly those on service in the Peninsula. As has been discussed, many of Wellington's infantry regiments could be described as Anglo or Scots / Irish in their national composition. With estimates ranging from 30-40 per cent Wellington's army itself could be referred to also Anglo / Irish. Already this viewpoint is featuring in more recent research on the Peninsular army. ${ }^{161}$ As Pockett argues, and the findings of this paper support, regardless of national differences the Irish, Scottish and English soldier identified with their profession and had a distinct familial feeling within the regimental structure. ${ }^{162}$

A number of important features are evident when consideration of that contribution moves beyond a purely quantitative assessment. Not only were the Irish serving mainly in the infantry - the crucial component of Wellington's tactical system - but they were evident at all levels of command within regiments, brigades and divisions. They also assimilated into their new environment, the British army regimental system. Their hardy nature, good humour and above all their martial qualities were valued by their messmates forming close bonds which contributed to unit cohesion and combat effectiveness. The majority came from the same social-economic background, were of a similar age, spoke the same language and shared similar experiences as a social underclass as their English and Scottish comrades. Whatever differences did exist such as religion, the English, Irish and Scottish soldier had more in common to unite than to 
differentiate them. It was this ability of the British army and its regimental structure to harness and exploit the martial characteristics of the Irish soldier through effective integration and realisation of his combat effectiveness through a compatible tactical system that contributed to victory during the Peninsular war. ${ }^{163}$

It should be recognised that despite its perceived inequalities the early nineteenth century British army did offer advancement for men of exceptional talent regardless of nationality. Any assertion that Irish born soldiers were institutionally discriminated against within the army does not fully stand up to the evidence provided as part of this research. While incidents of discrimination certainly existed it would have been folly for the British army to instigate or even tacitly approve of such a policy across a significant proportion of its armed forces. English regiments promoted Irish soldiers based on merit and ability. Indeed, it is interesting to consider to what extent was the British army, as a fundamental pillar of the British establishment, at the forefront of Catholic Emancipation. Irish officers rose to senior command positions and many were to take their military training and experiences with them in building the British Empire after the Napoleonic wars. Despite their historical and religious differences the predominantly Catholic ranker and Protestant Ascendancy officer had one major and significant similarity - their martial heritage and shared history. While originating from separate traditions - native Irish on one hand and settler tradition on the other both found common cause and opportunity within the British army of the Revolutionary and Napoleonic war periods. In summary, the majority of the Irish contribution to the effectiveness of Wellington's Peninsular army originated outside of the Irish regiments and that contribution was critical to the overall victory in 1814.

But the Irish contribution during this crucial period of European history should also be considered through a wider lens. While the Irish contribution to the British army during the First World War has received much popular recognition and academic attention the same is not true for their contribution during the Napoleonic wars. Very few Irish families can or indeed have the inclination to trace a relative serving in the ranks of Wellington's army. However, the success of the Peninsular army and the Irish contribution to that success should be taken as the starting point for Irish involvement in the British army throughout the Victorian era, culminating in the First World War. While we tend to view that involvement through the reluctant eyes of a somewhat biased Ireland both sides were active participants one seeing an escape from economic hardship and opportunity for self-advancement the other realising the manpower resources needed to maintain and expand a growing global empire. It is fitting to conclude by reflecting on the words of one Irish Peninsula veteran and his views on the contribution of his fellow countrymen.

What foe could resist their united attack or penetrate the shield formed of the Rose, Shamrock and Thistle when closely bound together in a union strong and lasting? ${ }^{164}$ 
APPENDIX 1 ANGLO/SCOTS - IRISH INFANTRY REGIMENTS PENINSULAR ARMY

\begin{tabular}{|c|c|c|c|c|c|}
\hline & Regiment & Type & $\begin{array}{l}\text { Date of } \\
\text { census }\end{array}$ & $\begin{array}{c}\text { Irish } \\
\text { contribution }^{1}\end{array}$ & $\begin{array}{l}\text { Peninsula } \\
\text { service }^{2}\end{array}$ \\
\hline 1 & 3/1 ${ }^{\text {st }}$ (Royal Scots) & \multirow{8}{*}{ Line } & 1809 & $36 \%$ & $\begin{array}{c}\text { October } \\
1808\end{array}$ \\
\hline 2 & $1 / 7^{\text {th }}$ (Royal Fusiliers) & & 1810 & $39 \%$ & July 1810 \\
\hline 3 & $1 / 26^{\text {th }}$ (Cameronian) & & 1811 & $36 \%$ & 1811 \\
\hline 4 & $\begin{array}{c}1 / 28^{\text {th }} \text { (North } \\
\text { Gloucestershire) }\end{array}$ & & 1811 & $44 \%$ & July 1811 \\
\hline 5 & 29th (Worcestershire) & & 1811 & $34 \%$ & $1808-1811$ \\
\hline 6 & $\begin{array}{c}2 / 31^{\text {st }} \\
\text { (Huntingdonshire) }\end{array}$ & & 1807 & $32 \%$ & $\begin{array}{c}\text { November } \\
1808\end{array}$ \\
\hline 7 & 2/44 ${ }^{\text {th }}$ (East Essex) & & 1808 & $91 \%$ & April 1810 \\
\hline 8 & 2/66 ${ }^{\text {th }}$ (Berkshire) & & 1813 & $45 \%$ & $\begin{array}{c}\text { April } 1809 \text { - } \\
1814\end{array}$ \\
\hline 9 & $\begin{array}{c}1 / 43^{\text {rd }} \\
\text { (Monmouthshire) }\end{array}$ & \multirow{5}{*}{ Light } & 1807 & $42 \%$ & August 1808 \\
\hline 10 & $\begin{array}{c}2 / 43^{\text {rd }} \\
\text { (Monmouthshire) }\end{array}$ & & 1807 & $44 \%$ & $\begin{array}{c}\text { October } \\
1808\end{array}$ \\
\hline 11 & $52^{\text {nd }}$ (Oxfordshire) & & 1810 & $34 \%$ & March 1811 \\
\hline 12 & $68^{\text {th }}$ (Durham) & & 1811 & $42 \%$ & July 1811 \\
\hline 13 & $\begin{array}{l}71^{\text {st }} \text { (Glasgow } \\
\text { Highland) }\end{array}$ & & 1813 & $34 \%$ & $\begin{array}{c}1808-1811 \\
\text { and April } \\
1813\end{array}$ \\
\hline 14 & $2 / 95^{\text {th }}$ Rifles & Rifle & 1808 & $35 \%$ & August 1808 \\
\hline
\end{tabular}

Source K. B. Linch 'The recruitment of the British army $1807-1815$ ' (PhD thesis University of Leeds, 2001), pp $278-281$, Paterson. Robert, H. Pontius Pilate's bodyguard - a history of the First or the Royal Regiment of Foot. The Royal Scots (The Royal Regiment) volume one 1633 - 1918 (Edinburgh, 2001) and Steve Brown, 'Bound for Mondego Bay: British infantry regimental movements to and from the Peninsula 1808 - 1814', http://www.napoleon-series.org/military/battles and campaigns (28 March, 2018). 


\section{APPENDIX 2 DATABASE EXTRACT OF KEY DEMOGRAPHICAL AND SERVICE INFORMATION $2^{\text {ND }}$ BATTALION $28^{\text {TH }}$ (NORTH GLOUCESTERSHIRE) REGIMENT 1812 - 1817.}

An excel database was created containing the demographical details and service particulars pertaining to approx. 700 soldiers of the $2^{\text {nd }}$ battalion $28^{\text {th }}$ (North Gloucestershire) Regiment. The information was extracted from the regimental description book covering the period 1812 - 1817. Regimental description books provide a range of demographical and service information on each soldier within the regiment, including place of birth and enlistment, age, height, name of attesting officer, dates of enlistment, promotion and demotion and discharge particulars which other military service records do not provide. As a result, a more complete profile of the individual soldier and his service can be developed. The attached extract is for illustrative purposes and does not contain all service particulars included in the final excel database.

An analysis was conducted utilising the database to determine key patterns relating to the service of Irish born soldiers such as recruitment patterns, promotion trends and other key information relating to their service. This information was then cross analysed against English and Scottish soldiers serving in the same regiment to determine any statistical differences in the service between the various nationalities.

Similar research methodology was employed by Coss and Linch which although involving a larger number of regiments was restricted to a sample extract of individuals from the regimental description books

165. The methodology employed from the purposes of this thesis used a 100 per cent extract of all individuals contained in the description book. Certain information was not originally entered into the description book for a small number of individuals or the actual section of the book had deteriorated over the years. In such cases 'unknown' was entered in the database. The resulting findings were also compared with Coss and Linch's findings to identify any similarities and to determine any significant variances. 


\begin{tabular}{|c|c|c|c|c|c|c|}
\hline Surname & Rank & $\begin{array}{c}\text { Age on } \\
\text { Enlistment }\end{array}$ & $\begin{array}{l}\text { Country } \\
\text { of Birth }\end{array}$ & $\begin{array}{c}\text { Date of } \\
\text { Enlistment }\end{array}$ & $\begin{array}{c}\text { Country } \\
\text { of } \\
\text { Enlistment }\end{array}$ & Occupation \\
\hline Angel & Private & 19 & England & 1807 & England & Labourer \\
\hline Ashman & Private & 16 & England & 1804 & Ireland & Miner \\
\hline Archer & Corporal & 17 & England & 1794 & England & Labourer \\
\hline Anderson & Private & 19 & England & 1812 & England & Labourer \\
\hline Anderson & Private & 18 & England & 1812 & England & Labourer \\
\hline Anket & Private & 27 & England & 1806 & Ireland & Taylor \\
\hline Ansborough & Private & 25 & Ireland & 1805 & England & Unknown \\
\hline Atwood & Private & 20 & England & 1813 & England & Sweeper \\
\hline Andseur & Private & 18 & Ireland & 1813 & Ireland & Weaver \\
\hline Allwood & Private & 21 & Ireland & 1813 & Ireland & Unknown \\
\hline Bourke & SM / QMS & 18 & Ireland & 1784 & Ireland & Weaver \\
\hline Barrett & Private & 24 & Ireland & 1809 & Ireland & Labourer \\
\hline Bullock & Sergeant & 23 & England & 1793 & England & Minor \\
\hline Bailey & Private & 17 & Ireland & 1805 & Ireland & Labourer \\
\hline Bixes & Sergeant & 25 & Ireland & 1808 & Ireland & Weaver \\
\hline Bowden & Corporal & 24 & England & 1806 & Ireland & Labourer \\
\hline Bailey & Private & 15 & Ireland & 1806 & Ireland & Painter \\
\hline Blackmore & Private & 21 & England & 1806 & Ireland & Weaver \\
\hline Brown & Private & 27 & Ireland & 1810 & England & Labourer \\
\hline Bickle & Private & 21 & England & 1806 & Ireland & Unknown \\
\hline Booths & Private & 21 & Ireland & 1811 & Ireland & Book Binder \\
\hline Byrne & Private & 20 & Ireland & 1811 & England & Taylor \\
\hline Buggy & Private & 20 & Ireland & 1807 & Ireland & Butcher \\
\hline Brokinshire & Corporal & 25 & England & 1803 & Ireland & Labourer \\
\hline Brennan & Sergeant & 23 & Ireland & 1811 & Ireland & Labourer \\
\hline Brennan & Private & 22 & Ireland & 1809 & Ireland & Labourer \\
\hline Berry & Private & 26 & England & 1811 & England & Shoemaker \\
\hline Bell & Private & 22 & England & 1809 & England & Labourer \\
\hline Balkwell & Private & 29 & England & 1811 & England & Labourer \\
\hline Barns & Private & 25 & England & 1812 & England & Labourer \\
\hline Brody & Corporal & 19 & Ireland & 1811 & England & Cooper \\
\hline Bryan & Private & 20 & Ireland & 1811 & Ireland & Labourer \\
\hline Bowden & Private & 29 & England & 1812 & England & Minor \\
\hline Burne & Private & 15 & Ireland & 1806 & Ireland & Labourer \\
\hline Barkley & Private & 16 & Ireland & 1812 & Ireland & Weaver \\
\hline Brislan & Private & 27 & Ireland & 1812 & Ireland & Labourer \\
\hline Brooks & Private & 30 & England & 1812 & England & Labourer \\
\hline Braggwood & Private & 17 & England & 1812 & England & Labourer \\
\hline Banaghan & Private & 28 & Ireland & 1812 & England & Labourer \\
\hline
\end{tabular}


The Irish soldier in the British Army in the Peninsula Campaign

\begin{tabular}{|c|c|c|c|c|c|c|}
\hline Bligh & Private & 28 & Ireland & 1812 & England & Labourer \\
\hline Byrne & Private & 32 & Ireland & 1812 & Ireland & Labourer \\
\hline Burrows & Private & 18 & England & 1812 & England & Weaver \\
\hline Beere & Private & 20 & England & 1804 & Ireland & Labourer \\
\hline Barber & Private & 17 & England & 1812 & England & Labourer \\
\hline Bride & Private & 25 & England & 1812 & England & Labourer \\
\hline Boyle & Private & 20 & Ireland & 1812 & Ireland & Weaver \\
\hline Brown & Private & 21 & Ireland & 1812 & England & Potter \\
\hline Beer & Private & 33 & England & 1805 & Ireland & Weaver \\
\hline Buttins & Private & 30 & England & 1804 & Ireland & Labourer \\
\hline Beer & Private & 22 & England & 1812 & England & Labourer \\
\hline Barrow & Private & 18 & England & 1812 & England & Unknown \\
\hline Bush & Private & 17 & England & 1804 & Ireland & Unknown \\
\hline Bryon & Private & 21 & Ireland & 1812 & Ireland & Labourer \\
\hline Brids & Private & 40 & England & 1804 & Ireland & Labourer \\
\hline Burke & Private & 22 & Ireland & 1813 & Ireland & Labourer \\
\hline Brennan & Private & 19 & Ireland & 1813 & England & Labourer \\
\hline Bryon & Private & 18 & Ireland & 1812 & Ireland & Labourer \\
\hline Bradley & Private & 15 & Ireland & 1813 & Ireland & Labourer \\
\hline Bradley & Private & 26 & Ireland & 1813 & Ireland & Labourer \\
\hline Barry & Private & 16 & Ireland & 1813 & Ireland & Labourer \\
\hline Bagent & Private & 32 & England & 1803 & England & Labourer \\
\hline Brennan & Private & 15 & Ireland & 1807 & Ireland & Unknown \\
\hline Boyer & Private & 24 & Ireland & 1805 & Ireland & Unknown \\
\hline Browning & Private & 24 & Ireland & 1804 & Ireland & Labourer \\
\hline Browne & Private & 22 & Ireland & 1811 & Ireland & Labourer \\
\hline Bradshaw & Private & 21 & England & 1813 & England & Collier \\
\hline Bartlett & Private & 14 & Army & 1814 & England & Soldier \\
\hline Brown & Private & 34 & Ireland & 1806 & Ireland & Labourer \\
\hline Cundy & Private & 24 & England & 1806 & Ireland & Carpenter \\
\hline Crawford & Sergeant & 19 & England & 1786 & England & Labourer \\
\hline Connett & Corporal & 39 & England & 1805 & Ireland & Labourer \\
\hline Campbell & Private & 17 & Ireland & 1797 & Spain & Labourer \\
\hline Campbell & Private & 9 & Ireland & 1803 & England & Labourer \\
\hline Carlon & Corporal & 20 & Ireland & 1792 & Ireland & Weaver \\
\hline Charlesworth & Corporal & 20 & Ireland & 1808 & Ireland & Labourer \\
\hline Cooper & Private & 19 & England & 1811 & England & Labourer \\
\hline Carrol & Private & 21 & Ireland & 1807 & Ireland & Weaver \\
\hline Clarke & Private & 20 & England & 1811 & England & Labourer \\
\hline Cundy & Private & 26 & England & 1806 & Ireland & Carpenter \\
\hline Crofs & Private & 20 & England & 1806 & Ireland & Weaver \\
\hline Conroy & Corporal & 20 & Ireland & 1808 & Ireland & Labourer \\
\hline Connell & Private & 19 & Ireland & 1805 & Ireland & Labourer \\
\hline Caddell & Private & 16 & Ireland & 1807 & Ireland & Nailer \\
\hline
\end{tabular}


The Journal of Military History and Defence Studies

\begin{tabular}{|c|c|c|c|c|c|c|}
\hline Cusie & Sergeant & 32 & Ireland & 1811 & Ireland & Weaver \\
\hline Connors & Corporal & 47 & Ireland & 1792 & Ireland & Mason \\
\hline Chappell & Private & 20 & Unknown & 1806 & Ireland & Labourer \\
\hline Campbhele & Corporal & 17 & Ireland & 1806 & Ireland & W'Smith \\
\hline Clarke & Private & 22 & Ireland & 1806 & Ireland & Calico Printer \\
\hline Cooper & Private & 38 & Ireland & 1809 & Ireland & Weaver \\
\hline Connors & Corporal & 21 & Ireland & 1811 & England & Labourer \\
\hline Cannon & Private & 28 & Ireland & 1808 & Ireland & Miller \\
\hline Clarke & Private & Unknown & Unknown & 1803 & Unknown & Unknown \\
\hline Clarke & Private & 17 & Ireland & 1806 & Ireland & Labourer \\
\hline Condon & Private & 20 & Ireland & 1811 & England & Labourer \\
\hline Crouch & Private & 19 & England & 1811 & England & Carpenter \\
\hline Cruise & Private & 29 & England & 1804 & Ireland & Labourer \\
\hline Condon & Private & 30 & England & 1806 & England & Labourer \\
\hline Cox & Private & 18 & Ireland & 1811 & Ireland & Labourer \\
\hline Cozens & Private & 20 & England & 1812 & England & Labourer \\
\hline Connor & Private & 23 & England & 1812 & Ireland & Labourer \\
\hline Connor & Private & 28 & Ireland & 1812 & England & Labourer \\
\hline Clarke & Private & 26 & Ireland & 1812 & England & Labourer \\
\hline Connell & Private & 17 & Ireland & 1812 & Ireland & Labourer \\
\hline Corcoran & Private & 35 & Ireland & 1812 & England & Labourer \\
\hline Couse & Private & 20 & England & 1812 & England & Shoemaker \\
\hline Cooke & Private & 25 & Unknown & 1805 & Ireland & Weaver \\
\hline Campbell & Private & 33 & Ireland & 1806 & Ireland & Weaver \\
\hline Casey & Private & 20 & Ireland & 1805 & Ireland & Labourer \\
\hline Coffin & Sergeant & 17 & Unknown & 1805 & Ireland & Labourer \\
\hline Corfield & Private & 19 & England & 1803 & England & Labourer \\
\hline Cole & Private & 23 & England & 1811 & Unknown & Gozdwesier \\
\hline Caulfield & Private & 17 & Ireland & 1812 & Ireland & Labourer \\
\hline Cavanagh & Private & 18 & Ireland & 1812 & Ireland & Labourer \\
\hline Cahill & Private & 32 & Ireland & 1812 & England & Cooper \\
\hline Cantwele & Private & 20 & Ireland & 1812 & Ireland & Labourer \\
\hline Cumin & Private & 18 & Ireland & 1812 & Ireland & Labourer \\
\hline Connor & Private & 18 & England & 1813 & England & Labourer \\
\hline Campbell & Private & 18 & Ireland & 1813 & Ireland & Weaver \\
\hline Chatterley & Private & 21 & England & 1813 & Unknown & Unknown \\
\hline Conroy & Private & 19 & England & 1813 & Unknown & Labourer \\
\hline Conoughton & Private & 20 & England & 1813 & England & Labourer \\
\hline Collins & Private & 17 & England & 1813 & England & Butcher \\
\hline Condon & Private & 20 & Ireland & 1813 & Ireland & Unknown \\
\hline Cloud & Private & 29 & England & 1804 & Ireland & Labourer \\
\hline Connolly & Private & 18 & Ireland & 1807 & Ireland & Taylor \\
\hline Connolly & Private & 19 & Ireland & 1806 & Ireland & Polisher \\
\hline Connor & Private & 16 & Ireland & 1806 & Ireland & Labourer \\
\hline
\end{tabular}


The Irish soldier in the British Army in the Peninsula Campaign

\begin{tabular}{|c|c|c|c|c|c|c|}
\hline Campbell & Private & 18 & Ireland & 1807 & Ireland & Unknown \\
\hline Carberry & Private & 15 & Ireland & 1813 & Ireland & Weaver \\
\hline Campbell & Private & 21 & Ireland & 1807 & Unknown & Labourer \\
\hline Chew & Private & 15 & England & 1814 & England & Labourer \\
\hline Carrol & Private & 18 & Ireland & 1814 & Ireland & Taylor \\
\hline Cole & Private & 18 & England & 1814 & England & Labourer \\
\hline Connors & Private & 18 & Ireland & 1816 & Ireland & Labourer \\
\hline Clarke & Private & 29 & Ireland & 1807 & Ireland & Weaver \\
\hline Cunningham & Private & Nil & Unknown & 1815 & Ireland & Unknown \\
\hline Davis & Sergeant & 19 & England & 1804 & Ireland & Labourer \\
\hline Davis & Private & 34 & England & 1811 & England & Wheelwright \\
\hline Doyle & Private & 21 & Ireland & 1811 & Ireland & Labourer \\
\hline Dennis & Corporal & 21 & England & 1806 & Ireland & Miner \\
\hline Dixon & Private & 22 & Ireland & 1811 & Ireland & Labourer \\
\hline Darch & Corporal & 27 & England & 1806 & Ireland & Labourer \\
\hline Duck & Private & 18 & Ireland & 1811 & England & Labourer \\
\hline Dougherty & Corporal & 22 & Ireland & 1792 & England & Soldier \\
\hline Donnelly & Corporal & 34 & Ireland & 1796 & England & Weaver \\
\hline D Pat & Private & Unknown & Unknown & Unknown & Unknown & Unknown \\
\hline Darrock & Corporal & 16 & England & 1803 & Ireland & Labourer \\
\hline Doonar & Sergeant & 20 & Ireland & 1811 & England & Labourer \\
\hline Doake & Private & 22 & Ireland & 1808 & Ireland & Weaver \\
\hline Donnelly & Private & 12 & England & 1809 & England & Labourer \\
\hline Donnelly & Corporal & 26 & Ireland & 1786 & Ireland & Taylor \\
\hline Dredge & Private & 21 & England & 1811 & England & Labourer \\
\hline Devitt & Private & 30 & Ireland & 1809 & Ireland & Labourer \\
\hline Dwyre & Private & 28 & Ireland & 1811 & England & Taylor \\
\hline Donnelly & Private & 25 & Ireland & 1811 & England & Weaver \\
\hline Develin & Private & 20 & Ireland & 1811 & Ireland & Labourer \\
\hline Deacon & Private & 25 & England & 1804 & Ireland & Sawyer \\
\hline Devany & Private & 22 & Ireland & 1812 & England & Taylor \\
\hline Dogherty & Private & 21 & Ireland & 1812 & England & Labourer \\
\hline Duffecy & Private & 18 & Ireland & 1812 & England & Labourer \\
\hline Dinkei & Private & 28 & German & 1812 & England & Labourer \\
\hline Dunn & Private & 19 & Ireland & 1806 & Ireland & Weaver \\
\hline Devereaux & Private & 18 & Ireland & 1805 & Ireland & Wheelwright \\
\hline Dougherty & Private & 19 & Ireland & 1812 & Ireland & Labourer \\
\hline Doolan & Private & 28 & Ireland & 1808 & England & Labourer \\
\hline Donnellan & Private & 18 & Ireland & 1812 & England & Labourer \\
\hline Dunn & Private & 23 & Ireland & 1812 & England & Stonecutter \\
\hline Davy & Private & 21 & England & 1812 & England & Limemaker \\
\hline Drew & Private & 20 & Ireland & 1812 & Ireland & Shoemaker \\
\hline Dillon & Private & 17 & Ireland & 1812 & Ireland & Labourer \\
\hline Duffy & Private & 19 & Ireland & 1806 & Ireland & Labourer \\
\hline
\end{tabular}


The Journal of Military History and Defence Studies

\begin{tabular}{|c|c|c|c|c|c|c|}
\hline Duffy & Private & 20 & Ireland & 1812 & England & Labourer \\
\hline Dempsey & Private & 28 & Ireland & 1811 & England & Carpenter \\
\hline Duffy & Private & 16 & Ireland & 1813 & Ireland & Taylor \\
\hline Davey & Private & 35 & England & 1813 & England & Joiner \\
\hline Dwyre & Private & 27 & Ireland & 1813 & Ireland & Labourer \\
\hline Dewson & Private & 17 & England & 1804 & Ireland & Labourer \\
\hline Elliot & Private & 30 & England & 1805 & Ireland & Plaisterer \\
\hline English & Private & 25 & Ireland & 1811 & England & Labourer \\
\hline Edwards & Private & 27 & England & 1812 & England & Bsmith \\
\hline Ewence & Private & 18 & England & 1812 & England & Labourer \\
\hline Ellis & Private & 30 & England & 1812 & Unknown & Labourer \\
\hline Eyeish & Private & 18 & England & 1813 & England & Labourer \\
\hline Elliot & Private & 19 & Ireland & 1814 & England & Labourer \\
\hline Emerson & Private & 14 & Ireland & 1814 & Ireland & Labourer \\
\hline Fullam & Private & 13 & Ireland & 1807 & Ireland & Weaver \\
\hline Flowers & Private & 23 & England & 1806 & Ireland & Plaisterer \\
\hline Fox & Private & 29 & Ireland & 1811 & England & Labourer \\
\hline Fawcett & Sergeant & 23 & Ireland & 1808 & Ireland & Weaver \\
\hline Fallon & Corporal & 20 & Ireland & 1811 & England & Labourer \\
\hline Fogerty & Private & 18 & Ireland & 1806 & Ireland & Labourer \\
\hline Ferguson & Sergeant & 18 & Scotland & 1789 & Scotland & Weaver \\
\hline Foden & Corporal & 17 & England & 1773 & Ireland & Whitesmith \\
\hline Unknown & Private & 16 & Ireland & 1808 & Ireland & Labourer \\
\hline Fox & Private & 22 & Ireland & 1811 & England & Labourer \\
\hline Francis & Private & 21 & England & 1804 & Ireland & Miner \\
\hline Finley & Private & 21 & Ireland & 1811 & Ireland & Labourer \\
\hline Flannigan & Private & 25 & Ireland & 1812 & Ireland & Labourer \\
\hline Flaherty & Private & 23 & Ireland & 1805 & Ireland & Labourer \\
\hline Frieth & Private & 30 & England & 1798 & England & Labourer \\
\hline Feagan & Private & 33 & Ireland & 1812 & England & Labourer \\
\hline Fisher & Private & 16 & England & 1812 & England & Labourer \\
\hline Fisher & Private & 34 & England & 1812 & England & Miner \\
\hline Fitzgibbon & Private & 22 & Ireland & 1814 & Ireland & Labourer \\
\hline Farnan & Private & 17 & Ireland & 1812 & Ireland & Labourer \\
\hline Fogerty & Private & 21 & Ireland & 1812 & Ireland & Labourer \\
\hline Foy & Private & 17 & Ireland & 1813 & Ireland & Labourer \\
\hline Finegan & Private & 16 & Ireland & 1813 & Ireland & Labourer \\
\hline Fielding & Private & 22 & Ireland & 1813 & Ireland & Labourer \\
\hline Fogerty & Private & 18 & Ireland & 1814 & Ireland & Taylor \\
\hline Fisher & Private & 35 & England & 1814 & England & Cordwinder \\
\hline Fennall & Private & 17 & England & 1814 & England & Hatter \\
\hline Forward & Private & 19 & England & 1814 & Ireland & Taylor \\
\hline Gurney & Sergeant & 25 & England & 1809 & Ireland & Soldier \\
\hline Graham & Private & 24 & Ireland & 1806 & Ireland & Weaver \\
\hline
\end{tabular}


The Irish soldier in the British Army in the Peninsula Campaign

\begin{tabular}{|c|c|c|c|c|c|c|}
\hline Greene & Private & 24 & Ireland & 1811 & Ireland & Labourer \\
\hline Gillespie & Private & 14 & Ireland & 1807 & Ireland & Sadler \\
\hline Grenham & Private & 22 & England & 1806 & Ireland & Labourer \\
\hline Guynan & Sergeant & 28 & Ireland & 1805 & Ireland & Mason \\
\hline Guinar & Private & 20 & England & 1811 & England & Labourer \\
\hline Gaffney & Corporal & 21 & Ireland & 1811 & England & Brogue Maker \\
\hline Greene & Sergeant & 23 & England & 1805 & England & Weaver \\
\hline Gribble & Private & 16 & England & 1804 & Ireland & Labourer \\
\hline Gibson & Private & 32 & Ireland & 1811 & England & Painter \\
\hline Gannon & Private & 28 & Ireland & 1812 & Ireland & Weaver \\
\hline Giles & Corporal & 31 & England & 1805 & Ireland & Rope Maker \\
\hline Garthlany & Private & 35 & Ireland & 1812 & England & Servant \\
\hline Grant & Private & 25 & Scotland & 1812 & England & Nailer \\
\hline Gill & Private & 17 & Scotland & 1812 & Ireland & Labourer \\
\hline Glancy & Private & 17 & Ireland & 1812 & England & Weaver \\
\hline Gallaher & Private & 23 & Ireland & 1805 & Ireland & Slater \\
\hline Grady & Private & 29 & Ireland & 1812 & England & Labourer \\
\hline Galvin & Private & 22 & Ireland & 1812 & Ireland & Clerk \\
\hline Garvey & Private & 18 & Ireland & 1812 & Ireland & Labourer \\
\hline Gorman & Private & 17 & Ireland & 1812 & Ireland & Labourer \\
\hline Gannon & Private & 16 & Ireland & 1812 & Ireland & Labourer \\
\hline Galloway & Private & 20 & Ireland & 1812 & Ireland & Labourer \\
\hline Gilbert & Private & 30 & England & 1813 & England & Labourer \\
\hline Guilliame & Private & 15 & England & 1813 & England & Hosier \\
\hline Grehan & Private & 20 & England & 1813 & England & Labourer \\
\hline Goodman & Private & 29 & England & 1813 & England & Chairmaker \\
\hline Green & Private & 15 & England & 1813 & England & Labourer \\
\hline Goodfellow & Private & 18 & England & 1804 & Ireland & Carpenter \\
\hline Green & Private & 26 & England & 1813 & England & Carpenter \\
\hline Gready & Sergeant & 25 & Ireland & 1805 & Ireland & Labourer \\
\hline Gilbert & Private & 21 & England & 1813 & England & Labourer \\
\hline Glover & Private & 16 & England & 1813 & England & Slater \\
\hline Grimes & Private & 18 & Ireland & 1807 & Ireland & Labourer \\
\hline Hammer & Corporal & 21 & England & 1804 & Ireland & Labourer \\
\hline Higgins & Corporal & 34 & England & 1811 & England & Taylor \\
\hline Hart & Private & 28 & Ireland & 1811 & England & Tanman \\
\hline Hayes & Corporal & 20 & Ireland & 1806 & Ireland & Labourer \\
\hline Haycroft & Private & 36 & England & 1804 & Ireland & Wheelwright \\
\hline Hanrahan & Private & 28 & Ireland & 1811 & England & Servant \\
\hline Hollis & Private & 17 & Ireland & 1811 & England & Cabinetmaker \\
\hline Hawkins & Private & 23 & England & 1805 & Ireland & Smith \\
\hline Harness & Private & 18 & England & 1805 & Ireland & Labourer \\
\hline Hunt Pat & Private & 30 & Ireland & 1811 & England & Labourer \\
\hline Hunt Michael & Private & 22 & Ireland & 1811 & England & Labourer \\
\hline
\end{tabular}


The Journal of Military History and Defence Studies

\begin{tabular}{|c|c|c|c|c|c|c|}
\hline Hogan & Private & 27 & Ireland & 1806 & Ireland & Gozdwesier \\
\hline Hardiman & Private & 14 & Ireland & 1806 & Ireland & Labourer \\
\hline Harvey & Private & 16 & England & 1806 & Ireland & Labourer \\
\hline Hynchy & Private & 36 & Ireland & 1806 & Ireland & Tailor \\
\hline Hickey & Corporal & 22 & Ireland & 1808 & Ireland & Tailor \\
\hline Hardiman & Private & 17 & Ireland & 1806 & Ireland & Labourer \\
\hline Heagney & Private & 19 & Ireland & 1811 & England & Mason \\
\hline Hobson & Sergeant & 28 & England & 1798 & England & Hatter \\
\hline Hawkins & Private & Unknown & Unknown & 1803 & Unknown & Unknown \\
\hline Hare & Private & 19 & Ireland & 1811 & England & Weaver \\
\hline Holman & Private & 25 & England & 1803 & England & Miner \\
\hline Hamley & Private & 28 & England & 1812 & England & Miner \\
\hline Harry & Private & 19 & Scotland & 1812 & England & Labourer \\
\hline Halliman & Private & 34 & Ireland & 1801 & Ireland & Labourer \\
\hline Hogg & Private & 21 & Ireland & 1812 & England & Labourer \\
\hline Harrington & Private & 18 & Ireland & 1812 & England & Labourer \\
\hline Horan & Private & 19 & Ireland & 1812 & England & Labourer \\
\hline Healy & Private & 28 & Ireland & 1812 & England & Labourer \\
\hline Hallman & Private & 22 & England & 1812 & England & Labourer \\
\hline Harris & Private & 24 & England & 1812 & England & Labourer \\
\hline Haymes & Private & 20 & England & 1812 & England & Labourer \\
\hline House & Private & 21 & England & 1812 & England & Gozdwesier \\
\hline Hawison & Private & 20 & Ireland & 1808 & Ireland & Weaver \\
\hline Holloway & Private & 30 & Ireland & 1805 & Ireland & Woolcomber \\
\hline Hare & Private & 21 & England & 1803 & England & Labourer \\
\hline Hollis & Private & 40 & England & 1806 & Ireland & Hops \\
\hline Husbands & Private & 25 & England & 1813 & England & Labourer \\
\hline Hamilton & Private & 26 & England & 1813 & England & Labourer \\
\hline Hopkins & Private & 14 & England & 1813 & England & Labourer \\
\hline Hurst & Private & 31 & England & 1813 & England & Cottonweaver \\
\hline Hughes & Private & 19 & Ireland & 1813 & England & Labourer \\
\hline Higgins & Private & 21 & Ireland & 1813 & England & Labourer \\
\hline Hoare & Private & 17 & England & 1813 & England & Taylor \\
\hline Hancock & Private & 32 & England & 1813 & England & Labourer \\
\hline Hancock & Private & 30 & England & 1813 & Ireland & Labourer \\
\hline Hanley & Private & 15 & Ireland & 1813 & Ireland & Servant \\
\hline Haynes & Private & 16 & Ireland & 1813 & Ireland & Labourer \\
\hline Haydon & Private & 19 & England & 1803 & England & Labourer \\
\hline Humphrey & Private & 18 & England & 1812 & England & Labourer \\
\hline Harrod & Private & 25 & England & 1804 & Ireland & Shoemaker \\
\hline Hall & Private & 18 & Ireland & 1806 & England & Weaver \\
\hline Hicks & Private & Unknown & Unknown & Unknown & Unknown & Unknown \\
\hline Hughes & Private & 15 & Ireland & 1813 & Ireland & Labourer \\
\hline Hutchinson & Private & Unknown & Unknown & Unknown & Unknown & Unknown \\
\hline
\end{tabular}


The Irish soldier in the British Army in the Peninsula Campaign

\begin{tabular}{|c|c|c|c|c|c|c|}
\hline Huxter & Private & 19 & England & 1813 & Ireland & Labourer \\
\hline Hart & Private & 15 & Ireland & 1813 & Ireland & Labourer \\
\hline Hawkins & Private & 17 & Ireland & 1813 & Ireland & Clerk \\
\hline Harris & Private & 34 & England & 1814 & England & Labourer \\
\hline Hartigan & Private & 21 & Ireland & 1814 & Ireland & Labourer \\
\hline Hancock & Private & 20 & England & 1804 & Ireland & Shoemaker \\
\hline Hammer & Private & 18 & England & 1805 & England & Labourer \\
\hline Hiscock & Private & 18 & England & 1804 & Ireland & Labourer \\
\hline Haggerty & Private & 14 & Ireland & 1806 & England & Labourer \\
\hline Hopkins & Private & 18 & England & 1804 & Ireland & Labourer \\
\hline Irwine & SM/ QMS & 20 & Ireland & 1807 & Ireland & Weaver \\
\hline Johnson & Private & 15 & England & 1811 & England & Cordwinder \\
\hline Jones & Sergeant & 24 & England & 1794 & England & Labourer \\
\hline Jackway & Sergeant & 23 & England & 1790 & England & Butcher \\
\hline Jacobs & Sergeant & 33 & England & 1805 & England & Labourer \\
\hline Johnson & Corporal & 38 & Ireland & 1799 & Ireland & Labourer \\
\hline Jones & Private & 24 & England & 1804 & Ireland & Labourer \\
\hline Jefford & Private & 15 & England & 1811 & England & Labourer \\
\hline Jefferies & Corporal & 19 & England & 1812 & England & Unknown \\
\hline Jackson & Private & 28 & Ireland & 1811 & England & Yeoman \\
\hline Jones & Private & 16 & England & 1811 & England & Mason \\
\hline Jentle & Private & 15 & Ireland & 1806 & Ireland & Taylor \\
\hline Jones & Private & 19 & Ireland & 1812 & England & Taylor \\
\hline Jnnis & Private & 24 & England & 1812 & England & Hairdyer \\
\hline Johnson & Private & 21 & England & 1812 & England & Labourer \\
\hline Jeffrey & Private & 19 & England & 1812 & Unknown & Labourer \\
\hline Johnson & Private & 22 & England & 1813 & England & Labourer \\
\hline $\mathrm{Jab}$ & Private & 33 & England & 1812 & England & Labourer \\
\hline Jones & Private & 18 & Scotland & 1813 & England & Stonemason \\
\hline Jefferies & Private & 22 & England & 1804 & Ireland & Labourer \\
\hline Johnston, Irvine & Private & 27 & Ireland & 1814 & England & Labourer \\
\hline Johnston, Arthur & Private & 25 & Ireland & 1814 & England & Labourer \\
\hline Johnston, Robert & Private & 21 & Ireland & 1814 & England & Farrier \\
\hline James & Private & 22 & England & 1814 & England & Labourer \\
\hline Kennedy & Sergeant & 32 & Ireland & 1807 & England & Painter \\
\hline Kennedy & Private & 22 & England & 1811 & England & Clockmaker \\
\hline Kerr & Sergeant & 18 & Ireland & 1808 & Ireland & Labourer \\
\hline King & Sergeant & 26 & England & 1805 & Ireland & Cordwinder \\
\hline Kitchen & Corporal & 30 & England & 1805 & Ireland & Labourer \\
\hline Keating & Private & 39 & Ireland & 1805 & Ireland & Weaver \\
\hline Kelly & Private & 22 & Ireland & 1811 & England & Cordwinder \\
\hline Kiernan & Private & 14 & Ireland & 1807 & Ireland & Labourer \\
\hline Knight & Private & 26 & Ireland & 1808 & Ireland & Taylor \\
\hline Keeffe & Private & 24 & Ireland & 1811 & England & Taylor \\
\hline
\end{tabular}


The Journal of Military History and Defence Studies

\begin{tabular}{|c|c|c|c|c|c|c|}
\hline Kellion & Private & 21 & England & 1811 & England & Labourer \\
\hline Keating & Corporal & 18 & Ireland & 1805 & Ireland & Labourer \\
\hline Keating & Corporal & 16 & Ireland & 1806 & Ireland & Labourer \\
\hline Keagan & Private & 36 & England & 1798 & Ireland & Labourer \\
\hline Keaghan & Private & 19 & Ireland & 1811 & Ireland & Labourer \\
\hline Kinsman & Private & 17 & England & 1812 & England & Labourer \\
\hline Keffee & Private & 19 & Ireland & 1812 & Ireland & Labourer \\
\hline Kean & Private & 25 & Ireland & 1812 & Ireland & Labourer \\
\hline Kemple & Private & 20 & Ireland & 1812 & Ireland & Labourer \\
\hline Knight & Private & 22 & England & 1812 & England & Farrier \\
\hline Kelly & Private & 24 & Ireland & 1805 & Unknown & Labourer \\
\hline Kennedy & Private & 18 & Ireland & 1812 & Ireland & Taylor \\
\hline Kane & Private & 16 & Ireland & 1810 & Unknown & Labourer \\
\hline Koohoone & Private & 19 & Ireland & 1807 & Ireland & Labourer \\
\hline King & Private & 19 & Ireland & 1813 & Ireland & Weaver \\
\hline Kelly & Private & 16 & Ireland & 1813 & Ireland & Servant \\
\hline Kenny & Private & 15 & Ireland & 1813 & Ireland & Labourer \\
\hline Keelan & Private & 29 & Ireland & 1807 & Ireland & Labourer \\
\hline Ketterick & Private & 23 & Ireland & 1806 & Ireland & Labourer \\
\hline Kennedy & Private & 15 & Ireland & Unknown & Ireland & Labourer \\
\hline Keating & Private & 18 & Ireland & 1807 & Ireland & Labourer \\
\hline Kearns & Private & 28 & Ireland & 1813 & Ireland & Servant \\
\hline Locke & Sergeant & 23 & England & 1806 & Ireland & Hornworker \\
\hline Lovelocke & Sergeant & 25 & England & 1794 & England & Labourer \\
\hline Livingston & Private & 14 & Ireland & 1807 & Ireland & Unknown \\
\hline Larkin & Private & 20 & Ireland & 1811 & Ireland & Labourer \\
\hline Laity & Sergeant & 29 & England & 1805 & Ireland & Miner \\
\hline Lovell & Corporal & 30 & England & 1805 & Ireland & Miner \\
\hline Lewis & Private & 20 & America & 1806 & Ireland & Labourer \\
\hline Lane & Private & 18 & Ireland & 1805 & England & Blacksmith \\
\hline Langsberry & Sergeant & 26 & England & 1805 & Ireland & Bricklayer \\
\hline Lynch & Private & 23 & Ireland & 1808 & Ireland & Hairdyer \\
\hline Lesley & Private & 19 & Ireland & 1811 & England & Labourer \\
\hline Loughlin & Private & 22 & Ireland & 1810 & Ireland & Sawyer \\
\hline Leonard & Private & 16 & Ireland & 1812 & Ireland & Labourer \\
\hline Lentern & Private & 33 & England & 1812 & England & Labourer \\
\hline Lonnin & Private & 16 & Ireland & 1812 & England & Shoemaker \\
\hline Lidyeara & Private & 29 & England & 1812 & England & Butcher \\
\hline Lindsey & Private & 21 & England & 1812 & England & Unknown \\
\hline Lee & Private & 24 & England & 1811 & England & Labourer \\
\hline Lugg & Private & 22 & England & 1811 & England & Cottonweaver \\
\hline Loads & Private & 19 & England & 1812 & England & Labourer \\
\hline Lynch & Private & 25 & Ireland & 1806 & England & Weaver \\
\hline Langan & Private & 19 & Ireland & 1813 & England & Labourer \\
\hline
\end{tabular}


The Irish soldier in the British Army in the Peninsula Campaign

\begin{tabular}{|c|c|c|c|c|c|c|}
\hline LeBeuf & Private & 25 & Unknown & 1813 & England & Unknown \\
\hline Lanasey & Private & 20 & Ireland & 1813 & Ireland & Labourer \\
\hline Leitner & Private & 35 & Prussia & 1813 & England & Miller \\
\hline Lavery & Private & 18 & Ireland & 1813 & Ireland & Labourer \\
\hline Lanis & Private & 21 & England & 1805 & Ireland & Labourer \\
\hline Lafferty & Private & 19 & Ireland & 1802 & Ireland & Hocklar \\
\hline Morphy & Sergeant & 36 & Ireland & 1806 & Ireland & Weaver \\
\hline Milead & Sergeant & 26 & Scotland & 1790 & Scotland & Weaver \\
\hline Maxwell & Private & 17 & Ireland & 1806 & Ireland & Coachmaker \\
\hline Mahony & Private & 26 & Ireland & 1802 & Ireland & Cordwinder \\
\hline Matrin & Private & 20 & Ireland & 1806 & Ireland & Labourer \\
\hline May & Private & 16 & England & 1811 & England & Taylor \\
\hline Musgrave & Private & 30 & England & 1806 & Ireland & Labourer \\
\hline Muxworthy & Private & 30 & England & 1805 & Ireland & Labourer \\
\hline Murphy & Sergeant & 30 & Ireland & 1806 & Ireland & Labourer \\
\hline Morrifsey & Private & 25 & Ireland & 1802 & Ireland & Labourer \\
\hline Millar & Private & 12 & Ireland & 1806 & Ireland & Labourer \\
\hline McMahon & Private & 19 & Ireland & 1811 & Ireland & Woolcomber \\
\hline McDermott & Private & 22 & Ireland & 1806 & Ireland & Labourer \\
\hline McDonald & Private & 22 & Ireland & 1811 & England & Labourer \\
\hline McEagan & Corporal & 30 & Ireland & 1805 & Ireland & Weaver \\
\hline Murphy & Private & 33 & Ireland & 1811 & Ireland & Labourer \\
\hline McCudden & Private & 19 & Ireland & 1807 & Ireland & Labourer \\
\hline Matthews & Private & Unknown & Unknown & 1811 & Unknown & Unknown \\
\hline Maunder & Private & 22 & England & 1804 & Ireland & Labourer \\
\hline Milligan & Private & 24 & Ireland & 1798 & Ireland & Weaver \\
\hline McKeon & Sergeant & 29 & Ireland & 1793 & Ireland & Labourer \\
\hline Morrow & Private & 24 & Ireland & 1806 & Ireland & Weaver \\
\hline Martin & Private & 16 & England & 1811 & England & Labourer \\
\hline McDonagh & Private & 25 & Ireland & 1811 & England & Labourer \\
\hline McKeon & Corporal & 21 & Ireland & 1811 & England & Labourer \\
\hline McGrath & Private & 21 & Ireland & 1811 & Ireland & Weaver \\
\hline McCabe & Private & 18 & Ireland & 1811 & Ireland & Weaver \\
\hline McCarthy & Private & 28 & Ireland & 1811 & Ireland & Labourer \\
\hline McNealy & Private & 23 & Ireland & 1812 & England & Labourer \\
\hline Mofs & Private & 23 & England & 1812 & England & Taylor \\
\hline Murray & Private & 25 & Ireland & 1812 & Ireland & Labourer \\
\hline Matthews & Private & 18 & Ireland & 1806 & Ireland & Labourer \\
\hline Meaden & Private & 20 & England & 1812 & England & Labourer \\
\hline Myers & Private & 19 & Ireland & 1808 & Ireland & Taylor \\
\hline Mercer & Private & 20 & Ireland & 1807 & Ireland & Weaver \\
\hline McDonald & Private & 18 & Ireland & 1806 & Ireland & Cottonspinner \\
\hline McDonnelan & Private & 21 & Ireland & 1812 & Ireland & Taylor \\
\hline McShane & Private & 20 & Ireland & 1812 & Ireland & Weaver \\
\hline
\end{tabular}


The Journal of Military History and Defence Studies

\begin{tabular}{|c|c|c|c|c|c|c|}
\hline Murray Henry & Private & 28 & Ireland & 1812 & England & Labourer \\
\hline Murray Hugh & Private & 18 & Ireland & 1812 & England & Labourer \\
\hline McDaniel & Private & 23 & Ireland & 1812 & England & Labourer \\
\hline McDermott & Private & 21 & Ireland & 1812 & England & Student \\
\hline Mooney & Private & 24 & Ireland & 1812 & England & Labourer \\
\hline Minara & Private & 41 & England & 1806 & Ireland & Sawyer \\
\hline McGaw & Private & 25 & England & 1805 & Ireland & Weaver \\
\hline McLoughlin & Private & 19 & Ireland & 1812 & England & Labourer \\
\hline Mears & Private & 26 & Ireland & 1812 & England & Weaver \\
\hline Unknown & Private & 18 & England & 1812 & England & Weaver \\
\hline Malone & Private & 24 & Ireland & 1812 & Ireland & Labourer \\
\hline Mills & Private & 15 & England & 1812 & England & Labourer \\
\hline Mellish & Private & 24 & England & 1804 & Ireland & Unknown \\
\hline Murphy & Private & 14 & Ireland & 1807 & Ireland & Hairdyer \\
\hline Milton & Private & 20 & England & 1804 & Ireland & Woolcomber \\
\hline Myers & Private & 17 & Ireland & 1812 & Ireland & Labourer \\
\hline Millard & Private & 22 & England & 1805 & England & Unknown \\
\hline McAuley & Private & 21 & Ireland & 1812 & Ireland & Labourer \\
\hline Mullin & Private & 16 & Ireland & 1812 & Ireland & Taylor \\
\hline Marks & Private & 18 & Ireland & 1812 & Ireland & Butcher \\
\hline McDonnell & Private & 38 & Scotland & 1806 & Ireland & Labourer \\
\hline McMullin & Private & 31 & Scotland & 1813 & England & Hailster \\
\hline McCall & Private & 24 & Ireland & 1813 & Ireland & Weaver \\
\hline Melody & Private & 17 & Ireland & 1812 & Ireland & Labourer \\
\hline Mitchell & Private & 22 & England & 1813 & England & Glazier \\
\hline McGovernan & Private & 18 & Ireland & 1813 & England & Labourer \\
\hline Mount & Private & 22 & England & 1813 & Ireland & Labourer \\
\hline McCullom & Private & 21 & Ireland & 1812 & England & Bricklayer \\
\hline Marshall & Private & 15 & Ireland & 1813 & Ireland & Labourer \\
\hline McDaniel & Private & 15 & Ireland & 1813 & Ireland & Labourer \\
\hline Mulhollin & Private & 16 & Ireland & 1813 & Ireland & Labourer \\
\hline Morrifsey & Private & Unknown & Unknown & Unknown & Unknown & Unknown \\
\hline McGuire & Private & 14 & Ireland & 1807 & Ireland & Labourer \\
\hline McArdle & Private & 18 & Ireland & 1807 & Ireland & Shoemaker \\
\hline Morris & Private & 30 & England & 1806 & Ireland & Labourer \\
\hline McGee & Private & 15 & Ireland & 1813 & Ireland & Weaver \\
\hline McEntagent & Private & 18 & Ireland & 1813 & Ireland & Weaver \\
\hline Martin & Private & 23 & Ireland & 1808 & Ireland & Labourer \\
\hline Murray & Private & 18 & Ireland & 1813 & Ireland & Bricklayer \\
\hline Matthews & Private & 25 & England & 1815 & England & Labourer \\
\hline McAllister & Private & Unknown & Unknown & Unknown & Unknown & Unknown \\
\hline Magenis & Private & 16 & Ireland & 1814 & Ireland & Taylor \\
\hline McFadden & Private & 15 & Ireland & 1814 & Ireland & Labourer \\
\hline McGormley & Private & 15 & Ireland & 1814 & Ireland & Labourer \\
\hline
\end{tabular}


The Irish soldier in the British Army in the Peninsula Campaign

\begin{tabular}{|c|c|c|c|c|c|c|}
\hline Magenis & Private & 15 & Ireland & 1814 & Ireland & Labourer \\
\hline Marrish & Private & 22 & Ireland & 1805 & Ireland & Labourer \\
\hline McAuley & Private & 22 & Ireland & 1814 & Ireland & Labourer \\
\hline Major & Private & 17 & England & 1814 & England & Labourer \\
\hline Moore & Private & 25 & Unknown & 1798 & Unknown & Unknown \\
\hline Newberry & Sergeant & 24 & England & 1806 & Ireland & Basketmaker \\
\hline Narey & Private & 25 & Ireland & 1811 & England & Labourer \\
\hline Nicholson & Private & 18 & Ireland & 1812 & England & Weaver \\
\hline Nevin & Private & 20 & Ireland & 1812 & England & Labourer \\
\hline Neill & Private & 16 & Ireland & 1812 & Ireland & Weaver \\
\hline Naughton & Private & 32 & Ireland & 1812 & England & Taylor \\
\hline Newgent & Private & 18 & England & 1813 & England & Labourer \\
\hline Newitt & Private & 18 & Ireland & 1813 & Ireland & Carpenter \\
\hline Nappein & Private & 23 & Ireland & 1802 & Ireland & Labourer \\
\hline Neill & Private & Unknown & Unknown & Unknown & Unknown & Unknown \\
\hline Nowlan & Private & 18 & Ireland & 1813 & Ireland & Servant \\
\hline Norergs & Private & 15 & England & 1813 & England & Weaver \\
\hline O'Connors & Sergeant & 28 & Ireland & 1811 & England & Gardener \\
\hline O'Byrne & Sergeant & 23 & Ireland & 1806 & Ireland & Musician \\
\hline O'Brien & Private & 18 & Ireland & 1811 & Ireland & Taylor \\
\hline Osmomd & Sergeant & 31 & Ireland & 1806 & Ireland & Mason \\
\hline Oliver & Sergeant & 28 & England & 1805 & Ireland & Labourer \\
\hline O'Neill & Private & 19 & England & 1811 & England & Labourer \\
\hline O'Brien & Corporal & 23 & Ireland & 1811 & England & Shoemaker \\
\hline O'Neill & Private & 21 & Ireland & 1811 & England & Victualler \\
\hline O'Neill Charles & Private & 29 & Ireland & 1811 & Ireland & Bleacher \\
\hline Ockley & Private & 20 & England & 1812 & England & Unknown \\
\hline O'Byran & Private & 30 & Ireland & 1812 & Unknown & Painter \\
\hline Overan & Private & 18 & Ireland & 1807 & Ireland & Weaver \\
\hline O'Brian & Private & 23 & Ireland & 1815 & Ireland & Labourer \\
\hline O'Brian & Private & 16 & Ireland & 1806 & Ireland & Labourer \\
\hline Oakam & Private & 29 & England & 1806 & Ireland & Weaver \\
\hline Oakam & Private & 32 & England & 1806 & Ireland & Weaver \\
\hline Porter & Sergeant & 21 & England & 1807 & Ireland & Plumber \\
\hline Pyne & Sergeant & 22 & England & 1806 & Ireland & Plaisterer \\
\hline Palmer & Private & 28 & England & 1794 & England & Baker \\
\hline Pearce & Corporal & 25 & England & 1806 & Ireland & Bricklayer \\
\hline Perring & Private & 27 & England & 1805 & Ireland & Labourer \\
\hline Pock & Private & 28 & England & 1805 & Ireland & Labourer \\
\hline Pearce & Private & 26 & England & 1804 & Ireland & Labourer \\
\hline Pocock & Sergeant & 25 & England & 1806 & Ireland & Labourer \\
\hline Penberthy & Private & 25 & England & 1802 & England & Mason \\
\hline Parker & Private & 31 & England & 1811 & England & Glazier \\
\hline Preston & Private & 20 & England & 1811 & England & Labourer \\
\hline
\end{tabular}


The Journal of Military History and Defence Studies

\begin{tabular}{|c|c|c|c|c|c|c|}
\hline Pullen & Private & 24 & England & 1812 & England & Labourer \\
\hline Parrott & Private & 27 & England & 1805 & Ireland & Tanner \\
\hline Philips & Private & 28 & England & 1806 & Ireland & Sawyer \\
\hline Plumber & Private & 26 & England & 1803 & England & Labourer \\
\hline Pattet & Private & 20 & Ireland & 1812 & Unknown & Labourer \\
\hline Palmer & Private & 26 & England & 1812 & England & Unknown \\
\hline Pearce & Private & 28 & Ireland & 1812 & Unknown & Labourer \\
\hline Perrin & Private & 20 & England & 1811 & Ireland & Unknown \\
\hline Parsons & Private & 28 & England & 1812 & Unknown & Unknown \\
\hline Peacey & Private & 28 & England & 1813 & England & Labourer \\
\hline Prout & Private & 17 & England & 1809 & England & Labourer \\
\hline Plunkett & Private & 16 & Ireland & 1806 & Ireland & Labourer \\
\hline Perrin & Private & 19 & England & 1813 & England & Labourer \\
\hline Pepperal & Private & 23 & England & Unknown & Ireland & Labourer \\
\hline Philips & Private & 18 & England & Unknown & England & Labourer \\
\hline Quich & SM or QMS & 22 & England & 1811 & Ireland & Labourer \\
\hline Quike & Private & 19 & Ireland & 1811 & England & Labourer \\
\hline Quinn & Private & 16 & Ireland & 1811 & Ireland & Labourer \\
\hline Quinn Jason & Private & 21 & Ireland & 1812 & Ireland & Weaver \\
\hline Quinn Edward & Private & 18 & England & 1812 & Ireland & Labourer \\
\hline Rutley & Sergeant & 35 & England & 1806 & Ireland & Weaver \\
\hline Reagan & Corporal & 19 & Ireland & 1807 & Ireland & Labourer \\
\hline Reynolds & Private & 18 & Ireland & 1806 & Ireland & Labourer \\
\hline Roberts & Private & 19 & Ireland & 1796 & Unknown & Labourer \\
\hline Rodgyman & Sergeant & 28 & England & 1806 & Ireland & Shipwright \\
\hline Ryan & Private & 19 & Ireland & 1811 & Ireland & Unknown \\
\hline Ryan & Sergeant & 19 & Ireland & 1809 & Ireland & Printer \\
\hline Reed & Private & 21 & Ireland & 1808 & Ireland & Taylor \\
\hline Reilly & Sergeant & 17 & Ireland & 1811 & Ireland & Labourer \\
\hline Reed & Private & 19 & England & 1804 & Ireland & Thatcher \\
\hline Roake & Private & 18 & England & 1805 & England & Unknown \\
\hline Rowe & Private & 24 & England & 1811 & England & Labourer \\
\hline Ryan & Private & 18 & Ireland & 1811 & England & Taylor \\
\hline Ruff & Private & 24 & Ireland & 1811 & England & Mason \\
\hline Reynolds & Private & 19 & England & 1812 & Ireland & Unknown \\
\hline Reynolds, John & Private & 21 & Ireland & 1792 & Ireland & Labourer \\
\hline Rodgers & Private & 18 & Ireland & 1812 & England & Labourer \\
\hline Reays & Private & 19 & Ireland & 1812 & Ireland & Labourer \\
\hline Rose & Private & 22 & England & 1804 & Ireland & Unknown \\
\hline Redgeswood & Private & 24 & Unknown & 1813 & England & Labourer \\
\hline Rooney & Private & 16 & Ireland & 1812 & Ireland & Labourer \\
\hline Rock & Private & 17 & Ireland & 1812 & Ireland & Hozier \\
\hline Ruthesfoie & Private & 35 & Ireland & 1809 & Ireland & Labourer \\
\hline Rickett & Private & 18 & England & 1813 & England & Labourer \\
\hline
\end{tabular}


The Irish soldier in the British Army in the Peninsula Campaign

\begin{tabular}{|c|c|c|c|c|c|c|}
\hline Rafferty & Private & 15 & Ireland & 1814 & Ireland & Servant \\
\hline Sullivan & Sergeant & 24 & Ireland & 1809 & Ireland & Gunsmith \\
\hline Saunders & Private & 29 & England & 1806 & Ireland & Labourer \\
\hline Sammon & Private & 20 & Ireland & 1811 & England & Labourer \\
\hline Shields & Private & 18 & Ireland & 1806 & Ireland & Butcher \\
\hline Stevenson & Private & 18 & Ireland & 1811 & England & Labourer \\
\hline Sheppard & Sergeant & 21 & England & 1805 & Ireland & Mason \\
\hline Steele & Private & 13 & England & 1811 & England & Labourer \\
\hline Smyths & Corporal & 18 & Ireland & 1811 & Ireland & Labourer \\
\hline Streets & Private & 24 & England & 1805 & Ireland & Labourer \\
\hline Sandircock & Private & 29 & England & 1806 & England & Miner \\
\hline Sweeney & Private & 24 & Ireland & 1811 & England & Labourer \\
\hline Symonds & Sergeant & 31 & Ireland & 1805 & Ireland & Labourer \\
\hline Seaguell & Private & 35 & England & 1814 & Ireland & Labourer \\
\hline Sinon & Private & 30 & Ireland & 1811 & England & Weaver \\
\hline Shapsland & Private & 34 & England & 1806 & Ireland & Labourer \\
\hline Smyth & Private & 30 & Ireland & 1811 & England & Shoemaker \\
\hline Sabey & Private & 34 & England & 1804 & Ireland & Labourer \\
\hline Stantiford & Corporal & 22 & Unknown & 1804 & Ireland & Labourer \\
\hline Shannon & Private & 18 & Ireland & 1807 & Ireland & Weaver \\
\hline Sullivan & Private & 22 & Ireland & 1811 & England & Labourer \\
\hline Slugg & Corporal & 18 & England & Unknown & England & Scribbler \\
\hline Stoneman & Private & 24 & England & 1804 & Ireland & Labourer \\
\hline Sidnell & Private & 21 & England & 1804 & Ireland & Labourer \\
\hline Sommers & Private & 19 & Ireland & 1811 & England & Weaver \\
\hline Stevenson & Private & 18 & England & 1812 & England & Labourer \\
\hline Spry & Private & 20 & England & 1811 & Unknown & Labourer \\
\hline Sheehan & Private & 30 & Ireland & 1812 & Ireland & Victualler \\
\hline Sweeney & Private & 18 & Ireland & 1812 & England & Labourer \\
\hline Stanning & Private & 20 & England & 1812 & England & Labourer \\
\hline Smyth & Private & 33 & England & 1812 & England & Labourer \\
\hline Smyth & Private & 21 & England & 1812 & England & Labourer \\
\hline Self & Private & 21 & England & 1812 & England & Labourer \\
\hline Sowden & Private & 23 & England & Unknown & England & Labourer \\
\hline Shea & Private & 21 & Ireland & 1812 & Ireland & Labourer \\
\hline Shine & Private & 18 & Ireland & 1813 & Ireland & Labourer \\
\hline Scott & Private & 18 & England & 1795 & England & Labourer \\
\hline Steadling & Private & 24 & England & 1806 & Ireland & Weaver \\
\hline Smith & Private & 15 & Ireland & 1807 & Ireland & Labourer \\
\hline Shaw & Private & 20 & England & 1813 & England & Labourer \\
\hline Seviens & Private & 17 & England & Unknown & England & Labourer \\
\hline Smith & Private & 22 & England & 1813 & England & Carpenter \\
\hline Store & Private & Unknown & England & 1806 & Ireland & Carpenter \\
\hline Savage & Private & 26 & Ireland & 1814 & Ireland & Taylor \\
\hline
\end{tabular}


The Journal of Military History and Defence Studies

\begin{tabular}{|c|c|c|c|c|c|c|}
\hline Seymour & Private & 24 & Ireland & 1814 & Ireland & Labourer \\
\hline Sands & Private & 16 & Ireland & 1814 & Ireland & Labourer \\
\hline Smith & Private & 21 & Ireland & 1814 & Ireland & Taylor \\
\hline Simons & Private & 21 & England & 1804 & Ireland & Labourer \\
\hline Taylor & Corporal & 21 & England & 1806 & Ireland & Slater \\
\hline Turner & Sergeant & 19 & Ireland & 1809 & Ireland & Labourer \\
\hline Thompson & Corporal & 20 & Ireland & 1808 & Ireland & Labourer \\
\hline Toogood & Private & Unknown & England & 1804 & Ireland & Baker \\
\hline Tombs & Sergeant & 26 & England & 1805 & Ireland & Labourer \\
\hline Taylor & Corporal & 23 & England & 1804 & Ireland & Labourer \\
\hline Tierney & Private & Unknown & Unknown & 1805 & Unknown & Labourer \\
\hline Tonkinson & Private & Unknown & England & 1792 & Unknown & Toymaker \\
\hline Teesdale & Sergeant & 18 & England & 1803 & Ireland & Unknown \\
\hline Taylor & Private & Unknown & Unknown & 1809 & Unknown & Unknown \\
\hline Trethery & Corporal & 24 & England & 1798 & England & Unknown \\
\hline Taggerty & Private & Unknown & England & 1811 & England & Labourer \\
\hline Thompson & Private & 21 & Ireland & 1811 & Ireland & Weaver \\
\hline Thompson & Private & 17 & Ireland & 1812 & England & Labourer \\
\hline Tracey & Private & 18 & Ireland & 1812 & Ireland & Labourer \\
\hline Tozer & Private & 17 & England & 1812 & England & Labourer \\
\hline Toomy & Private & 20 & Ireland & 1812 & Ireland & Clerk \\
\hline Tunkings & Private & 21 & England & 1812 & England & Shoemaker \\
\hline Tenant & Private & 18 & England & 1812 & England & Labourer \\
\hline Tierney & Private & 21 & Ireland & 1812 & Ireland & Weaver \\
\hline Thomas & Private & 21 & England & 1812 & England & Rope maker \\
\hline Thomas & Private & Unknown & England & 1813 & England & Mason \\
\hline Thompson & Private & 20 & Ireland & 1813 & Ireland & Labourer \\
\hline Taylor & Private & 15 & England & 1813 & England & Carder \\
\hline Veasey & SM / QMS & 21 & England & 1806 & Ireland & Butcher \\
\hline Vasey & Corporal & 22 & England & 1804 & Ireland & Labourer \\
\hline Woodhouse & Private & 18 & England & 1793 & England & Weaver \\
\hline White & Private & 22 & England & 1805 & Ireland & Miner \\
\hline Way & Private & 21 & England & 1806 & Ireland & Weaver \\
\hline Wright & Private & 18 & England & 1806 & Ireland & Labourer \\
\hline Wintle & Private & 10 & England & 1806 & Ireland & Labourer \\
\hline Wiltshire & Sergeant & 44 & England & 1806 & Ireland & Clothdryer \\
\hline Wheeler & Private & 18 & England & 1807 & England & Labourer \\
\hline Wilson & Private & 19 & Ireland & 1808 & Ireland & Weaver \\
\hline Walsh & Private & 23 & Ireland & Unknown & England & Labourer \\
\hline Whaley & Sergeant & 23 & Ireland & 1807 & Ireland & Weaver \\
\hline Winwright & Private & 39 & England & 1796 & Spain & Brassmaker? \\
\hline Watson & Private & 20 & Ireland & 1811 & England & Servant \\
\hline Waters & Private & 20 & Ireland & 1805 & Ireland & Labourer \\
\hline Ward & Private & 19 & Ireland & 1811 & Ireland & Labourer \\
\hline
\end{tabular}


The Irish soldier in the British Army in the Peninsula Campaign

\begin{tabular}{|c|c|c|c|c|c|c|}
\hline Williams & Private & 17 & England & 1812 & England & Miner \\
\hline Webb & Private & 20 & England & 1812 & England & Labourer \\
\hline Worley & Private & 29 & England & 1812 & Ireland & Unknown \\
\hline West & Private & 28 & England & 1812 & England & Hatter \\
\hline Wethered & Private & 18 & Ireland & 1812 & Ireland & Weaver \\
\hline Whyte & Private & 16 & Ireland & 1812 & Ireland & Mason \\
\hline Watkins & Private & 28 & England & 1813 & England & Labourer \\
\hline Walsh & Private & 25 & Ireland & 1813 & Ireland & Labourer \\
\hline Waid & Private & 15 & Ireland & 1813 & Ireland & Labourer \\
\hline Williams & Private & 26 & England & 1810 & England & Cordwinder \\
\hline Worsley & Private & 19 & England & 1811 & England & Labourer \\
\hline Wilson & Private & 18 & Ireland & 1807 & Ireland & Weaver \\
\hline Webley & Private & 36 & England & 1796 & England & Labourer \\
\hline Withiell & Private & 26 & England & 1813 & England & Labourer \\
\hline Wright & Private & 15 & England & 1813 & England & Labourer \\
\hline Webster & Private & 24 & England & 1813 & England & Miner \\
\hline Windras & Private & 16 & England & 1813 & England & Weaver \\
\hline Weeks & Private & 27 & England & 1805 & Ireland & Labourer \\
\hline Watson & Private & 20 & Ireland & 1811 & Ireland & Labourer \\
\hline Wright & Private & 17 & Ireland & 1812 & Ireland & Labourer \\
\hline Winstanly & Private & 17 & England & Unknown & England & Nailer \\
\hline Winter & Private & 28 & Ireland & 1806 & Ireland & Weaver \\
\hline Wiggins & Private & 31 & Ireland & 1805 & Unknown & Mason \\
\hline Waldron & Private & 20 & England & 1817 & England & Labourer \\
\hline Gafaer & Private & 22 & England & 1817 & England & Groom \\
\hline Farrington & Private & 18 & England & 1815 & England & Weaver \\
\hline Edwards & Private & 21 & England & 1815 & England & Labourer \\
\hline Wellington & Private & 23 & England & 1815 & England & Labourer \\
\hline Lee & Private & 16 & England & 1815 & England & Labourer \\
\hline Edwards & Private & 20 & England & 1815 & England & Labourer \\
\hline Unch & Private & 17 & England & 1815 & England & Tailor \\
\hline Pally & Private & 20 & England & 1815 & England & Labourer \\
\hline Davis & Private & 21 & England & 1815 & England & Labourer \\
\hline Letten & Private & 28 & England & 1815 & England & Codwain \\
\hline Cahill & Private & 26 & Unknown & 1815 & Unknown & Unknown \\
\hline Mortimer & Private & 17 & Unknown & 1815 & Unknown & Unknown \\
\hline Pinkerton & Private & 24 & Unknown & 1815 & Unknown & Unknown \\
\hline Shawe & Private & 28 & England & 1815 & France & Labourer \\
\hline
\end{tabular}

Source: Description book 2/28 ${ }^{\text {th }}$ (North Gloucestershire) Regiment $1812-1817$, (TNA, WO 25/361). 


\section{APPENDIX 3 INFANTRY DIVISIONAL COMMANDERS' NATIONALITY - JANUARY}

\section{3}

\begin{tabular}{|c|c|c|c|c|c|c|c|c|c|}
\hline Division & $\begin{array}{c}\mathbf{1}^{\mathrm{st}} \\
\text { ('The } \\
\text { Gentleman's } \\
\text { Sons') }\end{array}$ & $\begin{array}{c}\mathbf{2}^{\text {nd }} \\
\text { ('Observing } \\
\text { Division') }\end{array}$ & $\begin{array}{c}\mathbf{3}^{\text {rd }} \\
\text { ('Fighting } \\
\text { Division') }\end{array}$ & 4th & $\begin{array}{c}\mathbf{5}^{\mathbf{t h}} \\
\text { ('The } \\
\text { Pioneers') }\end{array}$ & $\begin{array}{c}\mathbf{6}^{\mathbf{t h}} \\
\text { ('The } \\
\text { Marching } \\
\text { Division') }\end{array}$ & $\begin{array}{c}\mathbf{7}^{\mathbf{t h}} \\
\text { ('The } \\
\text { Mongrels') }\end{array}$ & $\begin{array}{l}\text { Light } \\
\text { ('The } \\
\text { Division') }\end{array}$ & $\begin{array}{l}\text { Portuguese } \\
\text { Division }\end{array}$ \\
\hline Commander & $\begin{array}{l}\text { Lt Gen Sir } \\
\text { William } \\
\text { Stewart }\end{array}$ & $\begin{array}{l}\text { Maj Gen Sir } \\
\text { Rowland } \\
\text { Hill }\end{array}$ & $\begin{array}{l}\text { Maj. Gen. Hon. } \\
\text { Edward } \\
\text { Pakenham } \\
\text { (Adjutant } \\
\text { General 10 May } \\
\text { 1813) }\end{array}$ & $\begin{array}{l}\text { Maj. Gen. } \\
\text { Sir } \\
\text { Galbraith } \\
\text { Lowry Cole }\end{array}$ & $\begin{array}{l}\text { Maj. Gen. John } \\
\text { Oswald (Maj. } \\
\text { Gen Andrew } \\
\text { Hay } \\
\text { commanded in } \\
\text { absence) }\end{array}$ & $\begin{array}{l}\text { Lt. Gen Sir } \\
\text { Henry } \\
\text { Clinton }\end{array}$ & $\begin{array}{c}\text { Maj. Gen } \\
\text { George, Earl of } \\
\text { Dalhousie }\end{array}$ & $\begin{array}{l}\text { Lt. Gen. Carl } \\
\text { von Alten }\end{array}$ & $\begin{array}{l}\text { Maj. Gen } \\
\text { John } \\
\text { Hamilton }\end{array}$ \\
\hline Nationality & Scottish & English & $\begin{array}{c}\text { Irish - } \\
\text { Westmeath }\end{array}$ & $\begin{array}{l}\text { Irish - } \\
\text { Dublin }\end{array}$ & $\begin{array}{c}\text { Oswald: } \\
\text { Scottish } \\
\text { Hay: Scottish }\end{array}$ & English & Scottish & German & $\begin{array}{l}\text { Irish - } \\
\text { Tyrone }\end{array}$ \\
\hline
\end{tabular}

Sources: Stuart Reid Wellington's army in the Peninsula 1809- 1814 (Oxford, 2004). Army List 1813 (TNA, WO65/63), Stuart Reid Wellington's officers (2 vols, Nottingham, 2010), Dictionary of Irish biography James McGuire and James Quinn, eds. (Cambridge, 2009) and J. A. Hall, A history of the Peninsular war vol. vIII the biographical dictionary of British officers killed and wounded, $1808-1814$ (8 vols, London, 1998). 


\section{APPENDIX 4 INFANTRY BRIGADE COMMANDERS' NATIONALITY - 1813}

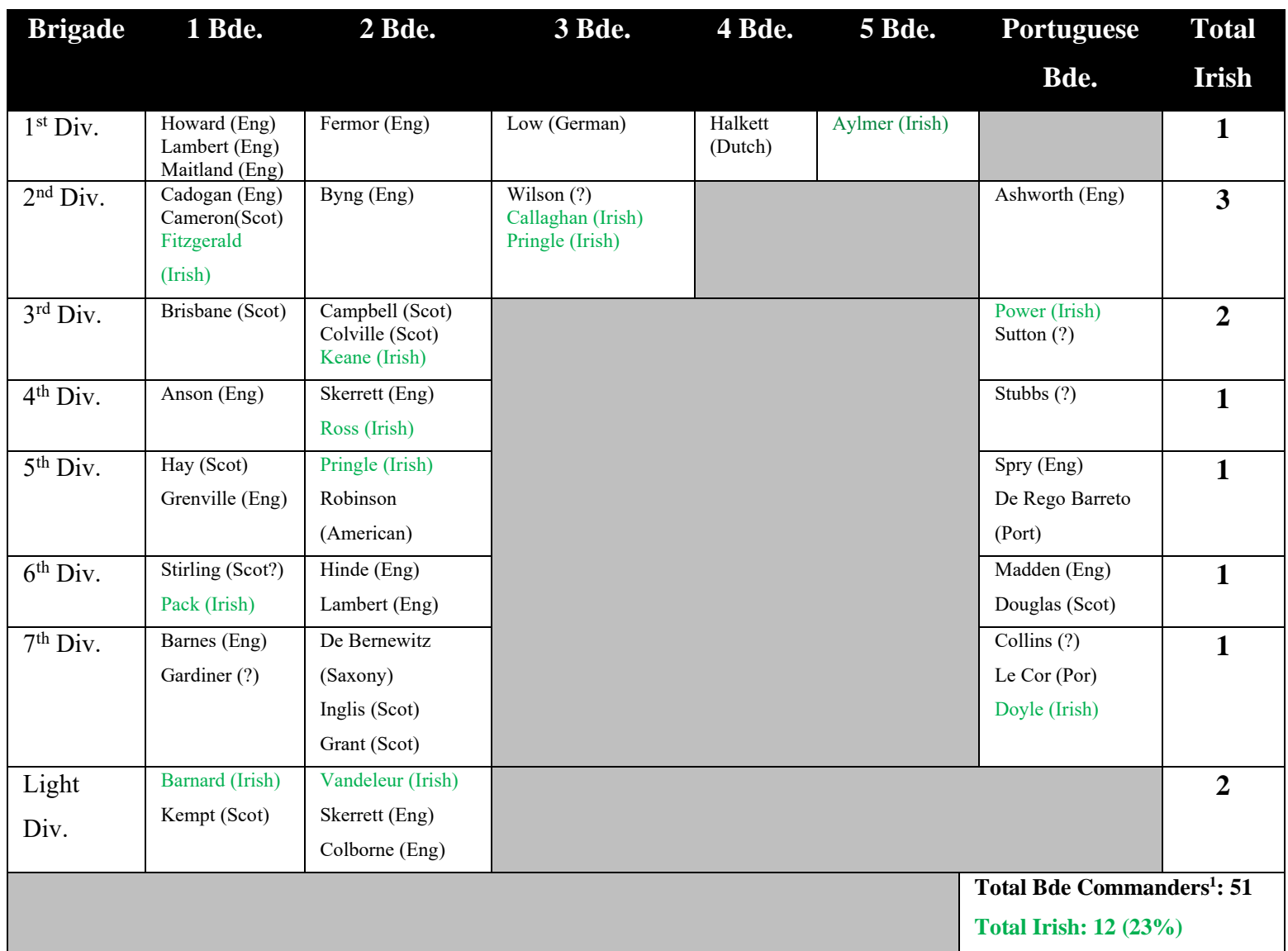

Note 1: The nationality of five brigade commanders could not be determined. It is probable that one (Collins) may be Irish.

Sources: Stuart Reid, Wellington's army in the Peninsula 1809- 1814 (Oxford, 2004) and Stuart Reid, Wellington's officers (2 vols, Nottingham, 2010). Ron McGuigan and Robert Burham, Wellington's brigade commanders - Peninsula and Waterloo (Barnsley, 2017). Army List 1813 (TNA, WO65/63), Dictionary of Irish biography, James McGuire and James Quinn, eds (Cambridge, 2009) and J. A. Hall, A History of the Peninsular war vol. vIII the biographical dictionary of British officers killed and wounded, 1808 -1814 (London, 1998). 
The Journal of Military History and Defence Studies

APPENDIX 5 CAVALRY BRIGADE COMMANDERS' NATIONALITY - 1813

\begin{tabular}{|c|c|c|c|c|c|c|c|c|}
\hline \multicolumn{9}{|c|}{ Cavalry Brigade Commanders } \\
\hline $\begin{array}{l}\text { Ponsonby } \\
\text { (Irish) }\end{array}$ & $\begin{array}{l}\text { Anson } \\
\text { (Eng) } \\
\text { Vandeleur } \\
\text { Irish) }\end{array}$ & $\begin{array}{l}\text { Alten } \\
\text { (Hanover) }\end{array}$ & $\begin{array}{l}\text { Von Bock } \\
\text { (Hanover ) } \\
\text { Bulow (German) }\end{array}$ & $\begin{array}{l}\text { Slade (Eng) } \\
\text { Fane (Eng ) }\end{array}$ & $\begin{array}{l}\text { Long (Eng ) } \\
\text { Grant (Scot) } \\
\text { Vivian Eng ) }\end{array}$ & $\begin{array}{l}\text { Rebow (Eng) } \\
\text { Hill (Eng) } \\
\text { O'Loughlin (Irish) }\end{array}$ & $\begin{array}{l}\text { Grant } \\
\text { (Scot) } \\
\text { Somerset } \\
\text { (Eng) }\end{array}$ & $\begin{array}{l}\text { Total: } 15 \\
\text { Total Irish: } \\
3(20 \%)\end{array}$ \\
\hline
\end{tabular}

Sources: Stuart Reid, Wellington's army in the Peninsula 1809- 1814 (Oxford, 2004). Stuart Reid, Wellington's officers (2 vols, Nottingham, 2010) and Ron McGuigan and Robert Burham, Wellington's brigade commanders - Peninsula and Waterloo

(Barnsley, 2017). Army List 1813 (TNA, WO65/63), Dictionary of Irish biography, James McGuire and James Quinn, eds. (Cambridge, 2009) and J. A. Hall, A history of the Peninsular war vol. vIII the biographical dictionary of British officers killed and wounded, 1808 -1814 (8 vols, London, 1998). 


\section{APPENDIX 6 SAMPLE OF REGIMENTAL OFFICERS' BY NATIONALITY - 52 ${ }^{\text {ND }}$ (OXFORDSHIRE) LIGHT INFANTRY 1813}

\begin{tabular}{|c|c|c|c|}
\hline Rank & Name & Nationality & Dead / Wounded \\
\hline $\mathrm{Lt} \mathrm{Col}$ & John Colborne & English & Wounded: Ciudad Rodrigo \\
\hline Maj & John P. Hunt & English & Wounded \\
\hline Maj & Charles Rowan & Irish & \\
\hline Maj & George T. Napier & English & Wounded: Ciudad Rodrigo \\
\hline Capt & William Chalmers & Scottish? & Wounded \\
\hline Capt & $\begin{array}{l}\text { William Rowan (brother of Charles } \\
\text { Rowan) }\end{array}$ & Irish & \\
\hline Capt & James Frederick Love & English & \\
\hline Capt & James M'Nair & Scottish & Wounded: Badajoz \\
\hline Capt & Henry Dawson & English & Dead \\
\hline $\mathrm{Lt}$ & John Cross & Irish & $\begin{array}{l}\text { Wounded : multiple } \\
\text { occasions }\end{array}$ \\
\hline $\mathrm{Lt}$ & John Dobbs & Irish & Wounded \\
\hline $\mathrm{Lt}$ & John Winterbottom & English & Wounded \\
\hline $\mathrm{Lt}$ & Sam. Dilman Pritchard & English & Wounded \\
\hline $\mathrm{Lt}$ & George Hall & English & Wounded: Badajoz \\
\hline $\mathrm{Lt}$ & George Gawler & English & Wounded: Badajoz \\
\hline $\mathrm{Lt}$ & George Whichcote & English? & Wounded: Badajoz \\
\hline Ensign & William Hunter & Scottish & $\begin{array}{l}\text { Wounded: Bidassoa and } \\
\text { Nive }\end{array}$ \\
\hline \multirow{3}{*}{\multicolumn{2}{|c|}{ Total officers in regiment: 85}} & English:10 & $59 \%$ \\
\hline & & \multicolumn{2}{|l|}{ Irish: 4} \\
\hline & & \multicolumn{2}{|l|}{ Scottish: 3} \\
\hline
\end{tabular}

Sources: Army List 1813 (TNA, WO65/63), Dictionary of Irish biography, James McGuire and James Quinn, eds (Cambridge, 2009) John A. Hall A history of the Peninsular war-vol. VIII The biographical dictionary of British officers killed and wounded, 1808 - 1814 (London, 1998), Mark Urban, Rifles - six years with Wellington's legendary sharpshooters (London, 2003), W.S. Moorsom (ed.), Historical record of the Fifty-second regiment (Oxfordshire light infantry) from the year 1755 to the year 1858 (London, 1860), John Dobbs, Recollections of an old $52^{\text {nd }}$ man (Waterford, 1859) and Oxford dictionary of national biographyhttp://www.oxforddnb.com.jproxy.nuim.ie/view/ (26 March 2018) 


\section{REFERENCES}

${ }^{1} \mathrm{H}$. J. Davies, Wellington's wars - the making of a military genius (London, 2012), chapters $5-8$.

2 Philip Haythornthwaite, The Peninsular war - the complete companion to the Iberian campaigns 1807-14 (London 2004).

${ }^{3}$ Wellington famously described his Peninsular army as 'probably the most complete machine for its numbers now existing in Europe' Stuart Reid, Wellington's army in the Peninsula 1809 -14 (Oxford, 2004), p.5.

${ }^{4}$ Peter Karsten, 'Irish soldiers in the British army, 1792 -1922: suborned or subordinate?' Journal of Social History, xvii, no.1 (Autumn, 1983), p.32.

${ }^{5}$ E. J. Coss, All for the King's shilling - the British soldier under Wellington, 1808-1814 (Oklahoma, 2010), p. 53 and Michael Chappell, Wellington's Peninsula regiments (1) - the Irish (London, 2003), p. 5.

${ }^{6}$ Michael Chappell, Wellington's Peninsula regiments (1) - the Irish (London, 2003).

7 K. B. Linch, 'The recruitment of the British army 1807 - 1815' (PhD thesis, University of Leeds, 2001).

8. See Peter Molloy, Ireland and the Waterloo Campaign 1815' in Journal of Military History and Defence Studies Vol 1. Issue 1 Jan 2020.

${ }^{9} 3 / 1^{\text {st }}$ (Royal Scots) Regiment of Foot (37 per cent Irish born) and $1 / 32^{\text {nd }}$ (Cornwall) Regiment of Foot (26.6 per cent Irish born). Peter Molloy, 'Ireland and the Waterloo campaign of $1815^{\prime}$ (MA thesis, NUI, Maynooth, 2011) p. 26.

${ }^{10}$ R. H. Paterson Pontius Pilate's bodyguard - a history of the First or the Royal Regiment of Foot. The Royal Scots (The Royal Regiment) volume one 1633 - 1918 (Edinburgh, 2001).

${ }^{11} 28^{\text {th }}$ (North Gloucestershire) Regiment of Foot (40 per cent Irish born) and the $94^{\text {th }}$ (The Scots Brigade) Regiment of Foot (51 per cent Irish born). Dan Harvey, A bloody day - The Irish at Waterloo (Cork, 2015) p. 9.

${ }^{12}$ The primary sources used by Coss provided key demographical information on NCOs and enlisted men such as age, place of birth and enlistment, previous employment or military service, promotion dates and certain discipline information. E.J. Coss, All for the King's shilling (Oklahoma, 2010).

${ }^{13}$ War Office records include regimental description books, inspection returns, monthly returns and records relating to courts martial. L. S. Challis, The Peninsula roll call (RUSI, 1948).

${ }^{14}$ Sir Charles William Oman work in the late $19^{\text {th }}$ and early $20^{\text {th }}$ centuries on the Peninsular war has been widely regarded as definitive in its accounts of the British army's operations in Portugal, Spain and France during the period 1808-14 and has been widely referenced by subsequent historians. In recent times certain of his findings have been disputed by other historians such as Paddy Griffith. Charles Oman, History of Wellington's army $1809-1814$ (London, 1912).

${ }^{15}$ Carole Divall, Inside the regiment: The officers and men of the $30^{\text {th }}$ Regiment during the Revolutionary and Napoleonic wars (Barnsley, 2011) p.36.

${ }^{16}$ Ron McGuigan and Robert Burnham, Wellington's brigade commanders - Peninsula and Waterloo (Barnsley, 2017) and Stuart Reid, Wellington's army in the Peninsula $1809-14$ (Oxford, 2004).

${ }^{17}$ W065/63 Annual Army List for 1813, National Archives, Kew.

${ }^{18} \mathrm{~J}$. A. Hall, $A$ history of the Peninsular war: The biographical dictionary of British officers killed and wounded, 1808 -1814 (8 vols, London, 1998), viii. 
${ }^{19}$ C.I. Pockett, 'Soldiers of the King: British soldiers and identity in the Peninsular war, 1808 - 1814' (MA thesis, Queens University, Ontario, 1998) p. 74 and Ciarán McDonnell, 'Irishmen in the British service during the French Revolutionary wars, 1793 - 1802' (PhD thesis, National University of Ireland, Maynooth, 2013).

${ }^{20}$ Robert Blakeney, A boy in the Peninsular war (ed) Julian Sturgis (London, 1899), John Dobbs, Recollections of an old $52^{\text {nd }}$ man (Waterford, 1859) and Harry Ross- Lewin, With the Thirty-Second in the Peninsular and other campaigns, (ed.) John Wardell (Dublin, 1904).

${ }^{21}$ The Test Acts acted as a religious test for Catholics and nonconformists who wished to hold public office and precluded them, inter alia, from holding the King's commission. The Act was seldom enforced after 1800 and was abolished as related to Catholics by 1829 . Divall identified one Catholic officer, Ensign William Sullivan, as a serving officer in the $30^{\text {th }}$ Cambridgeshire Regiment from 1803, Carole Divall Inside the regiment (Barnsley, 2011), p. 103.

${ }^{22}$ Edward Shils and Janowitz Morris, 'Cohesion and disintegration in the Wehrmacht in World War II', Public Opinion Quarterly (1948), pp xii and pp $280-315$.

${ }^{23}$ Michael Hughes, 'Vive la republique! Vive L'Empereur' Military culture and motivation in the armies of Napoleon $1803-1808$ (PhD thesis, University of Illinois, 2005) and E. J. Coss, All for the King's shilling (Oklahoma, 2012) pp 50-85.

${ }^{24}$ P.C. Bester and K.J. Stanz, 'The conceptualisation and measurement of combat readiness for peace support operations - an exploratory study', SA Journal of Industrial Psychology (2007), xxxiii, pp 68-78.

${ }^{25}$ Uzi Ben-Shalom and Yizhaq Benbenisty, 'Coping styles and combat motivation during operations: An IDF case study' in Armed Forces and Society, xLii (2016), pp 655-74.

${ }^{26}$ Nicholas Dunne-Lynch, 'Humour and defiance: Irish troops and their humour in the Peninsular war' in Journal of the Society for Army Historical, Lxxxv, no. 341 (Spring, 2007).

27 Nicholas Dunne-Lynch, The Irish in Wellington's Peninsular army - A debt neither acknowledged nor repaid'. in The Irish presence at the Cortes of Cadiz - politics, religion and war, (eds.) Hernan, Enrique, Garcia and Lario de Onate, M. Carmen (Madrid, 2014).

${ }^{28}$ Ciarán McDonnell, 'Irishmen in the British service during the French Revolutionary wars, 1793 - 1802' (PhD thesis, Maynooth 2013), p. 296.

29 Ibid, p. 297.

${ }^{30} \mathrm{~K}$. B. Linch, 'The recruitment of the British army 1807 - 1815' (PhD thesis, University of Leeds, 2001), p.34.

${ }^{31}$ The British army was to define 'casualty' as any manpower loss resulting from death, desertion or indeed discharge from the army. Ibid, p.22.

${ }^{32}$ WO1/946, E.B Littlehales to Welllesley-Pole, Chief Secretary for Ireland, 3 February 1811, including memorandum by Earl Liverpool.

${ }^{33}$ E. J. Coss, All for the King's shilling - the British soldier under Wellington $1808-1814$ (Oklahoma, 2010), p.53.

${ }^{34}$ K.B. Linch 'The recruitment of the British army $1807-1815^{\prime}$ (PhD thesis, University of Leeds, 2001), p. 262.

${ }^{35}$ E. J. Coss, All for the King's shilling (Oklahoma, 2010), p. 247.

${ }^{36} \mathrm{Ibid}$.

${ }^{37}$ E. J. Coss, All for the King's shilling (Oklahoma, 2010), p. 53.

$38 \mathrm{lbid}$.

${ }^{39}$ Carole Divall, Inside the regiment - The officers and men of the $30^{\text {th }}$ Regiment during the Revolutionary and Napoleonic Wars (Barnsley, 2011), p.2.

${ }^{40}$ Ibid p. 99.

${ }^{41}$ E. J. Coss, All for the King's shilling (Oklahoma, 2010), p. 246.

${ }^{42}$ E. J. Coss, All for the King's shilling (Oklahoma, 2010), p.60. 
${ }^{43}$ Coss identified a correlation between the rising cost of bread and increased enlistment rates for the British army during the period. Ibid p. 65-68.

${ }^{44}$ C. I. Pockett 'Soldiers of the King: British soldiers and identity in the Peninsular War, 1808 -1814' (M.A. thesis, Queen's University, Ontario, 1998), p. 72.

${ }^{45} \mathrm{Joep}$ Leerssen, Mere Irish and Fior - Ghael: studies in the idea of Irish nationality, its development and literary expression prior to the nineteenth century (Cork, 1996) p 376 as quoted in C. I. Pockett 'Soldiers of the King (MA thesis, Queen's University, Ontario, 1998), p.77.

${ }^{46}$ Although English, Harris kept his friend's secret until after his death demonstrating the close bonds that existed between Peninsular army soldiers irrespective of any national or even religious differences. Benjamin Harris, The compleat Rifleman Harris: the adventures of a soldier of the $95^{\text {th }}$ (Rifles) during the Peninsular campaign of the Napoleonic wars (2006), p.143.

${ }^{47}$ E. J. Coss, All for the King's shilling (Oklahoma, 2010), p. 248.

${ }^{48}$ Edward Costello, The adventures of a soldier of the $95^{\text {th }}$ (Rifles) in the Peninsular \& Waterloo campaigns of the Napoleonic wars (London, 1852), p. 123.

${ }^{49} \mathrm{Sir}$ Charles Oman, History of Wellington's army 1809 - 1814 (London, 1912), pp 213-14 and p. 248.

${ }^{50}$ Dunne-Lynch arrives at the same conclusion in his examination of the contribution of Irish soldiers to Wellington's army. Nicholas Dunne-Lynch, 'The Irish in Wellington's Peninsular army - A debt neither acknowledged nor repaid' in Enrique Hernan, Garcia and Lario de Onate, M. Carmen (eds) The Irish presence at the Cortes of Cadiz-politics, religion and war, (Madrid, 2014), pp 346-47.

${ }^{51}$ Lt. Peter Le Mesurier Through Spain with Wellington - the letters of Lieutenant Peter Le Mesurier of the 'Fighting Ninth', ed. Adrian Greenwood (Stroud, 2016), p. 87.

${ }^{52}$ Anon, Memoirs of a sergeant late in the Forty-third Light Infantry Regiment, previously to and during the Peninsular war; including an account of his conversion from the Popery to the Protestant religion (London, 1835). pp 12-14.

${ }^{53}$ William Grattan, The complete adventures in the Connaught Rangers: the $88^{\text {th }}$ Regiment during the Napoleonic wars by a serving officer (2009), p. 105.

${ }^{54}$ Darragh Cannon, 'Irish Catholic service and identity in the British armed forces 1793 1815' (M.L. thesis, NUI Maynooth), p. 134.

55 Ibid.

${ }^{56}$ Carole Divall, Inside the regiment (Barnsley, 2011), p. 132.

${ }^{57}$ Hansard, $1812-1813, \mathrm{XXI}, 1812,1249$ in K. B. Linch 'The recruitment of the British army $1807-1815^{\prime}$ (PhD thesis, University of Leeds, 2001), p. 182.

58 During the two battalion period of the $30^{\text {th }}$ Regiment $(1803-1817)$ both SMs were commissioned in 1810 in recognition of their services. Carole Divall, Inside the regiment (Barnsley, 2011), p. 80.

${ }^{59}$ Charles James, An universal dictionary (London, 1816), p.803.

${ }^{60}$ The description books do not indicate which rank either man achieved only stating rank as Sergeant-Major or Quarter Master Sergeant. Description book 2/28 ${ }^{\text {th }}$ (North Gloucestershire) Regiment 1812 - 1817, (TNA WO 25/361).

${ }^{61}$ William Moorsom, Historical record of the Fifty-second Regiment (Oxfordshire Light Infantry) (London, 1860), p.76.

${ }^{62}$ Anon, Memoirs of a Sergeant late in the Forty-third Light Infantry Regiment (London, 1835), p. 68.

${ }^{63}$ Carole Divall, Inside the regiment (Barnsley, 2011), p. 89.

${ }^{64} \mathrm{lbid}, \mathrm{pp} 84-88$.

${ }^{65}$ Divall, Carole, Inside the regiment (Barnsley, 2011), p. 36. 
${ }^{66}$ Research into discipline during the First World War found that while Irish soldiers faced courts martial more often than English, Scottish or Welsh soldiers the offences they were charged with would have generally been dealt with by a commanding officer in the case of English or other soldiers. Timothy Bowman, Irish regiments in the Great War - discipline and morale (Manchester, 2003), p. 202-03.

${ }^{67}$ Charles O'Neill, The military adventures of Charles O'Neill (London, 2015), pp 46-47.

68 Ibid, p.266

${ }^{69}$ John Duncan Ellis, 'Recruitment and promotion in the Napoleonic British army: a study of the $28^{\text {th }}$ (North Gloucestershire) Regiment, an English regiment at Waterloo' (BA thesis, Cheltenham and Gloucester College, 1999), pp. 15 -24.

70 Letter from Sir Edward Baker Littlehales to William Wellesley-Pole, File 31P, NUI Maynooth Library, Ireland.

${ }^{71}$ John Keegan, Face of battle (London, 2014), p.116 and Philip Haythornthwaite, The armies of Wellington (London, 1994), pp $123-25$.

72 Mike Chappell, Wellingtons Peninsula regiments (1) - The Irish (London, 2003), DunneLynch, Nicholas, 'The Irish in Wellington's Peninsular army - A debt neither acknowledged nor repaid'. in 'The Irish Presence at the Cortes of Cadiz, ed. Hernan, Enrique, Garcia and Lario de Onate, M. Carmen (Madrid, 2014) and Peter Molloy, 'Ireland and the Waterloo campaign 1815' (MA thesis, NUI, Maynooth 2003).

${ }^{73}$ C. I. Pockett 'Soldiers of the King: British soldiers and identity in the Peninsular war, 1808 -1814' (M.A. thesis, Queen's University, Ontario, 1998), p.68.

${ }^{74}$ Ciarán McDonnell, 'Irishmen in the British service during the French Revolutionary wars, 1793 - 1802' (PhD thesis, NUI, Maynooth 2013), p. 5.

$75 \mathrm{Ibid}$.

${ }^{76}$ Captain Ross-Lewin from Ross Hill in Co. Clare served with the $32^{\text {nd }}$ (Cornwall) Regiment. Harry Ross-Lewin, With the Thirty-second in the Peninsular and other campaigns, ed. John Wardell (Dublin, 1848), p. 36 and p. 54.

${ }_{77}^{7}$ Thomas Bartlett, Ireland a history (Cambridge, 2010), pp 153-58.

78 J.T. Leerson, 'Anglo-Irish patriotism and its European context: notes towards a reassessment' in Eighteenth-century Ireland/ Iris an dá chultúr, iii (1988), pp 7-24, at p.7; Foster, Modern Ireland, p. 248.

${ }^{79}$ Brabazon Ponsonby, Earl of Bessborough consolidated the power and future influence of the family among the Protestant Ascendancy in Ireland during the 1720's. His son John was to become Commissioner of the Irish Revenue Board and under his control was able to dispense hundreds of small employments building a strong power base and formidable parliamentary following. Thomas Bartlett, Ireland a history (Cambridge, 2010), pp 151.

${ }^{80}$ Captain Harry Ross-Lewin served in the $32^{\text {nd }}$ (Cornwall) Regiment from 1795 and was an experienced officer, West Indies (1793-98), Copenhagen (1807) and Walcheren (1809), prior to his service in the Peninsula. His two brothers also served in the Peninsula: Lieutenant Thomas Ross-Lewin wounded in the Pyrenees on 30 July 1813 while serving with the $32^{\text {nd }}$ (Cornwall) Regiment and Lieutenant Edward Ross-Lewin killed storming the fortress of San Sebastien with the $9^{\text {th }}$ (East Norfolk) Regiment on 31 August 1813. Harry Ross-Lewin, With the Thirty-second ed. John Wardell (Dublin, 1848) and J. A. Hall, A History of the Peninsular war vol. viii the biographical dictionary of British officers killed and wounded, $1808-1814$ (London, 1998), p. 501.

${ }^{81}$ Ian Worthington, 'Antecedent education and officer recruitment: the origins and early development of the public school - army relationship.' Military Affairs, vol. xLi, no.4 (December, 1977), pp 183 -89.

${ }^{82}$ Carole Divall, Inside the regiment - the officers and men of the $30^{\text {th }}$ Regiment during the Revolutionary and Napoleonic wars (Barnsley, 2011), p.102. 
${ }^{83}$ Captain Richard Robinson, $1^{\text {st }}$ Royal Scots Guards. Letters written from Spain during the Peninsular war, 1809 - 1811, to his father Archdeacon of Armagh and his uncle Wm. Knox Lord Bishop of Derry), MS 42,243 (National Library of Ireland).

${ }^{84}$ Stuart Reid, Wellington's army in the Peninsula 1809 - 14 (Oxford, 2004), p. 68.

85 La Touche's family of Huguenot descent established La Touche Bank in Dublin, which ultimately became Bank of Ireland one of the two pillar banks in Ireland today. LaTouche House stands at the heart of the Irish Financial Services Centre in Dublin today. Divall, Carole, Inside the regiment (Barnsley, 2011), p. 102.

${ }^{86}$ Edward Macready, The journal and opinions of Edward Nevil Macready, $30^{\text {th }}$ Regiment of Foot, 1814 -1830. (NAM - 1968-07-209-1).

87 John Dobbs, Recollections of an old $52^{\text {nd }}$ man (Waterford, 1859).

88 The Test Acts acted as a religious test for Catholics and nonconformists who wished to hold public office and precluded them, inter alia, holding the King's Commission. The Act was seldom enforced after 1800 and was abolished as related to Catholics by 1829. Irish Catholic officers were allowed to serve within the ranks of the Irish militia and yeomanry. Arthur James Plunkett, Earl of Fingall commanded the Skreen Cavalry Yeomanry and had served in the Royal Meath Militia, taking part in the suppression of the 1798 rebellion. Fingall was also a noted Catholic relief campaigner described as 'a zealous and faithful subject of the Crown'. in Ciarán McDonnell, 'Irishmen in the British service during the French Revolutionary wars, 1793 - 1802' (PhD thesis, NUI, Maynooth 2013), p. 214.

${ }^{89}$ Carole Divall, Inside the regiment (Barnsley, 2011), p. 103.

${ }^{90} \mathrm{Ibid}$, p. 103.

${ }^{91}$ Some accounts list $\mathrm{O}^{\prime}$ Hare as being commissioned from the ranks in the $69^{\text {th }}$ Regiment although this was not entirely correct. Mark Urban, Rifles - six years with Wellington's legendary sharpshooters (London, 2003).

${ }^{92}$ Charles James, Officers' companion, vol 1, pp xii - xiii.

${ }^{93} \mathrm{~J}$. E. Cookson, 'Regimental worlds: interpreting the experiences of British soldiers during the Napoleonic wars' in Alan Forrest, Karen Hagemann and Jane Rendall Soldiers, citizens and civilians: experiences and perceptions of the Revolutionary and Napoleonic wars $1790-$ 1820 (London, 2009), pp23 - 43. Based on Inspection returns 1813 (TNA, WO27/90/102, 121-123).

94 Stuart Reid, Wellington's army in the Peninsula 1809 - 14 (Oxford, 2004).

${ }^{95}$ Rory Muir, Robert Burnham, Howie Muir and Ron McGuigan, Inside Wellington's Peninsular army (Barnsley, 2014), p. 195.

${ }^{96}$ Oxford Dictionary of National Biography, Hamilton, Sir John http://www.oxforddnb.com.jproxy.nuim.ie/view/ (26 March 2018) and London Gazette 13 July 1813, p.5 No.16752.

${ }^{97}$ Throughout the nineteenth and into the twentieth century the Vandeleurs continued to serve in the British army. Brigadier John Ormsby Evelyn (Joe) Vandeleur was an Irish Guards officer who led the breakthrough of XXX Corps during Montgomery's daring but ultimately doomed Operation Market Garden in September 1944. Cornelius Ryan, A bridge too far (London, 1982), p.147.

${ }^{98}$ Harry Smith, The autobiography of Sir Harry Smith 1787 - 1819: a classic story of love and war (London 1999), p.51.

${ }^{99}$ Ron McGuigan and Robert Burnham, Wellington's brigade commanders - Peninsula and Waterloo (Barnsley, 2017), p ix.

${ }^{100}$ The battle of Maida fought in Sicily is notable as the first instance of French columns of attack being defeated by British line and platoon fire, which was to be used to deadly effect in the Peninsula campaign. B. Smyth History of the XX Regiment: $1688-1888$ (1889, London), p. 120. 
${ }^{101}$ Power was also an Irish officer. Ron McGuigan and Robert Burnham, Wellington's brigade commanders (Barnsley, 2017), p. 256.

102 James McGuire and James Quinn, eds. Dictionary of Irish biography http://www.dib.org (26 March 2018).

${ }^{103}$ William Wheeler, The letters of Private Wheeler, 1809 - 1828, ed. Captain B. H. Liddell Hart (London, 1951), p. 236 -37.

${ }^{104}$ General 'Bob' Craufurd, commander of the Light Brigade had placed his brigade in an isolated position on the enemy side of the Coa river with the intention of drawing French forces to battle. On 24 July 1810, Marshal Ney and 25,000 French soldiers quickly overwhelmed Craufurd's picket line forcing the 4,000 British to retreat. The battle degenerated into a series on smaller engagements as each regiment sought to extricate itself to the far side of the river. It was the actions of the individual regiments which prevented a defeat turning into a rout. Although Wellington reprimanded Craufurd for his rare lapse of judgement Craufurd was later promoted and the Light Brigade expanded into a division. Mark Urban, Rifles - six years with Wellington's legendary sharpshooters (London, 2003), pp 55-65 and Anon, Memoirs of a sergeant late in the Forty-third Light Infantry Regiment, previously to and during the Peninsular war; including an account of his conversion from the popery to the protestant religion (London, 1835), p. 91.

105 Description books $52^{\text {nd }}$ Regiment Light Infantry $1803-1808$, (TNA, WO25/405 and WO 25/406).

${ }^{106}$ Army List 1813 (TNA, WO65/63) and William Moorsom, Historical record of the Fiftysecond regiment (London, 1860).

107 Captain William Rowan, brother of Major Charles Rowan, also served with the $52^{\text {nd }}$ (Oxfordshire) Light Infantry and subsequently became Lieutenant Governor of Upper Canada. James McGuire and James Quinn, eds. Dictionary of Irish biography http://www.dib.org (26 March 2018).

${ }^{108}$ R.J. Smith, 'John Bull's proconsuls: military officers who administered the British Empire 1815 - 1840' (PhD thesis, Kansas State University, 2008).

${ }^{109}$ Charles Esdaile, 'Wellington triumphant: an analysis of British battlefield invincibility in Spain and Portugal, 1808 - 1814' (unpublished), quoted in E. J. Coss, All for the King's shilling - the British soldier under Wellington, 1808 - 1815 (Oklahoma, 2012), p. 154.

110 Throughout the Peninsula campaign and even during the Waterloo campaign, Wellington had insufficient artillery. Artillery ammunition resupply was also a recurring problem further limiting the firepower of this key battle winning weapon. In addition, while his cavalry were proficient at outpost, picket and scouting roles it was beset with command and control issues to be fully effective as a battlefield tool and indeed the terrain in Spain, particularly north of the Douro River was unsuitable to large scale battlefield deployment of cavalry so familiar on the central European battlefields. Michael Glover, The Peninsular war, 1807-1814 - a concise military history (London, 2001), p. 36.

${ }^{111}$ French General Foy who fought in the Peninsula stated that Wellington's infantry were the best portion of the British army comparing them to the Roman triarii. General Maximilien Sébastien Foy History of the war in the Peninsula, under Napoleon (London, 1827), pp 196-97.

${ }^{112}$ Charles Oman delivered a series of lectures at the Royal Artillery Institution in 1907 where he presented his findings based on the testimony of British eyewitnesses. He subsequently published his lectures in the Journal of the Royal Artillery Institute 34 (1907). He also published his views in History of Wellington's army 1809 - 1814 (London, 1913), pp 88-89. Jac Weller also attributes the defeat of the French to repeated volley fire delivered at long, medium and short range. Jac Weller, Wellington in the Peninsula, 1808-1814 (Barnsley, 1992), p. 42. 
113 Paddy Griffith, Forward into battle: fighting tactics from Waterloo to Vietnam (Chichester, 1981), pp 12-42 and General B.P. Hughes, Firepower: weapons effectiveness on the battlefield, 1630 - 1850 (London, 1974), pp 59-65.

${ }^{114}$ Brent Nosworthy, Battle tactics of Napoleon and his enemies (London, 1995), pp 219-44. $115 \mathrm{Ibid}, \mathrm{pp} 35-48$.

${ }^{116}$ E. J. Coss, All for the King's shilling - the British soldier under Wellington, 1808 - 1815 (Oklahoma, 2012), pp 162-63 and Philip Haythornthwaite, British Napoleonic infantry tactics $1792-1815$ (Oxford, 2008), pp $45-48$.

117 Baron Larrey, Napoleon's surgeon general, estimated that bayonet wounds only accounted for approx. 2 per cent of all wounds based on the French battles of 1807. Mark Adkin, The Waterloo companion (London, 2001), p. 168.

${ }^{118}$ Brent Nosworthy, Battle tactics of Napoleon and his enemies (London, 1995), p. 228.

119 Marquis de Chambray 'Reflections on the infantry of our days', in Philosophie de la Guerre, translation in the United Services Journal (3 vols, 1834), ii, pp 505-07.

120 The $88^{\text {th }}$ (Connaught Rangers) acted as Wellington's shock troops in numerous engagements delivering bayonet charges at Bussaco (1810), Fuentes de Onoro (1811) and Salamanca (1812) and storming the fortress town of Badajoz (1812). Richard Holmes Redcoat- the British soldier in the age of horse and musket (London, 2002), pp 59-61.

${ }^{121}$ Thomas Bartlett and Keith Jeffery, 'An Irish military tradition?' in Thomas Bartlett and Keith Jeffery (eds), A military history of Ireland, (New York, 1996), pp 1-25.

122 William Wheeler, The letters of Private Wheeler, 1809 - 1828, ed. Captain B. H. Liddell Hart (London, 1951), p. 113.

${ }^{123}$ William Grattan, The complete adventures in the Connaught Rangers: The $88^{\text {th }}$ Regiment during the Napoleonic wars by a serving officer (2009), p. 105.

${ }^{124} \mathrm{E}$. J. Coss, All for the King's shilling (Oklahoma, 2012), pp 191-210.

${ }^{125}$ Every six to eight soldiers were issued a large cooking pot or camp kettle, into which all of the group's individual rations would be put and a communal meal prepared each evening. The group would have also shared whatever extra rations each individual might had acquired. Such close bonding produced a highly integrated group whose inter dependencies were only increased through the need to collectively support each other in order to survive the harsh realities of early nineteenth century campaigning.

126 Edward Costello, The adventures of a soldier of the 95 ${ }^{\text {th }}$ (Rifles) in the Peninsular \& Waterloo campaigns of the Napoleonic wars ( $2^{\text {nd }}$ ed., London, 1852), p. 194.

127 Samuel Stouffer, Arthur Lumsdaine, Marion Lumsdaine, Robin Williams, M.I. Brewster Smith, Irving Janis, Shirley Star and Leonard Cottrell, 'The American soldier: combat and its aftermath', Studies in social psychology in World War II (3 vols, Princeton, 1949 - 1950), ii pp 130-31.

${ }^{128}$ Edward Costello, The adventures of a soldier of the $95^{\text {th }}$ ( $2^{\text {nd }}$ ed., London, 1852), pp 6465.

${ }^{129}$ Edward Costello, The adventures of a soldier of the 95 ${ }^{\text {th }}$ (Rifles), p. 160.

${ }^{130}$ Benjamin Harris, The compleat Rifleman Harris: The adventures of a soldier of the $95^{\text {th }}$ (Rifles) during the Peninsular campaign of the Napoleonic wars (2006), pp 126-29.

${ }^{131}$ Richard Holmes, Redcoat (London, 2002), pp 62-63.

132 Benjamin Harris, The compleat Rifleman Harris (2006) pp86-88. The three brothers, John, Mike and Peter Hart survived the retreat and the resulting battle to be embarked from the beach at Corunna and transported back to England. However, one was to die during the subsequent Walcheren campaign (1809) while the remaining brothers 'although they lived to return, were never worth a rush afterwards'.

133 Nicholas Dunne-Lynch, 'Humour and defiance: Irish troops and their humour in the Peninsular war', in Journal of the Society for Army Historical Research, Lxxxv, no. 341 (Spring, 2007), pp 62-78. 
${ }^{134}$ E. J. Coss, All for the King's shilling (Oklahoma, 2012), p.196.

${ }^{135}$ Edward Shils and Janowitz Morris, 'Cohesion and disintegration in the Wehrmacht in World War II' Public Opinion Quarterly xii (1948), p. 285.

136 Stouffer et al 'The American soldier: combat and its aftermath', Studies in social psychology in World War 11 (3 vols, Princeton, 1949 - 1950), ii, pp 174-75, pp 179-81.

137 Uzi Ben-Shalom and Yizhaq Benbenisty, 'Coping styles and combat motivation during operations: an IDF case study' Armed Forces and Society (vol. 42(4), 2016), pp 655-74.

${ }^{138}$ E. J. Coss, All for the King's shilling (Oklahoma, 2012), pp 207-10.

139 Civilian offenders were liable to hanging, whipping and transportation for relatively minor offences under the Bloody Code, the name given to the English system of criminal law from 1688 to 1815 . There were over 200 capital offences listed in 1800 . Richard Holmes places military discipline in the broader social context that British soldiers would have been familiar with. In doing so we can more fully appreciate how military discipline as practiced by the British army would not have caused a misalignment with the values of the primary group. Richard Holmes, Redcoat (London, 2002), pp 319- 21.

${ }_{140}$ Paddy Griffith, The art of war of revolutionary France 1789-1802 (London, 1998), pp 20734.

${ }^{141}$ David Gates, The British light infantry arm c.1790 - 1815 (London, 1987), p. 26.

142 Ibid. Lt. Gen. Sir William Stewart, The Cumloden Papers: The Correspondence of Lt Gen Sir William Stewart (Edinburgh, 1871) p. 23 and NLS MSS.3835 (Melville Papers f.181: Hints on improving the military system of Great Britain, by Sir John Sinclair). Stewart had served with Britain's allies Austria and Russian during the 1799 campaign in Italy and it was probably here that he first encountered Croat and Tyrolese light infantry troops in action. On his return he advocated for a permanent light infantry force for the British army and by 1800 was in command of the experimental 'Corps of Riflemen', the forerunners of the $95^{\text {th }}$ Rifles. In 1810 he was sent to the Peninsula as a Major General eventually commanding Wellington's Second Division where his performance left a lot to be desired. At the battle of Albuera in May 1811 three of his regiments were massacred by French cavalry following an ill judged order to one of his brigade commanders Sir John Colborne. Stewart served until the end of the Peninsula campaign and saw no further active service dying in 1827. His influence and expertise in training and handling light infantry is best summed up by Glover who wrote 'As a battalion commander, Stewart was surpassed only by Moore; as a general he was a menace' Michael Glover, The Peninsular war, 1807-1814 (London, 2001), p. 161. 143 TNA, WO 30/72, Notes sur les chasseurs, summer 1803. General Dumouriez was a former French general and émigré who arrived in Britain in 1803 after falling foul of the political intrigues associated with the Revolution. Dumouriez led the French army to victory against the Austrians at the critical battle of Jemappes (1792) saving the nascent French Revolution. In England he acted as an advisor to the War Office and wrote a plan of defence for southern England against the expected French invasion. Dumouriez was considered an expert on the use of light infantry and had in-depth knowledge of the French use of such troops. He had influence within the British military establishment and his views would certainly have been considered especially among those tasked with establishing the new light infantry units such as Stewart and Moore. His Notes sur les Chasseurs contain his views on how England should use and develop its light infantry to repulse the expected French invasion.

${ }^{144}$ Mike Chappell, Wellington's Peninsula regiments (2) The light infantry (Oxford, 2004), p. 8.

${ }^{145}$ W.S. Moorsom (ed.), Historical record of the Fifty-second regiment (Oxfordshire light infantry) from the year 1755 to the year 1858 (London, 1860), pp 62-63. As Napoleon gained more control of mainland Europe the ability to recruit mercenaries from the German states for light infantry was greatly reduced. 
${ }^{146}$ Lt. Gen. Sir John Moore $(1769-1809)$ is considered the father of the British light infantry. He was to assume command of a brigade of infantry including the $52^{\text {nd }}$ Regiment in 1803 and commenced training them in the light infantry role. Moore used innovative methods in his approach creating the British army's first permanent light infantry units. His template for light infantry training was used by the army in the decades to come. A number of famous figures and personalities from the Peninsula campaign were trained under his tenure at Shorncliffe including Lt. Col. William Napier (later renowned Peninsular war historian), his brother George Napier and Sir John Colborne. He assumed command of all British forces in the Peninsula in 1808 following the recall of Sir Harry Burrard, Sir Hew Dalrymple and Sir Arthur Wellesley to face the Cintra inquiry. His subsequent retreat to the embarkation ports at Vigo and Corunna has gone down in British military legend. Although defeating the pursuing French army outside Corunna it was a pyrrhic victory for the British army as Moore was mortally wounded. A number of historians considered him a potential claimant to Wellington's position in the pantheon of British military commanders had he lived.

147 In July 1803 the $43^{\text {nd }}$ (Monmouthshire) Regiment of Foot was likewise converted to a light infantry regiment. By April 1804 the $52^{\text {nd }}$ Regiment was authorised to raise a second battalion and by the end of the year the $95^{\text {th }}$ (Rifles) Regiment was also at Shorncliffe.

148 The $52^{\text {nd }}$ (Oxfordshire) Regiment was stationed throughout at Shorncliffe as it was undergoing specialised training and acting as a stand by force in case of a French invasion along the south coast of England.

${ }^{149}$ W.S. Moorsom ed. Historical record of the fifty-second regiment (London, 1860), p. 69.

${ }^{150}$ Each regimental description book contains a column entitled 'Place of Enlistment'. The $52^{\text {nd }}$ regiment's description books do not have this column completed in a number of instances so a full statistical analysis cannot be completed. However, from the number of individuals who had their place of enlistment entered the above findings are clearly evident. Joseph Dobbs was mentioned in dispatches by Wellington for his action at Villa Formosa in May 1811. Dobbs was ultimately killed in the storming of Ciudad Rodrigo as part of the forlorn hope on 19 January 1812 while Napier lost his right arm leading the Light Division's storming party. Description book, 1/52 ${ }^{\text {nd }}$ Regiment of Foot 1803, Description book $52^{\text {nd }}$ Regiment Light Infantry $1803-1808$, (TNA, WO25/405 and WO 25/406). J. A. Hall, $A$ history of the Peninsular war - The biographical dictionary of British officers killed and wounded, 1808 - 1814 (8 vols, London, 1998), viii, pp 168-69 and pp 429-30.

${ }^{151}$ Stewart's views and subsequent impact on recruiting of Irish and Scottish recruits to the $95^{\text {th }}$ Rifles is discussed by Mark Urban in Rifles - Six years with Wellington's legendary sharpshooters (London, 2003), pp 185-86.

${ }^{152}$ Anon, A manual for volunteer corps of Infantry (London, 1803), pp 30-33.

153 Stuart Hadaway, Rifleman Thomas Plunkett: a pattern for the battalion' (http://www.napoleon- series.org/research/biographies/c plunkett.html) (20 February 2018)

${ }^{154}$ The table above provides as close as possible an indication of the extent of Irish soldiers serving in the Light Division during combat operations in the Peninsula. Primary and secondary sources on actual percentages of Irish soldiers were selected from periods as close as possible to 1811. Based on these findings Irish soldiers were filling the ranks of this elite division in significant numbers.

${ }^{155} \mathrm{Jac}$ Weller, Wellington in the Peninsula (Barnsley, 1992), p. 158.

156 The Light Division comprised both battalions of the $52^{\text {nd }}$ (Oxfordshire) Light Infantry as well the $1 / 43^{\text {rd }}$ (Monmouthshire) Regiment, $1 / 95^{\text {th }}$ Riles with elements of the $2 / 95^{\text {th }}$ and the $1^{\text {st }}$ and $3 r^{\text {d }}$ Portuguese Cacadores. Jac Weller, Wellington in the Peninsula (Barnsley, 1992), p. 162. 
157 Mark Urban, Rifles - six years with Wellington's legendary sharpshooters (London, 2003), p. 118.

158 Jac Weller, Wellington in the Peninsula (Barnsley, 1992), p. 163. Weller cites Oman's estimate of 44 casualties while Fortescue estimates 67 casualties.

${ }^{159}$ Charles Oman, A history of the Peninsular war December 1810 - December 1811 (7 vols, Oxford, 1911), iv, p. 326.

160 Philip Haythornthwaite, British light infantry and rifle tactics of the Napoleonic wars (Oxford, 2016), p. 59.

${ }^{161}$ Carole Divall, Inside the regiment - the officers and men of the $30^{\text {th }}$ Regiment during the Revolutionary and Napoleonic wars (Barnsley 2014), p. 99.

${ }^{162}$ C.I. Pockett 'Soldiers of the King: British soldiers and identity in the Peninsular War, 1808 - 1814' (MA thesis, Queens University, Ontario, 1998), p. ii

${ }^{163}$ Nosworthy discusses this ability of the British army to merge the various national characteristics into a combat effective force. Brent Nosworthy, Battle tactics of Napoleon and his enemies (London, 1995), p. 230.

${ }^{164}$ Robert Blakeney, A boy in the Peninsular war, ed. Julian Sturgis (London, 1899), p. 321.

${ }^{165}$ E. J. Coss, All for the King's shilling - the British soldier under Wellington $1808-1814$

(Oklahoma, 2010) and K.B. Linch 'The recruitment of the British army $1807-1815^{\prime}$ (PhD thesis, University of Leeds, 2001), pp 172-78. 